This report was prepared as an account of work sponsored by an agency of the United States Government. Neither the United States Government nor any agency thereof, nor any of their employees, makes any warranty, express or implied, or assumes any legal liability or responsibility for the accuracy, completeness, or usefulness of any information, apparatus, product, or process disclosed, or represents that its use would not infringe privately owned rights. Reference herein to any specific commercial product, process, or service by trade name, trademark, manufacturer, or otherwise does not necessarily constitute or imply its endorsement, recommendation, or favoring by the United States Government or any agency thereof. The views and opinions of authors expressed herein do not necessarily state or reflect those of the United States Government or any agency thereof.

\title{
Estimating Costs of \\ Low-Level Radioactive Waste Disposal Alternatives for the Commonwealth of Massachusetts
}

Published February 1994

\author{
Idaho National Engineering Laboratory \\ National Low-Level Waste Management Program \\ EG\&G Idaho, Inc. \\ Idaho Falls, Idaho $\mathbf{8 3 4 1 5}$
}

drepared for the

U.S. Department of Energy

Office of Environmental Restoration and Waste Management

Under DOE Idaho Operations Office

Contract DE-AC07-76ID01570 


\section{ABSTRACT}

This report was prepared for the Commonwealth of Massachusetts by the Idaho National Engineering Laboratory, National Low-Level Waste Management Program. It presents planning life-cycle cost (PLCC) estimates for four sizes of in-state low-level radioactive waste (LLRW) disposal facilities. These PLCC estimates include preoperational and operational expenditures, all support facilities, materials, labor, closure costs, and long-term institutional care and monitoring costs.

It is intended that this :aport be used as a broad decision making tool for evaluating one of the several complex factors that must be examined when deciding between various LLRW management options - relative costs. Because the underlying assumptions of these analyses will change as the Board decides how it will manage Massachusett's waste and the specific characteristics any disposal facility will have, the results of this study are not absolute and should only be used to compare the relative costs of the options presented.

The disposal technology selected for this analysis is aboveground earth-mounded vaults. These vaults are reinforced concrete structures where low-level waste is emplaced and later covered with a multi-layered earthen cap. The "base case" PLCC estimate was derived from a preliminary feasibility design developed for the Illinois Low-Level Radioactive Waste Disposal Facility. This PLCC report describes facility operations and details the procedure used to develop the base case PLCC estimate for each facility component and size. Sensitivity analyses were performed on the base case PLCC estimate by varying several factors to determine their influences upon the unit disposal costs. The report presents the results of the sensitivity analyses for the five most significant cost factors. 


\section{ACKNOWLEDGEMENTS}

The authors would like to acknowledge the efforts of the technical contributors to this report: Fred Feizollahi, Mike Godwin, Catherine Slater, and Bruce Stevens of Environmental Services Division, Morrison Knudsen Corporation; technical guidance provided by David Shropshire and Paul Smith of EG\&G, Idaho, Inc.; and policy guidance provided by Carol Amick and Paul Mayo from the Commonwealth of Massachusetts LowLevel Radioactive Waste Management Board whose efforts made this study possible. 


\section{EXECUTIVE SUMMARY}

Planning life-cycle cost (PLCC) estimates for conceptual designs of low-level radioactive waste (LLRW) disposal facilities for the Commonwealth of Massachusetts are based on the preliminary feasibility design for the Illinois Low-Level Radioactive Waste Disposal Facility for the Central Midwest Compact (the states of Illinois and Kentucky). PLCC estimates for four sizes of in-state disposal facilities were evaluated (small, medium, large, and extra-large). PLCCs were estimated for five areas of operation: (1) preoperations - including land acquisition, site selection and characterization, and initial capital improvements; (2) operations - including annual utilities, materials and labor costs; (3) closure - including decommissioning of the facility and completion of the disposal vaults; (4) post-closure - including institutional care and monitoring; and (5) community benefits and taxes. These PLCC estimates are broad-based in nature and should be used only as a decision making tool. It should be remembered that the assumptions underlying these analyses will change as the Board decides how it will manage Massachusett's waste and the specific characteristics any disposal facility will have. Therefore, the results of this study are not absolute and should only be used to compare the relative costs of the options presented.

Sensitivity analyses were performed on PLCC estimates for each size of facility by varying several parameters. The labor rates, capital costs, staffing, preoperational costs, and material costs were selected to represent changes due to uncertaintics because of their relative impact on unit and total costs. Assumptions for contingencies, maintenance, and indirect costs are based on commonly used engineering estimating practices. Because each LLRW disposal facility is unique, estimates for contingencies and indirect charges may be $5-10 \%$ higher than those used for a more "conventional" construction project, i.e., cducation, transportation, or industrial facilities. The unit disposal rates for the four facility sizes are as follows: small, from $\$ 411 / \mathrm{ft}^{3}$ to $\$ 666 / \mathrm{ft}^{3}$ with a base rate of $\$ 499 / \mathrm{ft}^{3}$; medium, from $\$ 369 / \mathrm{ft}^{3}$ to $\$ 593 / \mathrm{ft}^{3}$ with a base rate of $\$ 444 / \mathrm{ft}^{3}$; large, from $\$ 305 / \mathrm{ft}^{3}$ to $\$ 471 / \mathrm{ft}^{3}$ with a base rate of $\$ 362 / \mathrm{ft}^{3}$; and extra-large, from $\$ 178 / \mathrm{ft}^{3}$ to $\$ 289 / \mathrm{ft}^{3}$ with a base rate of $\$ 215 / \mathrm{ft}^{3}$. Unit disposal rates for small, medium, and large facilities were affected most by changes in the number of operations staff or by salary rates; for an extra-large facility, they were affected most by changes in capital costs. All facilities were least affected by a variation of the preoperational cost. Five percent of the annual operations cost estimate is included as operator compensation during the operational and closure periods. Interest on bonds issued for the preoperational period are 5\% or less of the total cost for all sizes of disposal facilities. Community benefits and taxes during the operation of a disposal facility are about $10 \%$ of the total PLCC estimate. Unit disposal costs are most sensitive to the total disposal capacity.

PLCC estimates for each size of facility uses a 30-year operational life, a 10-ycar closure period, and a 300-year post-closure/institutional care period. Waste accepted at a facility will be from academia, medicine, government, industry, and utilities. The waste capacities of the disposal facilities are: small, 1,050,000 $\mathrm{ft}^{3}$; medium, 1,500,000 $\mathrm{ft}^{3}$; large, 2,400,000 $\mathrm{ft}^{3}$; extra-large, $14,000,000 \mathrm{ft}^{3}$. The total capacity for each facility allows for future waste volumes that will be generated during decontamination and decommissioning activities by major radioactive material users. Table ES-1 is a summary of the base case PLCC estimates and unit disposal rates for the four sizes of low-level radioactive waste disposal facilities. Figure ES-1 graphs the base case costs of Table ES-1 for the four sizes of facilities. 
Table ES-1. Base case cost summary for waste disposal facilities.

\begin{tabular}{lrrrr}
\hline $\begin{array}{l}\text { Work breakdown } \\
\text { structure elements }\end{array}$ & \multicolumn{1}{c}{ Small } & Medium & Large & Extra-large \\
\hline Preoperations & $\$ 81,622,000$ & $\$ 85,499,000$ & $\$ 88,623,000$ & $\$ 137,750,000$ \\
Bond interest & $\$ 30,239,000$ & $\$ 30,239,000$ & $\$ 30,504,000$ & $\$ 31,048,000$ \\
Operations & $\$ 314,518,000$ & $\$ 437,537,000$ & $\$ 598,526,000$ & $\$ 2,316,947,000$ \\
Closure & $\$ 35,993,000$ & $\$ 40,760,000$ & $\$ 52,365,000$ & $\$ 123,752,000$ \\
Post-closure & $\$ 12,757,000$ & $\$ 12,757,000$ & $\$ 19,135,000$ & $\$ 102,052,000$ \\
Community benefits & $\$ 48,316,000$ & $\$ 59,531,000$ & $\$ 80,262,000$ & $\$ 303,196,000$ \\
Total cost & $\$ 523,445,000$ & $\$ 666,323,000$ & $\$ 869,415,000$ & $\$ 3,014,745,000$ \\
Cost per cubic foot & $\$ 499$ & $\$ 444$ & $\$ 362$ & \\
\hline
\end{tabular}

a. Preoperations costs includes state costs of $\sim \$ 45 \mathrm{M}$.

Figure ES-1. Total base case costs and unit costs.

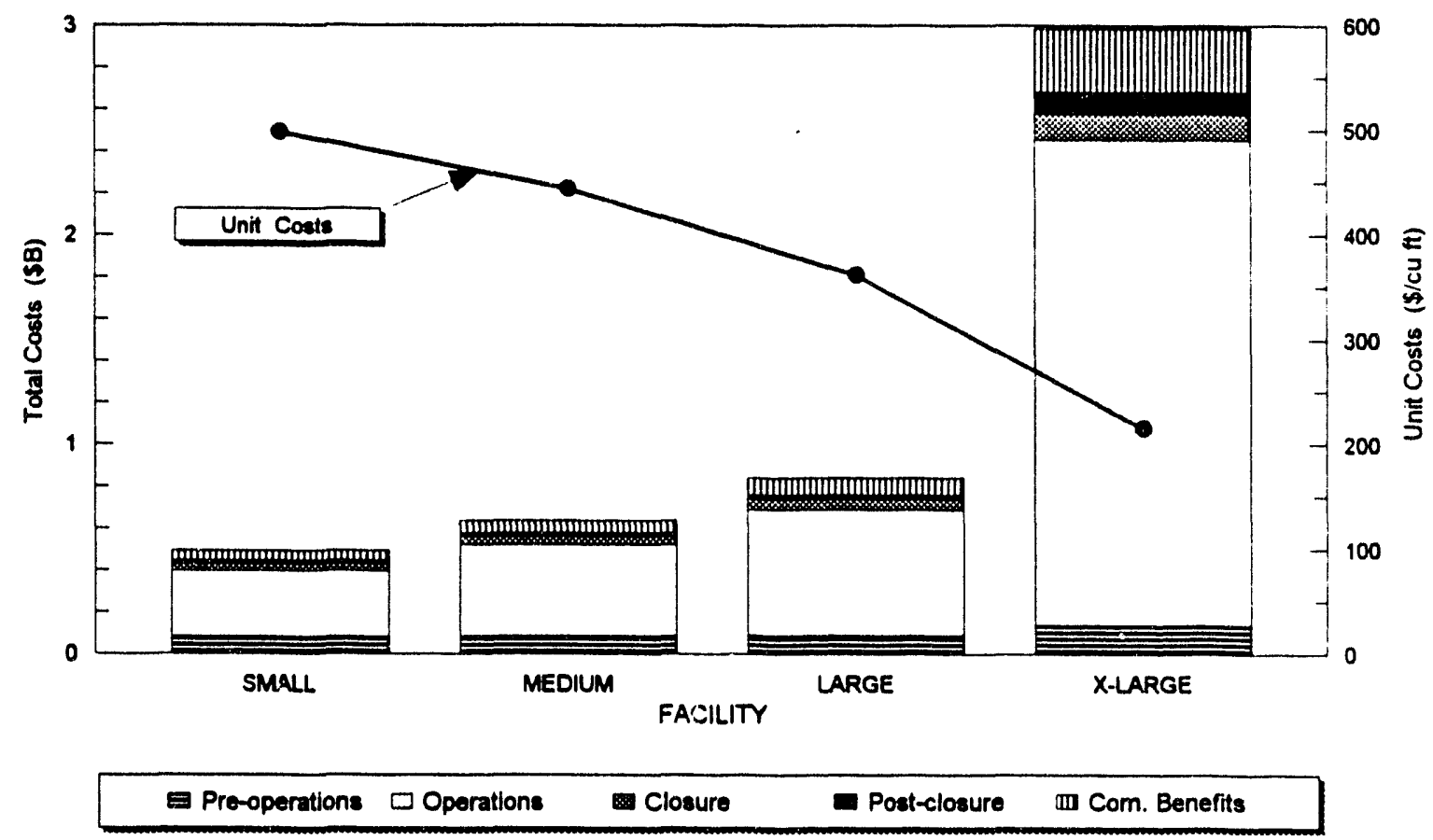




\section{CONTENTS}

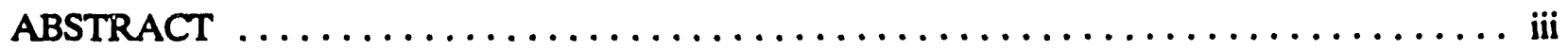

ACKNOWLEDGEMENTS $\ldots \ldots \ldots \ldots \ldots \ldots \ldots \ldots \ldots \ldots \ldots \ldots \ldots \ldots \ldots$

EXECUTIVE SUMMARY $\ldots \ldots \ldots \ldots \ldots \ldots \ldots \ldots \ldots \ldots \ldots \ldots \ldots \ldots \ldots \ldots \ldots$

1. INTRODUCTION $\ldots \ldots \ldots \ldots \ldots \ldots \ldots \ldots \ldots \ldots \ldots \ldots \ldots \ldots \ldots \ldots \ldots \ldots \ldots$

1.1 Background $\ldots \ldots \ldots \ldots \ldots \ldots \ldots \ldots \ldots \ldots \ldots \ldots \ldots \ldots \ldots \ldots \ldots \ldots$

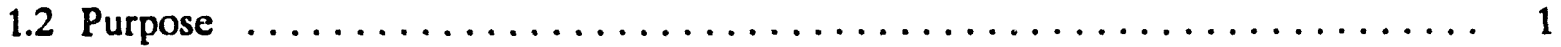

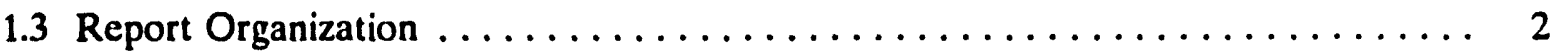

2. FACILITY DESCRIPTION $\ldots \ldots \ldots \ldots \ldots \ldots \ldots \ldots \ldots \ldots \ldots \ldots \ldots \ldots \ldots$

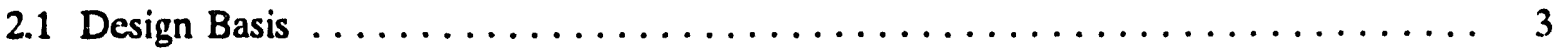

2.2 Facility Design Description $\ldots \ldots \ldots \ldots \ldots \ldots \ldots \ldots \ldots \ldots \ldots \ldots \ldots \ldots$

2.2.1 Site Development ........................ 4

2.2.2 Administration Facility $\ldots \ldots \ldots \ldots \ldots \ldots \ldots \ldots \ldots \ldots \ldots \ldots \ldots \ldots \ldots \ldots \ldots \ldots \ldots$

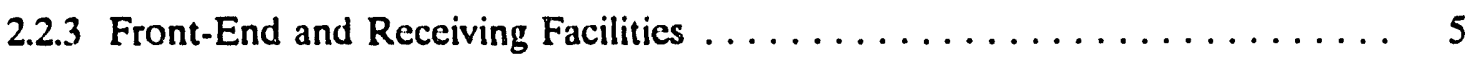

2.2.4 Waste Packaging Building $\ldots \ldots \ldots \ldots \ldots \ldots \ldots \ldots \ldots \ldots \ldots \ldots \ldots \ldots$

2.2.5 Individual Disposal Cells $\ldots \ldots \ldots \ldots \ldots \ldots \ldots \ldots \ldots \ldots \ldots \ldots$

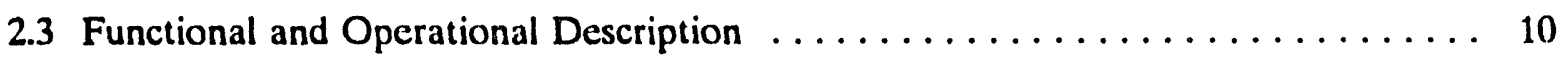

2.4 Site Functions After Cell Closure $\ldots \ldots \ldots \ldots \ldots \ldots \ldots \ldots \ldots \ldots \ldots \ldots \ldots$

3. FACILITY COST ESTIMATES $\ldots \ldots \ldots \ldots \ldots \ldots \ldots \ldots \ldots \ldots \ldots \ldots$

3.1 WBS 1.0 - Preoperation Costs $\ldots \ldots \ldots \ldots \ldots \ldots \ldots \ldots \ldots \ldots \ldots \ldots \ldots \ldots \ldots \ldots \ldots$

3.1 .1 Land Acquisition $\ldots \ldots \ldots \ldots \ldots \ldots \ldots \ldots \ldots \ldots \ldots \ldots \ldots \ldots \ldots \ldots \ldots \ldots \ldots$

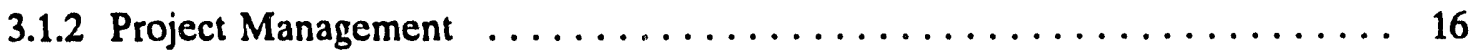

3.1.3 Site Selection and Characterization $\ldots \ldots \ldots \ldots \ldots \ldots \ldots \ldots \ldots$

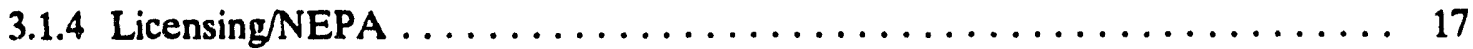

3.1 .5 Engineering Design $\ldots \ldots \ldots \ldots \ldots \ldots \ldots \ldots \ldots \ldots \ldots \ldots \ldots \ldots$

3.1 .6 Contingencies $\ldots \ldots \ldots \ldots \ldots \ldots \ldots \ldots \ldots \ldots \ldots \ldots \ldots \ldots \ldots$ 
3.1.7 Facility Construction $\ldots \ldots \ldots \ldots \ldots \ldots \ldots \ldots \ldots \ldots \ldots \ldots \ldots \ldots$

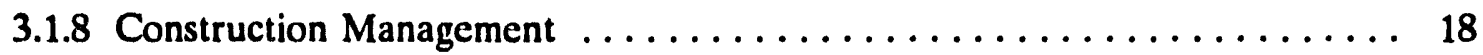

3.1.9 Contingency for Construction $\ldots \ldots \ldots \ldots \ldots \ldots \ldots \ldots \ldots \ldots \ldots, 18$

3.2 WBS 2.0 - Operation Costs $\ldots \ldots \ldots \ldots \ldots \ldots \ldots \ldots \ldots \ldots \ldots \ldots \ldots \ldots \ldots \ldots . \ldots \ldots$

3.2.1 Cell Construction ............................. 19

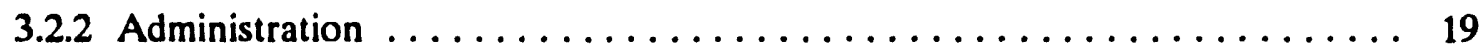

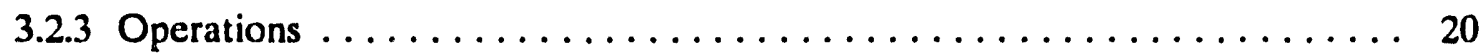

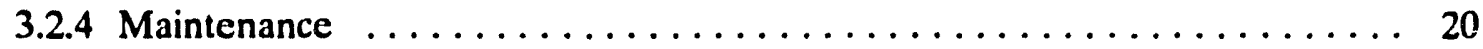

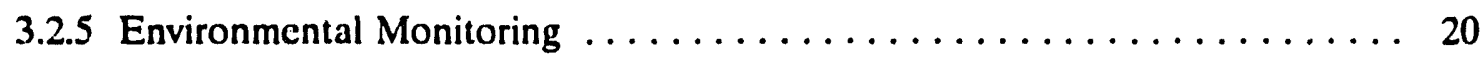

3.2 .6 Utilities/Materials $\ldots \ldots \ldots \ldots \ldots \ldots \ldots \ldots \ldots \ldots \ldots \ldots \ldots .20$

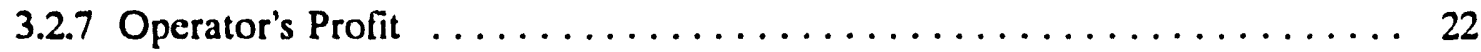

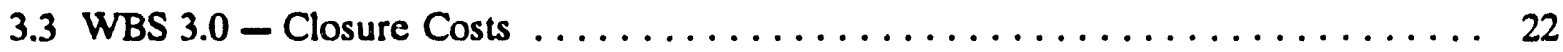

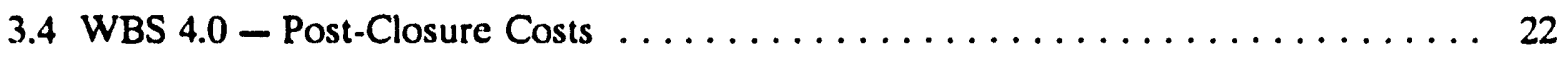

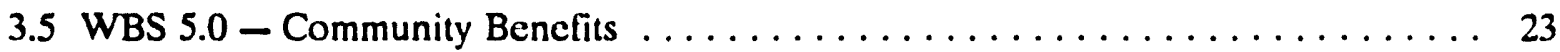

3.6 Discussion of Results $\ldots \ldots \ldots \ldots \ldots \ldots \ldots \ldots \ldots \ldots \ldots \ldots \ldots \ldots \ldots \ldots \ldots \ldots \ldots \ldots, 24$

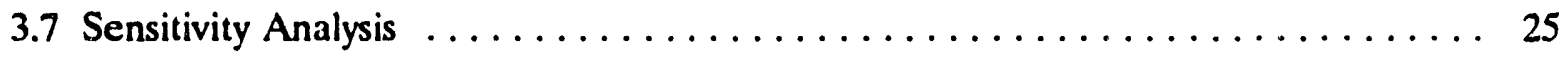

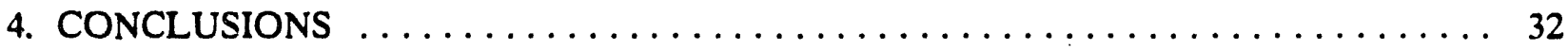

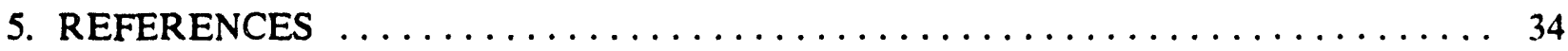

Appendix A

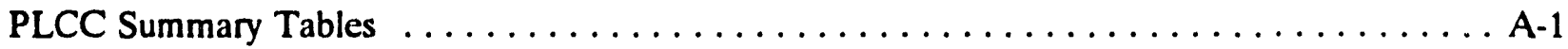

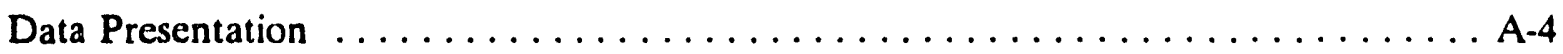

Appendix B

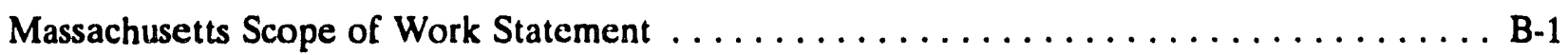


Appendix C

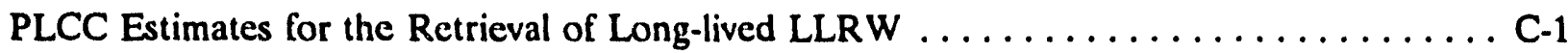

C-1 INTRODUCTION ..........................

C-2 DESCRIPTION OF RETRIEVAL FACILITY $\ldots \ldots \ldots \ldots \ldots \ldots \ldots \ldots$

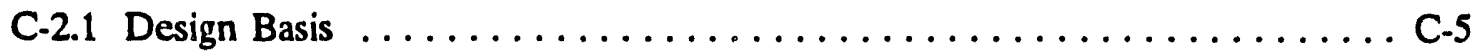

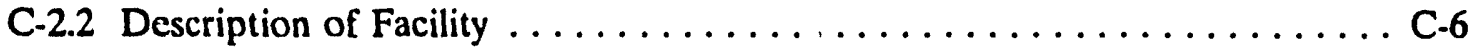

C-2.3 Description of Functions and Operations . . . . . . . . . . . C-9

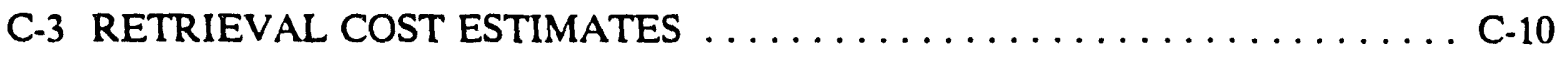

C-3.1 WBS-1 Vault Excavation and Canister Retrieval ............. C-10

C-3.2 WBS-2 Facility Construction $\ldots \ldots \ldots \ldots \ldots \ldots \ldots \ldots \ldots \ldots \ldots \ldots \ldots$

C-3.3 WBS-3 Waste Packaging Operations $\ldots \ldots \ldots \ldots \ldots \ldots \ldots \ldots$ C-13

C-3.4 WBS-4 Site Closure $\ldots \ldots \ldots \ldots \ldots \ldots \ldots \ldots \ldots \ldots \ldots \ldots$ C-14

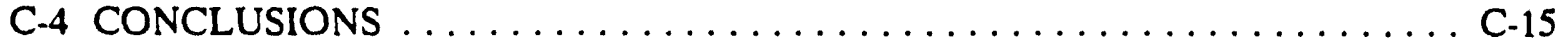

FIGURES

ES-1. Total base case costs and unit costs $\ldots \ldots \ldots \ldots \ldots \ldots \ldots \ldots \ldots \ldots \ldots$

1. Detailed disposal facility layout $\ldots \ldots \ldots \ldots \ldots \ldots \ldots \ldots \ldots \ldots \ldots \ldots \ldots$

2. Disposal facility layout $\ldots \ldots \ldots \ldots \ldots \ldots \ldots \ldots \ldots \ldots \ldots \ldots \ldots \ldots \ldots \ldots \ldots \ldots$

3. Oblique view of an earth-mounded disposal vault $\ldots \ldots \ldots \ldots \ldots \ldots \ldots \ldots$

4. Process functional diagram of disposal facility activities $\ldots \ldots \ldots \ldots \ldots \ldots \ldots \ldots$

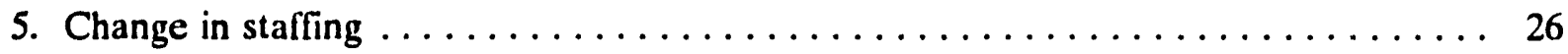

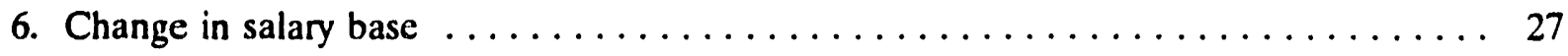

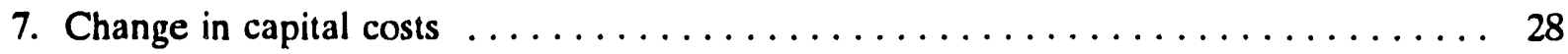

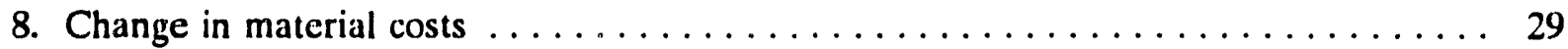

9. Change in state costs $\ldots \ldots \ldots \ldots \ldots \ldots \ldots \ldots \ldots \ldots \ldots \ldots \ldots \ldots \ldots \ldots$

C-1. Oblique view of conceptual excavation and retrieval area $\ldots \ldots \ldots \ldots \ldots \ldots \ldots$

C-2. Plan view of canister receiving and packaging facility $\ldots \ldots \ldots \ldots \ldots \ldots \ldots$

C-3. Process functional diagram for vault excavation, canister retrieval activities, and site

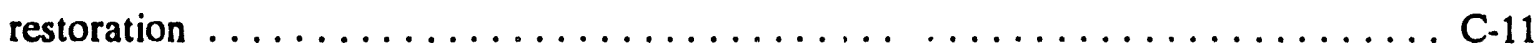

C-4. Process functional diagram for canister receiving and packaging facilities . . . . . C-12

C-5. PLCC retrieval cost comparisons $\ldots \ldots \ldots \ldots \ldots \ldots \ldots \ldots \ldots \ldots \ldots$ C 17 


\section{TABLES}

ES-1. Base case cost summary for waste disposal facilities $\ldots \ldots \ldots \ldots \ldots \ldots \ldots \ldots$

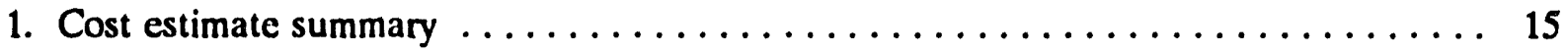

2. Capital cost factors for different front-end and receiving facilities $\ldots \ldots \ldots \ldots$

3. Annual salary for full-time employecs $\ldots \ldots \ldots \ldots \ldots \ldots \ldots \ldots \ldots \ldots \ldots \ldots$

4. Massachusetts community benelits and compensation $\ldots \ldots \ldots \ldots \ldots$

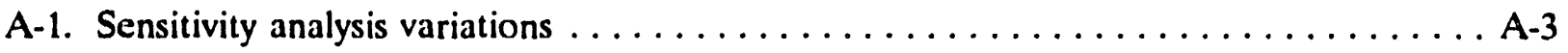

C-1. PLCC Summary Costs for Retrieval $\ldots \ldots \ldots \ldots \ldots \ldots \ldots \ldots \ldots \ldots \ldots$

C-2. Summary of PLCC estimates for long-lived LLRW retrieval $\ldots \ldots \ldots \ldots \ldots \ldots$ 


\section{Estimating Costs of Low-Level Radioactive Waste Disposal Alternatives for the Commonwealth of Massachusetts}

\section{INTRODUCTION}

\subsection{Background}

The Massachusctts Low-Level Radioactive Waste Management Board (the Board) is charged by State and Federal law to provide for the short-term management and long-term disposal of low-level radioactive waste (LLRW). LLRW is generated in the Commonwealth by various academic, health care, commercial, government, and utility users of radioactive materials. In connection with the above charge, the Board must decide whether to initiate siting activities for an LLRW disposal facility.

Options for managing LLRW out of state may be available in the future. These options may include contracts with individual states, or with a group of states (known as a "compact") bound together for the purpose of regional LLRW disposal. Currently, all states and compact regions, except for the Southeast Compact Region, that have or that are developing disposal capabilities have either adopted explicit statutory prohibitions or have communicated an unwillingness to accept LLRW from outside their state or compact. Access to the Southeast Compact regional disposal facility is due to close on July 1, 1994.

Accordingly, the Board has asked the National Low-Level Waste Management Program of the U.S. Department of Energy to develop a report on the costs of various in-state disposal options.

\subsection{Purpose}

The purpose of this report is to develop the planning life-cycle cost (PLCC) estimates for four sizes of in-state LLRW disposal facilities (small, medium, large, and extra-large). The PLCC estimates for all capital and operating costs expected during the site selection, characterization, licensing, construction, operation, closure, and post-closure activities are based on a preliminary feasibility design of the Illinois Low-Level Radioactive Waste Disposal Facility (ILLRWDF).

It is intended that this report be used as a broad decision making tool for evaluating one of the several complex factors that must be examined when deciding between various LLRW management options - relative costs. Because the underlying assumptions of these analyses will change as the Board decides how it will manage Massachusett's waste and the specific characteristics the disposal facility will have, the results of this study are not absolute and should only be used to compare the relative costs of the options presented.

A separate PLCC estimate for retrieval of the long-lived waste is also being developed, but will be inserted later into the this document. Since Massachusetts law M.G.L. c. $111 \mathrm{H}$ s.46 states ..."that the institutional control period shall not be less than the minimum time required for any 
LLRW present at the site to decay to the maximum concentrations above natural background levels permitted to be released into the air or water in unrestricted areas under federal and state law"..., it is assumed that all long-lived LLRW will need to be retrieved at the end of the institutional control period. The PLCC contained in this report and for the retrieval insert are based on the assumption that $50 \%$ of the received wastes are short-lived and $50 \%$ are long-lived. A list of the assumptions for waste retrieval is in Appendix C. The PLCC retrieval estimate will include the construction of new waste handling facilities, excavation of disposal vaults, removal of waste containers, assaying and verification of the retrieved waste containers, onsite repacking of $5 \%$ of the retrieved waste canisters, preparation for shipment of the retrieved waste, and restoring the disturbed site. Assumptions regarding transportation and additional disposal costs will not be evaluated since these factors cannot be defined at this time.

\subsection{Report Organization}

This report is divided into five sections. Section 1 presents the background and purpose. Section 2 contains descriptions of the facilities that comprise the waste disposal complex. Section 3 details the PLCC estimates of each component of the facilities. Section 4 contains a discussion of the sensitivity analysis and the overall conclusions. Section 5 lists the references. The detailed cost estimate tables and the scope of work are presented in Appendices A and B, respectively. Appendix $C$ is the discussion and the results of the PLCC estimate for retricval of the long-lived LLRW. 


\section{FACILITY DESCRIPTION}

\subsection{Design Basis}

The disposal facility cost estimates are based on the following assumptions:

- Facilities are sized for 35,000 (small); 50,000 (medium); 80,000 (large); and 466,000 $\mathrm{ft}^{3}$ (extra-large) of waste per year. Waste will be $50 \%$ short-lived and $50 \%$ long-lived.

- Minimum land allowances for small, medium, large, and extra-large facilities are 100 acres, 100 acres, 130 acres, and 420 acres, respectively.

- The preoperational phase includes construction of support buildings and disposal cells ( 5 cells for small, medium, and large; 15 cells for extra-large).

- Operational activitics include construction of 0.9 cells/year for a small facility, 1.4 cells/year for a medium facility, 2.4 cells/year for a large facility, and 14.8 cells/year for an extra-large facility.

- The facilities will operate 16 hours/day, 5 days/week, 240 days/year.

- Solidified waste is reccived in approved shipping containers, placed into concrete canisters and grouted.

- The concrete canisters are 5-ft square and 7-ft high, and the walls are 0.5 -ft thick.

- The facility shall operate and accept waste for 30 years.

- The closure period is 10 years.

- The institutional control period is 300 years.

- The facility shall meet the requirements of 10 CFR 61 .

- The facility will have features for waste retrieval during the institutional control period.

- Long- and short-lived waste will be segregated in separate cells. The same cell design will be used for both waste types. (Massachusetts chose to separate waste as long- or short-lived waste rather than as Class A, Class B, or Class C waste.)

- Each cell is a structurally separate unit with outside dimensions of 93 by 62 by $26 \mathrm{ft}$. The cells will have 2.5 -ft-thick concrete walls and a 2.5 -ft-thick concrete floor and roof.

- Cells will be backfilled with dry granular material after placement of the waste canisters.

- An engineered, earthen cap will be placed over the vaults. 


\subsection{Facility Design Description}

The conceptual LLRW disposal facility is comprised of two major components: support facilities and a disposal area. The layouts for administration, front-end and receiving, and disposal areas are provided in Figures 1 and 2.

Support facilities for the disposal cells include administration, front-end and receiving areas, and a waste packaging building. These areas will be used for site management, maintenance, and to prepare waste for disposal. Most of the buildings will be demolished during the closure period, after the facility stops accepting waste.

Earth-covered, aboveground concrete vaults are used as the basis for estimating the cost of LLRW disposal. The design concept used for this PLCC analysis is similar to that adopted by the Central Midwest Interstate Low-Level Radioactive Waste Compact for the ILLRWDF. Disposal vaults are comprised of parallel rows of cast-in-place reinforced concrete walled rooms (cells) 93 by 62 feet wide and 26 feet high. LLRW disposal in aboveground engineered vaults will provide at least three engineered barriers to prevent waste from escaping. These barriers are the shipping containers, concrete canisters, and the vault system.

The waste is received onsite, then inspected and assayed to ensure it meets the facility's waste acceptance criteria. Waste is then transferred to the waste packaging building where it is placed into concrete canisters and filled with a cement/sand grout mixture. After the grout has cured, the waste canisters are assayed, labeled, and transported to a disposal cell. Once a disposal cell is filled with canisters, any remaining void is filled with sand. A roof of concrete panels is placed to seal the cell. An engineered multi-layered earth materials sap is mounded over the disposal vaults for additional protection. The disposal cells are monitored for potential waste migration and are designed to facilitate waste canister retricval. The system of concrete roof panels will allow for retrieval of waste at anytime during the life of the facility and for retrieval of long-lived wastes at the end of the institutional control period.

The list of assumptions and the description of the aboveground disposal system used in these PLCC estimates are based on the disposal concepts developed for the ILLRWDF. The methods and assumptions described here were used to generate detailed cost estimates. These estimates are to be used for planning-level analyses and to compare the relative costs of the options described in this study. The use of this model and the results of these analyses do not necessarily represent a preferred disposal system that may be developed by the state of Massachusetts, either now or in the future.

\subsubsection{Site Development}

Site development is comprised of the fundamental site preparation and infrastructure construction necessary for disposal operations. This includes site grubbing and grading, installation of a stormwater retention and treatment basin, development of a borrow/materials storage site, power services, sewage and potable water service, emergency services, fire/water systems, communications, fencing, and site access. 


\subsubsection{Administration Facility}

The administration building includes management offices, a reception area, multi-use rooms, a computer center, a records vault, restrooms, lunchrooms, a storage area, and a mechanical and electrical equipment area. A fire alarm system is included in the cost estimate for the administration building.

\subsubsection{Front-End and Receiving Facilities}

The front-end and receiving facilities include the site access and guard staition; a maintenance, warehouse, truck inspection and washout, and laboratory building; utility, and mechanical and machinery buildings; and an clectrical distribution and control center.

The site access building is a control point for all personnel and vehicles entering or leaving the disposal area. The building is comprised of a guard station, frisk and decontamination areas, a lunchroom, a driver's lounge, a site monitoring room, and a communications support area. The maintenance/warehouse and truck inspection building houses the environmental health physics laboratory and is equipped with a dedicated air system and isolated by reinforced concrete masonry walls from the other activities in the area.

The maintenance and warehouse building contains a bay for vehicle maintenance and storage of site equipment and supplies. It will also serve as a maintenance area for smaller onsite equipment and for constructing temporary shiclding supports, special test fixtures, and other siterelated items. Cost estimates include all appropriate supplies and tools.

Incoming waste shipments are examined in the covered truck inspection and washout building. Inspection may include visual inspection, manifest checks, and radiological surveys. The building contains a second enclosed truck bay for washing vehicles before departure. This second bay may be used to de-ice incoming trucks during winter months. Water generated from washing and de-icing operations is collected for analysis. Contaminated water is retained in a separate holding tank for treatment by grout solidification and disposal. Clean water is recycled.

The utility, mechanical, and machinery buildings are located near the perimeter of the restricted area. These buildings house a diesel-powered emergency generator, diesel-fuel day tanks, and an emergency firewater pump system. All accessories for the generator are included. 


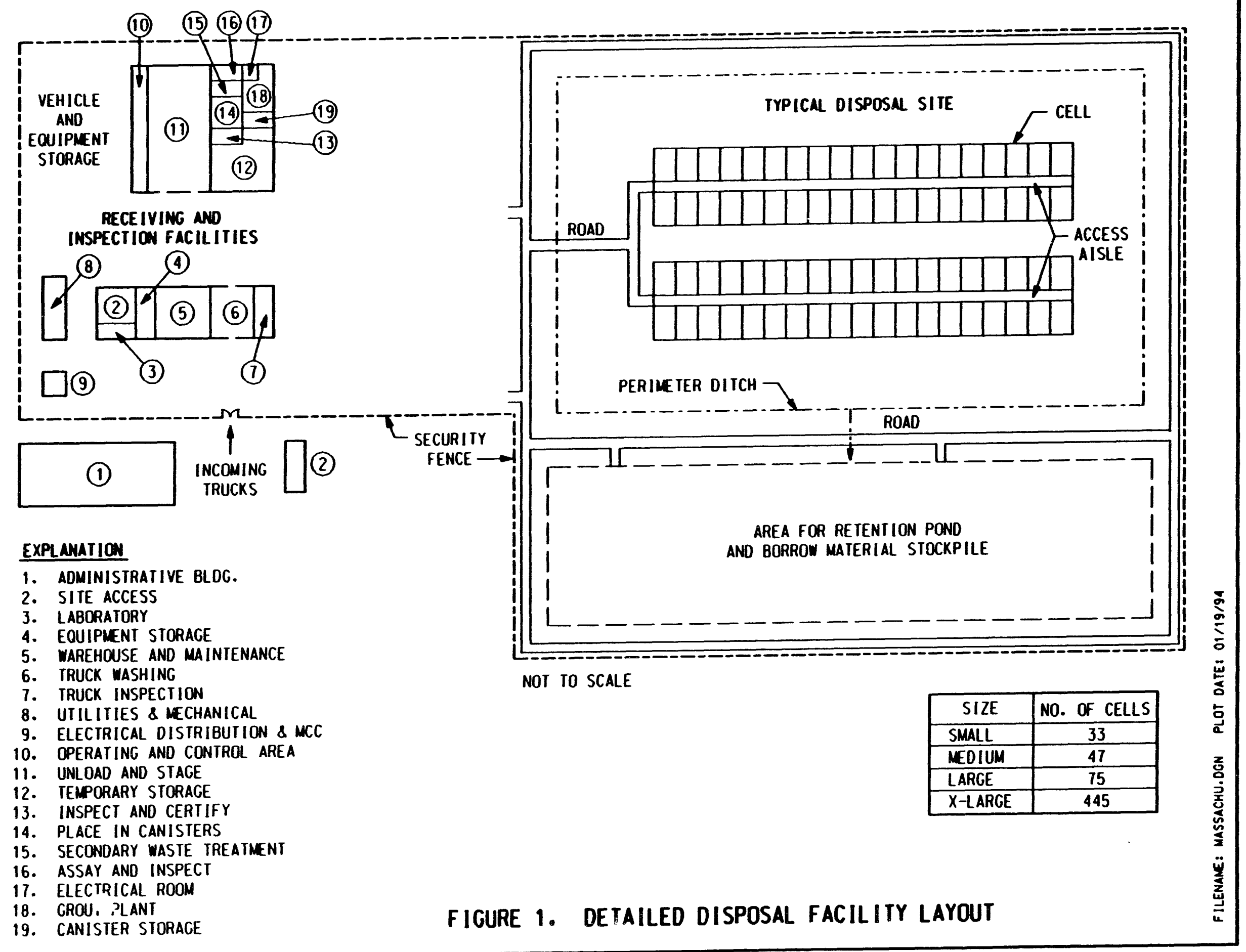




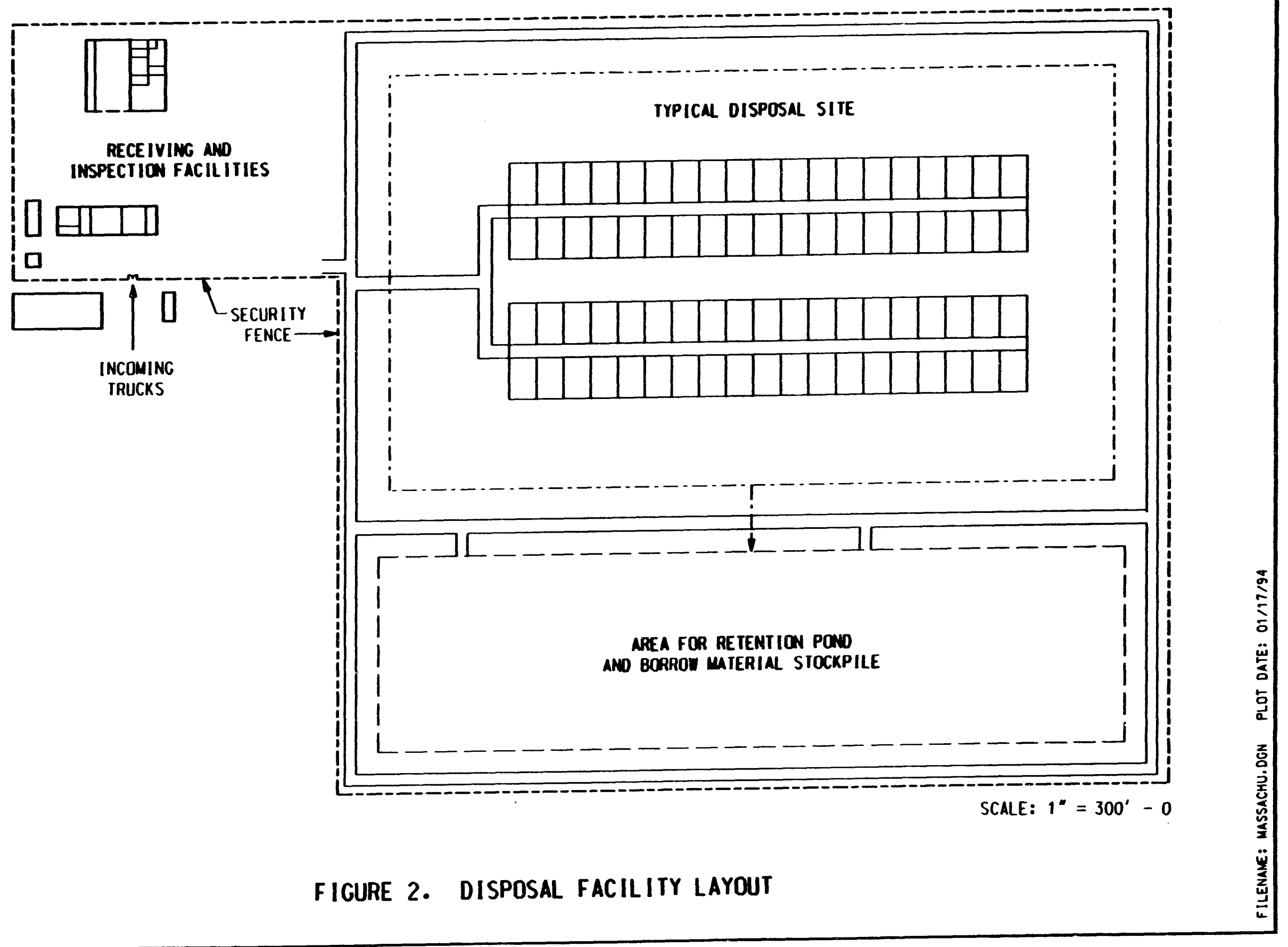




\subsubsection{Waste Packaging Building}

The waste packaging building is a separate cost item from the front-end and receiving facilities. It includes all equipment and tools for the unloading and staging areas, inspection operations, secondary waste treatment, grout plant, canister storage, and waste packaging area.

Unloading, staging, and waste packaging takes place in a covered truck bay area where the waste shipping containers are unloaded by an overhead bridge crane, and the waste is inspected and placed into concrete canisters. The truck bay has a sloped concrete floor for positive drainage. The walls are epoxy-coated for decontamination. After the waste is placed into canisters, all canisters are tilled and sealed with grout. Cement for the grout is stored in a silo equipped with a pneumatic delivery pump. Sand is stored in a silo with appropriate discharge equipment. Grout is mixed and pumped to the waste packaging arca.

\subsubsection{Individual Disposal Cells}

Each disposal cell is constructed of cast-in-place concrete forming 2.5 -ft-thick walls and floors. The cells are grouped together in two parallel rows to form a disposal vault. An access aisle, 30-ft wide, separates the two parallel rows of cells. The waste canisters are transported from the waste packaging building and placed into an open disposal cell. After filling a cell to capacity, a 2.5-ft-thick reinforced-concrete wall seals the cell from the aisle. Each cell is backfilled with dry sand. The cell roof consists of tight fitting pre-cast concrete panels secured on the top of the cell in a manner to allow future retrieval of waste. Primary monitoring and leak detection systems will be installed during construction. The monitoring network may include fixed ports or remote monitoring points that can be accessed from locations outside the disposal cell. An oblique view of a disposal cell is shown in Figure 3. 


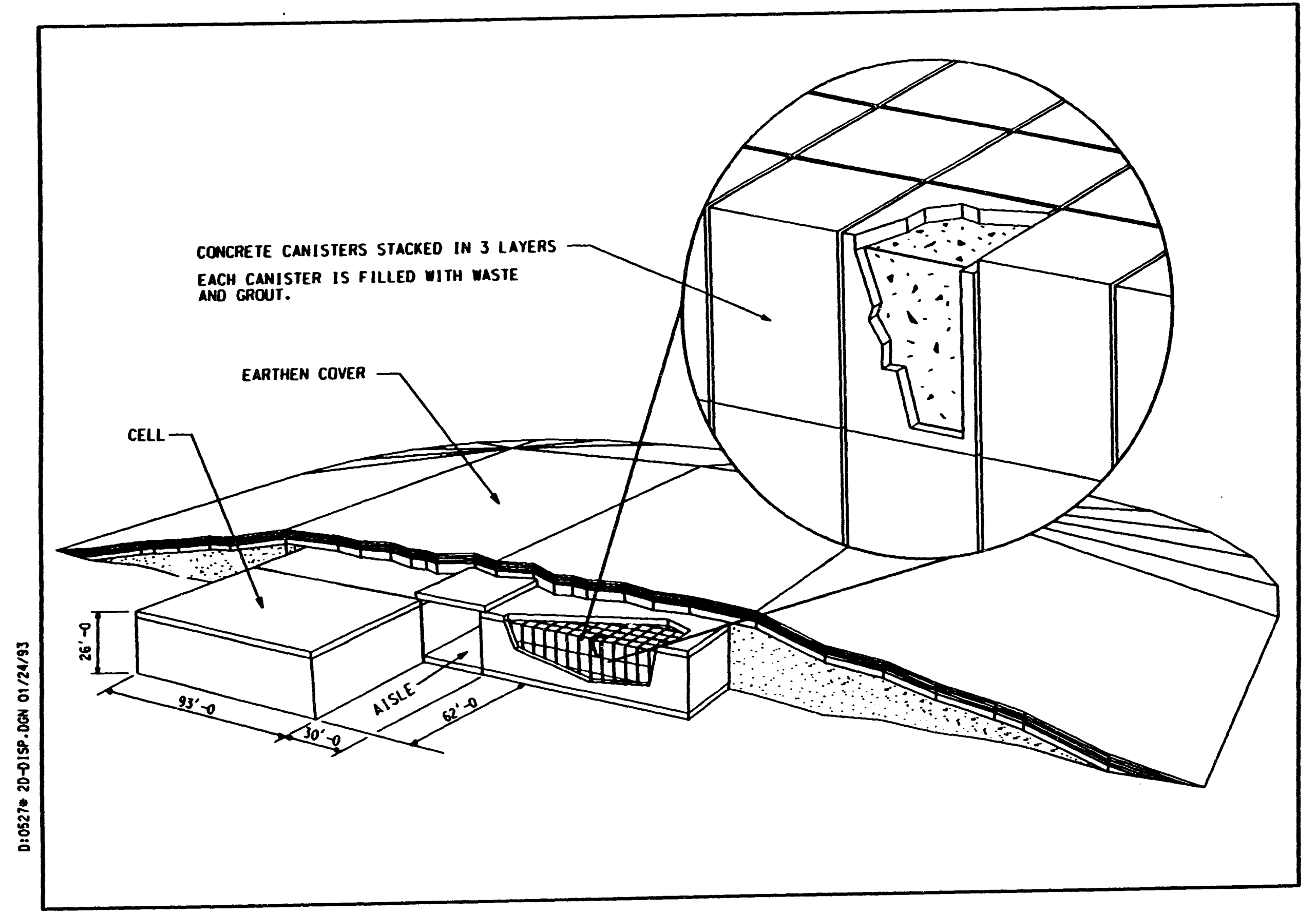

Figure 3. Oblique view of an earth-mounded disposal vault. 


\subsection{Functional and Operational Description}

The following functional and operational descriptions are based on the disposal concepts proposed to be used by the Central Midwest Compact from which the PLCC estimates were generated. The actual disposal method selected by the Commonwealth may vary from this system. The disposal facilities are separated into operational units as shown in the process functional diagram (Figure 4) which also shows the annual waste processing capacities and materials demands. Waste will be transported to the facility in approved shipping containers, such as 55gallon drums, large cylinders, and fiberglass and metal boxes, and received at the site access station, where it is assayed and inspected. A set of criteria will be developed for the classification and acceptance of LLRW and may include considerations such as; the radiological toxicity and radioactive half-lives; radionuclides and concentrations; specific radioactivity; chemical and biological toxicity and form; chemical reactivity; and other characteristics considered necessary to determine which classes of LLRW may be stored for decay, processed for waste disposal, or require special management. The waste will be transported to the waste packaging building after it is accepted. Delivery vehicles will be readied for departure at the truck inspection and washout building.

At the waste packaging building, all accepted waste packages are placed into concrete canisters and the waste is grouted in-place in the concrete canisters. The water, sand, and cement annual use rates shown in Figure 4 assume this scenario. Secondary waste generated during operations includes decontamination waters, storm water run-off, used personal protective equipment, and damaged shipping containers. Secondary waste generation is assumed to be $2 \%$ of the annual volume. Filled waste canisters are delivered to an open disposal cell. Canister placement begins at the back of the cell and progresses toward the aisle. The canisters are placed in rows 3 high, and 11 by 17 canisters wide. A 3-foot wide void between the canisters and cell wall will be filled with sand before cell closure. Each cell is sealed with removable concrete roof panels to protect the waste until the engineered cap is placed.

\subsection{Site Functions After Cell Closure}

Once the cells are filled with canisters, backfilled with sand, and sealed by the concrete roof, the entire vault system is covered by an engincered cap composed of layers of sand, clay, cobbles, and topsoil. The site is then decommissioned over a 10-year closure period. Decommissioning includes the removal of services and structures not essential for long-term management, regrading the site, planting vegetation, and other preparations for transferring the site to State control for the 300-year institutional care period. The initial activities of the institutional care period will include frequent monitoring of the vaults and waste, the land surrounding the vaults; performing site groundwater and soil cleanup; conducting a performance assessment based on the inventory of disposed radionuclides; reestablishing site vegetation; restricting public access and maintaining site security; and verify the performance of the disposal system. Once these activities are complete, the remainder of the institutional care period will be used mainly to maintain site security, continue site monitoring, and perform 'mited site remediation and maintenance. The total time commitment for the operation of the LLRW disposal facility is 340 years. 


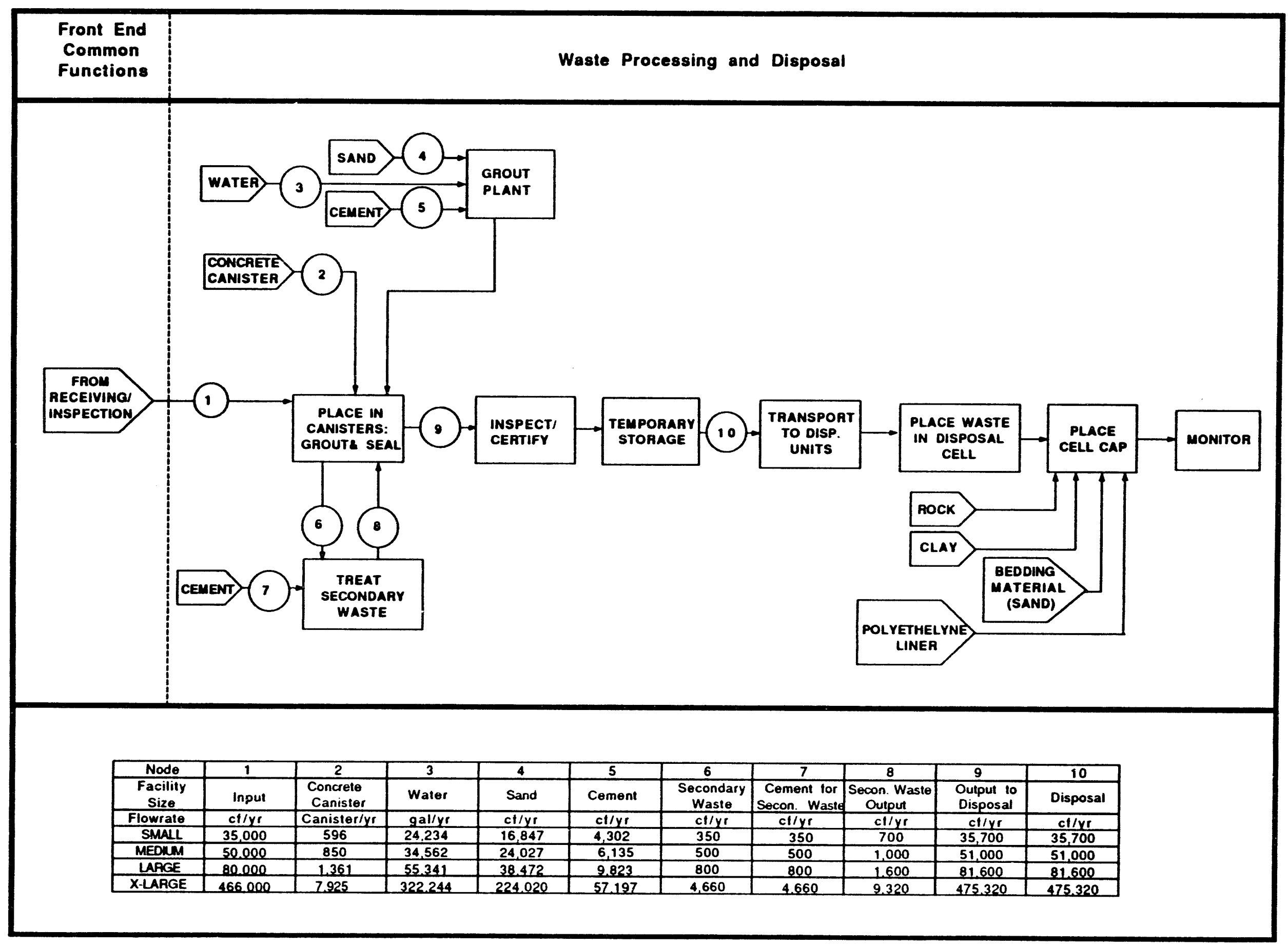




\section{FACILITY COST ESTIMATES}

This section discusses the estimating procedure and the cost estimate summary of the work breakdown structure (WBS) shown in Table 1. Preoperational siting cost estimates provided by the Board vary slightly for different sizes of disposal facilities. The total cost for the 12 preoperational activities is about $\$ 45$ million and is detailed in Table 1, items WBS-1.1 through WBS-1.6. This is based on similar program costs or low-level waste siting activities experienced by other states or compacts. It also includes State mandated community involvement and technical support program expenses. The costs reflect the belief that the program can be accomplished in Massachusetts at a lesser cost by using experience gained from other programs. Conversely, experience by opponents in challenging LLRW disposal siting programs could increase these costs through delays or litigation.

Construction, operation, and closure cost estimates are derived from the preliminary feasibility design study of the ILLRWDF. All costs in this report are expressed in first quarter 1994 dollars. PLCC estimates are based on Morrison Knudsen Corporation's construction cost estimating program. Estimating capabilities of the program include civil engineering, concrete, earthwork, structural steel, facilities (civil/architectural/structural), electrical, mechanical, and piping and instrumentation. Standard task performance times, labor, and material unit costs are embedded in the program. For the four sizes of LLRW disposal facilities considered, the unit construction rates are applied to design parameters such as the square footage of concrete structures (disposal cells), acres of earthwork, lincal feet of utilities, and the square footage for lighting demands and emergency systems (fire or back-up power).

To yield capital cost estimates from the program, factors for the four disposal facilities were determined in the following manner. First, a scaling factor was determined for scaling each cost factor for the required facility sizes. For example, the disposal cell construction costs for the small disposal facility with 33 disposal cells has an initial factor of $0.17(33+192 ; 192$ cells for the ILLRWDF). Second, by using the "6/10 rule" for all new building areas, the scaling factors are adjusted appropriately up or down depending on the complexity of construction or necessary hardware. (The $6 / 10$ rule is a common tool for estimating the cost of machinery, equipment, buildings, or other capital improvements.) Third, these factors were escalated by $3.5 \%$ per year, or $10.5 \%$, from the ILLRWDF 1990 dollar estimates to first quarter 1994 dollars. And fourth, the escalated scaling factor was adjusted by a dimensionless number for construction cost differences between Massachusetts and Illinois using the Means cost index ${ }^{1}$ where Illinois $=97.6$ and Massachusetts $=107.44$.

The PLCC estimates are presented in current dollars without a present value analysis. Present value is best used when a disposal facility is currently in operation, or would be within a few years, and has a set of precise, well-defined assumptions. Because this is not the case for this cost study, present value was not used. This allows the estimates to better account for the tentative nature of the underlying assumptions and relative nature of the cost scaling process. 
Table 1. Cost estimate summary.

\begin{tabular}{|c|c|c|c|c|c|}
\hline \multicolumn{2}{|r|}{ PLCC Eatimates for 4 Sizes of Dispoes Facilitioe } & (x smgoll & (x) Modium & $(x+1008)$ & 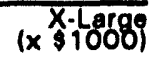 \\
\hline \multirow{4}{*}{1.0} & \multirow{4}{*}{ 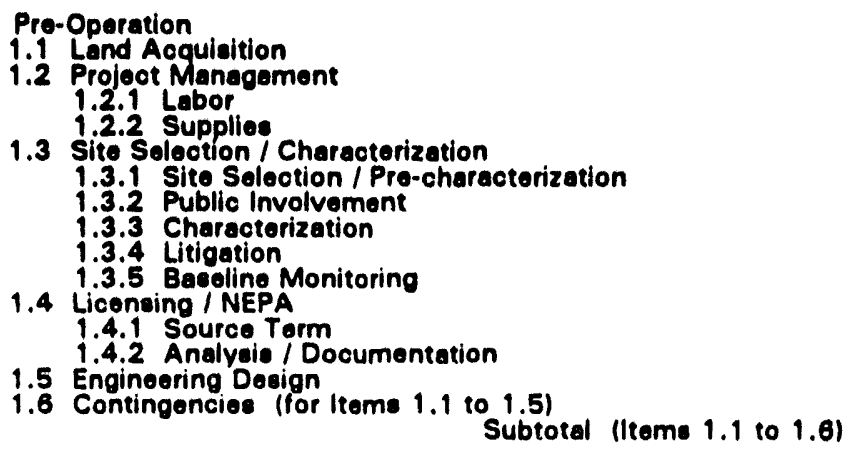 } & 3,000 & 3,000 & 3,393 & 4,200 \\
\hline & & $\begin{array}{r}4,000 \\
187\end{array}$ & $\begin{array}{r}4,000 \\
187\end{array}$ & $\begin{array}{r}4,000 \\
187\end{array}$ & $\begin{array}{r}4,000 \\
187\end{array}$ \\
\hline & & $\begin{array}{r}2,300 \\
5,000 \\
11,000 \\
1,000 \\
1,508\end{array}$ & $\begin{array}{r}2,300 \\
5,000 \\
11,000 \\
1,000 \\
1,508\end{array}$ & $\begin{array}{r}2,300 \\
5,000 \\
11,000 \\
1,000 \\
1,508\end{array}$ & $\begin{array}{r}2,300 \\
5,000 \\
11,000 \\
1,000 \\
1,508\end{array}$ \\
\hline & & $\begin{array}{r}250 \\
8,377 \\
4,500 \\
3,771 \\
44,893 \\
\end{array}$ & $\begin{array}{r}250 \\
8,377 \\
4,500 \\
3,771 \\
44,893 \\
\end{array}$ & $\begin{array}{r}250 \\
8,377 \\
4,500 \\
3,771 \\
45,286 \\
\end{array}$ & $\begin{array}{r}250 \\
8,377 \\
4,500 \\
3,771 \\
46,093 \\
\end{array}$ \\
\hline \multicolumn{2}{|r|}{ 1.6.1 Intereet and Principal on Stute Bonde (due 2018) } & 75.132 & 76.132 & 76.790 & 77.141 \\
\hline \multirow{2}{*}{\multicolumn{2}{|c|}{ 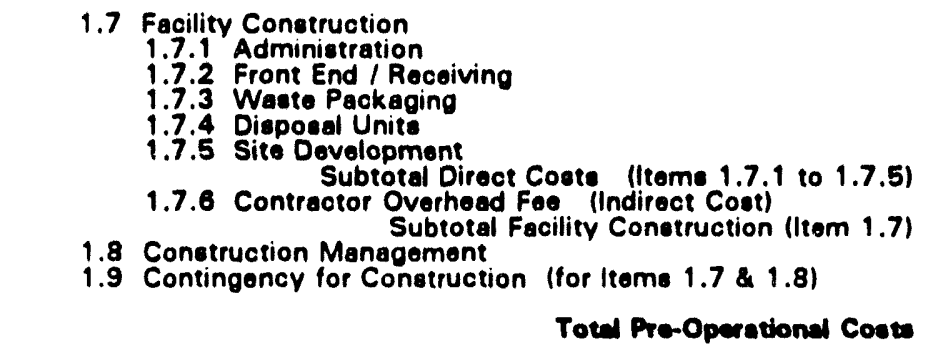 }} & $\begin{array}{r}1,498 \\
1,921 \\
2,348 \\
7,931 \\
6,707 \\
20,405 \\
4,081 \\
24,486 \\
4,897 \\
7,346\end{array}$ & $\begin{array}{r}1,732 \\
2,377 \\
3,062 \\
7,931 \\
7,457 \\
22,559 \\
4,512 \\
27,071 \\
5,414 \\
8,121\end{array}$ & $\begin{array}{r}2,221 \\
2,493 \\
3,062 \\
7,931 \\
8,368 \\
24,076 \\
4,815 \\
28,891 \\
5,778 \\
8,667\end{array}$ & $\begin{array}{r}4,487 \\
5,544 \\
6,555 \\
19,640 \\
14,696 \\
50,921 \\
10,184 \\
61,105 \\
12,221 \\
18,331\end{array}$ \\
\hline & & 81.622 & 86,499 & 88.623 & 137.750 \\
\hline \multirow[t]{2}{*}{2.0} & \multirow[t]{2}{*}{ 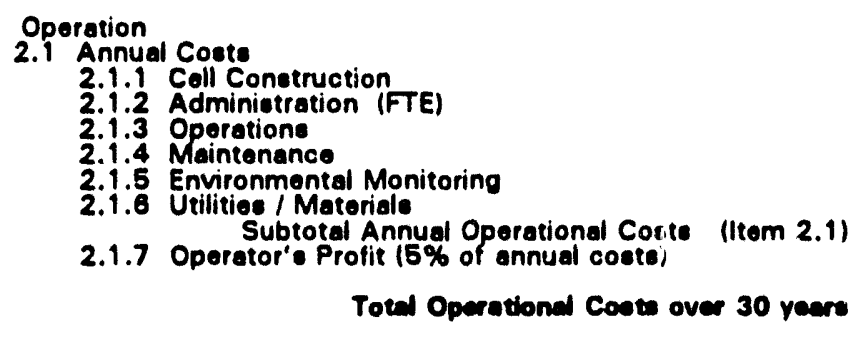 } & $\begin{array}{r}1,481 \\
4,151 \\
1,840 \\
104 \\
275 \\
2,135 \\
9.985 \\
499\end{array}$ & $\begin{array}{r}2,221 \\
5,208 \\
2,807 \\
155 \\
275 \\
3,224 \\
13,890 \\
695\end{array}$ & $\begin{array}{r}3,701 \\
5,994 \\
4,159 \\
259 \\
413 \\
4,475 \\
19,001 \\
950\end{array}$ & $\begin{array}{r}18,767 \\
13,340 \\
19,889 \\
1,314 \\
2,200 \\
18,044 \\
73,554 \\
3,578\end{array}$ \\
\hline & & 314,518 & 437.637 & $\mathbf{5 9 8 . 5 2 8}$ & $2,316,947$ \\
\hline \multirow[t]{2}{*}{3.0} & \multirow{2}{*}{ 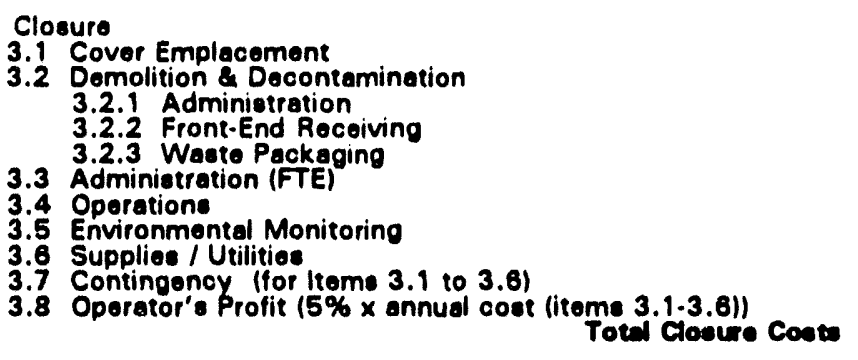 } & 671 & 955 & 1,524 & 7,926 \\
\hline & & $\begin{array}{r}449 \\
961 \\
1,174 \\
18,164 \\
2920 \\
2,760 \\
2,609 \\
68,922 \\
1,384 \\
38,993\end{array}$ & $\begin{array}{r}520 \\
1,189 \\
1,531 \\
19,054 \\
1,403 \\
2,750 \\
3,952 \\
7,838 \\
7,568 \\
40,760\end{array}$ & $\begin{array}{r}666 \\
1,247 \\
1,531 \\
24,101 \\
2,079 \\
4.125 \\
5,008 \\
10,070 \\
\mathbf{2}, 014 \\
\mathbf{6 2 , 3 6 8}\end{array}$ & $\begin{array}{r}1,346 \\
2,772 \\
3,277 \\
36,924 \\
9,945 \\
22,000 \\
11,004 \\
23,798 \\
4,760 \\
123,762\end{array}$ \\
\hline \multirow[t]{2}{*}{4.0} & $\begin{array}{l}\text { Post-Closure } \\
4.1 \text { Environmental Monitoring } \\
4.2 \text { Sito Remodiation } \\
4.3 \text { Socurity } \\
4.4 \text { Maintenance }\end{array}$ & $\begin{array}{r}5,400 \\
5,440 \\
1,082 \\
\underline{836} \\
\end{array}$ & $\begin{array}{r}5,400 \\
5,440 \\
1,082 \\
135 \\
\end{array}$ & $\begin{array}{l}8,100 \\
8,160 \\
1,623 \\
1,252 \\
\end{array}$ & $\begin{array}{r}43,200 \\
43,520 \\
8,656 \\
6,676 \\
\end{array}$ \\
\hline & Total Post-Closure Coote & 12.757 & 12.767 & 19,135 & 102,062 \\
\hline \multirow[t]{3}{*}{5.0} & \multirow{3}{*}{ 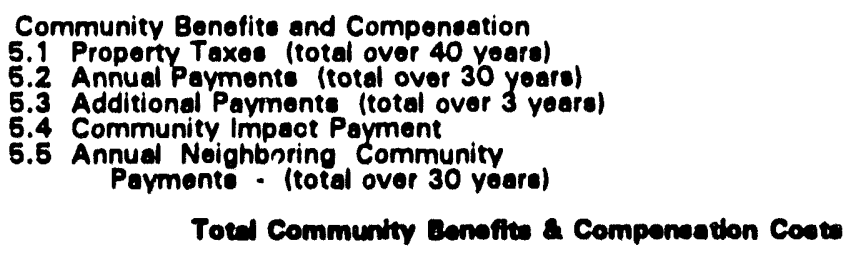 } & $\begin{array}{r}35,866 \\
7,200 \\
460 \\
3,000\end{array}$ & $\begin{array}{r}47,081 \\
7,200 \\
450 \\
3,000\end{array}$ & $\begin{array}{r}67,812 \\
7,200 \\
450 \\
3,000\end{array}$ & $\begin{array}{r}284,746 \\
12,000 \\
450 \\
3,000\end{array}$ \\
\hline & & 1,800 & 1,800 & 1,800 & 3,000 \\
\hline & & 48,310 & 59.531 & 80,282 & 303,198 \\
\hline \multicolumn{2}{|r|}{ 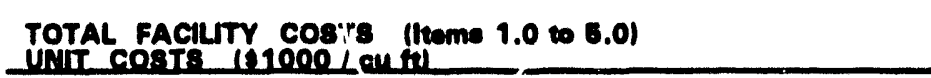 } & $\begin{array}{r}823,448 \\
0.100\end{array}$ & $\begin{array}{r}686,323 \\
0,44 \\
\end{array}$ & $\begin{array}{r}869,418 \\
0.31 . \\
\end{array}$ & $\begin{array}{r}3,014,746 \\
0.22 \\
\end{array}$ \\
\hline
\end{tabular}




\subsection{WBS 1.0 - Preoperation Costs}

The preoperational costs are listed by item in the cost summary, Table 1. These include direct and indirect costs for site selection, land acquisition, project/construction management, site characterization, licensing, engineering design, site improvements before construction, utility installations, and construction. These costs include all site characteı zation activities and studies necessary to support the environmental impact reporting process.

\subsubsection{Land Acquisition}

Allowances for land acquisition assumes a land purchase price of approximately $\$ 3,000,000$ to $\$ 4,200,000$. The actual cost of the land may vary depending on location or the availability of suitable State-owned land, prevailing market conditions, and community acceptability. Allowances do not include legal fees or community incentives.

\subsubsection{Project Management}

This cost item includes both labor and supplies, and assumes that the Board will be the overall program manager. Costs are for contractor management, labor, supplies, program plan development, federally mandated quality assurance (QA) plan development and implementation, QA consultant costs, and records management system development costs and implementation. QA plans from disposal facilities in other states are assumed to be available as models.

\subsubsection{Site Selection and Characterization}

Site selection, precharacterization, characterization, baseline monitoring, public involvement, and litigation are covered under this cost item. It is assumed that site selection and precharacterization will use the Commonwealth's geographic information system for initial exclusionary screening. The costs include developing site selection plans, a more comprehensive State geographic database, and technical support for public revicw and participation; performing criteria weighting exercises; and using other states' plans and experience. These costs include $\$ 1,000,000$ for precharacterization of five potential sites.

Full site characterization is assumed for two candidate sites. Site characterization also includes public participation in preparation and development of the site characterization plans, Community Supervisory Committec and public comment resolution, onsite data collection and bascline monitoring, and documentation of the technical and sociological results.

Bascline monitoring activities include the gathering of environmental and health data in addition to the data collected for the basic site characterization. These additional data are necessary for the proposed disposal facility because they establish a foundation for the future assessment of potential impacts upon the environment and human health.

The public involvement cost elements include comprehensive public involvement and development of a community benefits package, information documents and communication program, meeting and hearing support, consultant/contractor support. Community Supervisory 
Committee and Community Advisory Committee support, and other statutorily mandated compensation programs.

Litigation costs are assumed to include contract development, request for proposal, and adjudicating legal challenges to the siting program. This cost component satisfies the need of financial support for community participation in adjudicatory proceedings on the site selection process.

\subsubsection{Licensing/NEPA}

The licensing and National Environmental Policy Act (NEPA) costs are for analysis, documentation, and source term study. These activities build upon the results of previous work from the site selection, characterization, and community involvement efforts. They fulfill the necessary regulatory requirements to define the disposal facility's operational functions.

Source term analyses include an inventory and identification of the characteristics and projections of total quantities of waste during the operational life of the facility. The projections include volume estimates of routine and nonroutine waste, and waste from the decommissioning of major nuclear material uscr facilitics. The source term analyses documentation will be updated at least once during the site selection process. The information will be used for sizing and site selection, site design, disposal method selection, performance assessment, and licensing.

Analysis and documentation includes the preparation of all license support documents: draft environmental impact statement, safety analysis report, and final environmental impact statement. A major part of this task is the performance assessment. This requires complex modeling and computer work to estimate the exposure pathways, radionuclide migration, and radiological dose impacts. These itudies will demonstrate the fulfillment of the tinal site selection, design, and licensing requirements.

\subsubsection{Engineering Design}

Engineering design combines elcments of the source term analysis, the performance assessment, and the site selection and characterization activities to develop the disposal system. This involves the disposal method selection, evaluation of the disposal plan, a screening and qualification study, technical support for public review and participation efforts, development of critical design parameters for site selection, siting design studies, and the final design. A basic performance-based disposal facility design will provide uscful intormation to the candidate site community for selecting the disposal technology.

\subsubsection{Contingencies}

Contingency factors take into consideration the highly technical, complex, and sensitive nature of the siting process, which may result in unplanned cost increases. For example, during site exploration in the site characterization phase, unanticipated site complexities may be discovered that require additional characterization work. Contingencies may also include technical assistance programs for community involvement, public meetings, and independent reviews. 
3.1.6.1 Pre-operations Funding. It is assumed preoperations funds will be raised by issuing bonds. Item WBS-1.6.1 is the sum of the principal and interest on item WBS-1.6. For this report, it is assumed that the bonds are released in three equal amounts in 1996, 1997, and 1998 and due in 2016, 2017 and 2018 (20 years). A rate of 5.5\% is applied using a simplified amortization function. The annual payment of approximately $\$ \mathbf{3 , 7 5 7 , 0 0 0}$ (for small and medium sized facilities) is multiplied by 20 (years) to yield the total bond burden.

\subsubsection{Facility Construction}

Facility construction includes all elements necessary to startup the disposal facility: site preparation; utility installations; site access, administration and waste support buildings; and the initial number of disposal cells. Initially, a small, medium, or large facility will have 5 disposal cells and an extra-large facility will have 15 disposal cells. The features of these facilities are described in Section 2.

A cost factor of $20 \%$ for contractor overhead is applied as an indirect costs to all construction and material costs (Subtotal Item 1.7.5, Table 1). The estimated capital costs for structures and appurtenances are the sum of the following: projected labor hours for the task completion and hourly labor rates, materials, equipment, and supplies. The components of the capital costs are then calculated on a cost item per square foot basis. Areas of specialized installations are about twice the cost of nonspecialized installations. Table 2 is a comparison of the capital cost factors for the front-end and receiving facilities of the different sized disposal sites.

\subsubsection{Construction Management}

Construction management is a $20 \%$ assessment on the total cost of the construction project for the startup facilities. This includes site development, and the buildings for administration, front-end/receiving, waste packaging, and the initial number of disposal cells.

\subsubsection{Contingency for Construction}

The contingency for construction (Item 1.9, Table 1) is a $25 \%$ assessment on the total building costs and the construction management costs. The average amount for construction and management contingencies ranges between $10 \%$ and $40 \%$. This is expected to provide adequate funds for unforeseen problems or delays that may occur on a project of this scope. 
Table 2. Capital cost factors for different front-end and receiving facilities.

\begin{tabular}{lrrrr}
\hline \multicolumn{1}{c}{ Item } & \multicolumn{5}{c}{ Cost factors $\left(\$ / \mathrm{ft}^{2}\right)$} & & \\
\hline Fire system & 1.61 & Medium & Large & Extra-large \\
\hline $\begin{array}{l}\text { Administration/ } \\
\text { laboratory building }\end{array}$ & 142.44 & 1.54 & 1.51 & 1.29 \\
$\begin{array}{l}\text { Warchouse/ } \\
\text { maintenance building }\end{array}$ & 118.02 & 136.69 & 134.95 & 122.64 \\
$\begin{array}{l}\text { Site access } \\
\text { building/roads }\end{array}$ & 162.34 & 111.21 & 110.16 & 91.39 \\
$\begin{array}{l}\text { Truck inspection/ } \\
\text { washout building }\end{array}$ & 193.31 & 156.30 & 151.45 & 134.61 \\
$\begin{array}{l}\text { Waste packaging } \\
\text { building }\end{array}$ & 345.24 & 176.64 & 176.64 & 137.20 \\
$\begin{array}{l}\text { Utility/mechanical } \\
\text { building }\end{array}$ & 347.66 & 318.92 & 318.92 & 254.05 \\
\hline
\end{tabular}

\subsection{WBS 2.0 - Operation Costs}

Operating costs include expenses for daily operations and labor, utilities, materials, cell construction costs, and maintenance over the 30-year operating life of the facility. These estimates represent expenditures for startup, environmental monitoring, equipment replacement, and supply purchases during operations. Operating cost estimates for capital expenditures are factored in the same manner as the facilities' startup construction costs in WBS-1.0. Utilities and materials costs estimates are based on calculations considering daily power, fuel, and materials demands.

\subsubsection{Cell Construction}

Cell construction will be ongoing during facility operations at a rate appropriate to the size of the waste processing facility. Labor and material costs are based on the ILLRWDF and assume that a constant number of cells are built per year of operation. They are: 0.9 cells per year for the small facility (28 total during 29 years); 1.4 cells per year for the medium facility (42 total during 29 years); 2.4 cells per year for the large facility (70 total during 29 years); and 14.8 cells per year for the extra-large facility ( 430 total during 29 years).

\subsubsection{Administration}

A major portion of the administration costs during operation is for personnc The number of personnel were derived from the work force estimates from ILLRWDF. Salary rates were derived from two sources: Dames and Moore's cost study for LLRW disposal sites ${ }^{2}$ and Morrison Knudsen/Chem Nuclear's design package for the ILLRWDF. ${ }^{3}$ Annual salaries listed for different 
job categories are shown in Table 3. The monthly burden rate includes a $100 \%$ contingency. The labor costs for cell construction are part of the annual capital cost estimates and are not calculated with the administration labor costs.

\subsubsection{Operations}

The operations cost estimate is for operating labor, labor materials, and waste processing supplies. The PLCC estimates are based on the assumption that the operating life of the facility is 30 years. For the smaller sites, where two shifts per day may not be justified, a single shift per day or part-time shifts may be used. The mass flow rates for waste processing shown in Figure 4 are based on 30 years of operation.

\subsubsection{Maintenance}

The maintenance cost estimate includes the maintenance materials and maintenance labor costs based on the unit operations for each job. Maintenance labor is calculated as $100 \%$ of the initial equipment installation costs. Maintenance materials (including replacement parts and supplies used during repairs) are calculated at $7 \%$ of initial equipment costs.

\subsubsection{Environmental Monitoring}

Site environmental monitoring during facility operations comprises the majority of monitoring costs. Since the number of monitoring points are site-specific and cannot be determined at this time, the monitoring costs are based on the annual expenditures expected for the ILLRWDF. Depending on the media and analyte, environmental monitoring is performed monthly, quarterly, and annually. Monitoring includes radiological tests in soil, air, plants, animals, groundwater, and surface water. The monitoring program will be designed to satisfy regulations with the conditions of the facility license and terms of the operating contract; provide carly warning of the magnitude and extent of radionuclide migration; and provide reliable environmental data throughout the development, operation, closure, post-closure and institutional control periods.

\subsubsection{Utilities/Materials}

The majority of material costs incurred are for the concrete overpack canisters, sand/cement grout for the canisters, sand backtill for the cells, and personal protective equipment. Utilities include fuel, lighting, and water. Fuel and electricity use is based on the type of machinery and an assumed operational efficiency of $70 \%$. Lighting is calculated based on the square footage of each building and the square footage of outdoor areas. 
Table 3. Annual salary for full-time employees.

\begin{tabular}{|c|c|c|c|}
\hline Position & Annual salary & $\begin{array}{l}\text { Monthly rate } \\
\text { with burden }\end{array}$ & Salary position used \\
\hline Facility manager & $\$ 79,800$ & $\$ 13,300$ & $-b$ \\
\hline Assistant manager & $\$ 49,800$ & $\$ 9,040$ & Project manager ${ }^{c}$ \\
\hline Secretary & $\$ 16,500$ & $\$ 2,750$ & $-b$ \\
\hline Clerk & $\$ 15,000$ & $\$ 2,500$ & $-b$ \\
\hline Document specialist & $\$ 34,800$ & $\$ 5,800$ & Accountant $^{b}$ \\
\hline Business manager & $\$ 42,500$ & $\$ 7,000$ & $\begin{array}{l}\text { General support/project } \\
\text { engineer }^{c}\end{array}$ \\
\hline Accountant & $\$ 34,800$ & $\$ 5,800$ & $-b$ \\
\hline Technical personnel & $\$ 33,900$ & $\$ 5,650$ & Field engineer ${ }^{c}$ \\
\hline Communications & $\$ 45,000$ & $\$ 7,500$ & QA/site engineer ${ }^{b}$ \\
\hline Quality assurance & $\$ 45,000$ & $\$ 7,500$ & QA/site engineer ${ }^{b}$ \\
\hline Environmental management & $\$ 49,800$ & $\$ 8,300$ & Radiological safety officer ${ }^{b}$ \\
\hline Laboratory manager & $\$ 37,800$ & $\$ 6,300$ & $\begin{array}{l}\text { Senior health physics } \\
\text { technician }^{b}\end{array}$ \\
\hline Laboratory technician & $\$ 30,000$ & $\$ 5,000$ & Health physics technician ${ }^{b}$ \\
\hline Warehouseman & $\$ 31,000$ & $\$ 5,160$ & $-{ }^{c}$ \\
\hline Maintenance mechanic & $\$ 38,500$ & $\$ 6,420$ & Mechanic/electrical $^{c}$ \\
\hline Security chief & $\$ 39,600$ & $\$ 6,600$ & $-b$ \\
\hline Guard/access inspection & $\$ 24,600$ & $\$ 4,100$ & $-{ }^{b}$ \\
\hline Truck inspection/washout & $\$ 19,800$ & $\$ 3,300$ & Laborer ${ }^{b}$ \\
\hline Utility mechanic & $\$ 38,500$ & $\$ 6,420$ & Mechanic/electrical $^{c}$ \\
\hline Disposal foreman & $\$ 36,600$ & $\$ 6,100$ & $-{ }^{b}$ \\
\hline Equipment operator & $\$ 31,800$ & $\$ 5,300$ & $-b$ \\
\hline Inspect/assay & $\$ 30,000$ & $\$ 5,000$ & Health physics technician ${ }^{b}$ \\
\hline Treat secondary waste & $\$ 19,800$ & $\$ 3,300$ & Laborer $^{b}$ \\
\hline Grout plant operator & $\$ 19,800$ & $\$ 3,300$ & Laborer $^{b}$ \\
\hline $\begin{array}{l}\text { Personal protective } \\
\text { equipment }\end{array}$ & $\begin{array}{l}\$ 120 \text { each per } \\
\text { person/day }\end{array}$ & - & $-^{c}$ \\
\hline \multicolumn{4}{|c|}{$\begin{array}{l}\text { a. Monthly burden rate is a } 100 \% \text { markup of the monthly salary. } \\
\text { b. Salary information from EG\&G Idaho, Economics of Small Volume LLRW Disposal Facility. }{ }^{4} \\
\text { c. Salary information from ILLRWDF study. }{ }^{2}\end{array}$} \\
\hline
\end{tabular}




\subsubsection{Operator's Profit}

Profit for operating the facility is based on the total annual operating costs. It excludes the annual taxes and contingencies, and includes annual capital improvements, operations, maintenance, salaries, and materials. In accordance with the regulations, the operator has the ability to set waste acceptance fees which are adequate for reimbursing all reasonable expenses Sor facility development and operation. A five percent profit based on the annual operating costs is therefore assumed to be a reasonable charge. The profits are costs that will not be incurred by the state or the operator, but paid by the waste generator as a part of the unit disposal rate.

\subsection{WBS 3.0 - Closure Costs}

Closure costs are based on closure activities during the 10-year period after the facility stops accepting waste. Costs include completion of any open disposal cells, construction of the earthen cap, environmental monitoring, decontamination, decommissioning, and demolition of buildings (except site access/control facilities), and necessary annual utilities, materials, and operational costs.

The vault completion cost is based on the (a) quantity of materials and labor needed to fill and cover any remaining cells, and (b) administration resource demands based on decommissioning projections from the ILLRWDF. Decontamination and decommissioning costs for the nonessential facilities are assumed to be $50 \%$ of the construction costs, except for the administration building. It's cost is assumed to be only $30 \%$ of the construction costs because no decontamination is expected. The annual administration cost is based on the full-time-equivalents necessary to complete all closure activities. Annual operations costs for the closure period are reduced significantly because no waste is coming into the facility and are calculated as $5 \%$ of the operating period annual operations costs. The environmental monitoring plan continues unchanged during the closure period and, therefore, its annual cost remains the same. Supplies and utilities are scaled back based on projected labor, equipment, and facility requirements. Contingency costs for the closure period are calculated as $25 \%$ of all closure costs excluding eperator profit. A 5\% profit is continued during the closure period.

\subsection{WBS 4.0 - Post-Closure Costs}

For this analysis, post-closure is the $\mathbf{3 0 0}$ year period following the closure period in which there is ongoing environmental monitoring and minor site maintenance. Costs for this period include site remediation and maintenance, site security, and environmental monitoring. Once the operator completes the closure activities and the site is returned to the Commonwealth for institutional control, it is expected that a small staff will be able to perform the necessary postclosure activities. 


\subsection{WBS 5.0 - Community Benefits}

Community benefits are to provide incentives to communities that consider hosting a LLRW facility. They will also provide compensation for any negative impacts that may occur to the surrounding areas. Table 4 lists the monetary benefits to the state and host community(ies).

The property taxes to be paid over $\mathbf{4 0}$ years are based on the land purchase value and improvements, such as capital investments for the support facilities and disposal cell construction. Taxes are computed by adding the startup capital costs to an annual increment of improvements for disposal cell construction. The total cost for the cap placement is added to the final cost of capital improvements at the beginning of the closure period. The value of the cap is added in one year for small and medium disposal facilities, over two years for a large disposal facility, and over three years for the extra-large disposal facility.

The taxes are calculated only for the 30 year operating period and the 10 year closure period. Massachusetts law does require taxes to be paid by the state during the institutional control period. But, because of the difficulty in assigning values to the property and remaining structures after transfer to the state, the costs of property taxes during this period are not calculated. The amounts of the incentive payments to the community(ies) were provided by the Board and are self-explanatory. Including property tax outlays based on the capital improvements, the community benefits package is approximately $10 \%$ of the total cost of a disposal facility.

Table 4. Massachusetts community benefits and compensation.

\begin{tabular}{|c|c|c|c|}
\hline Item & Amount $^{\mathbf{a}}$ & Duration & Total amount ${ }^{\mathbf{a}}$ \\
\hline Property taxes & 0.018 per $\$ 1,000 / y r$ & 40 years & $\$ 35,870,000-\$ 284,750,000$ \\
\hline Annual payments & $\$ 240,000 / \$ 400,000$ & First 30 years & $\$ 7,200,000 \$ 12,000,000$ \\
\hline Additional payments & $\$ 150,000 / \$ 150,000$ & $\begin{array}{l}\text { First three } \\
\text { years }\end{array}$ & $\$ 450,000 / \$ 450,000$ \\
\hline $\begin{array}{l}\text { Cornmunity impact } \\
\text { payment }\end{array}$ & $\$ 3,000,000 / \$ 3,000,000$ & One time & $\$ 3,000,000 / \$ 3,000,000$ \\
\hline $\begin{array}{l}\text { Annual neighboring } \\
\text { community payment }\end{array}$ & $\$ 60,000 / \$ 100,000$ & First 30 years & $\$ 1,800,000 / \$ 3,000,000$ \\
\hline $\begin{array}{l}\text { Total community benefits } \\
\text { and compensation }\end{array}$ & - & - & $\$ 48,320,000-\$ 303,200,000$ \\
\hline $\begin{array}{l}\text { a. Two values are expresse } \\
\text { second value is for the extr }\end{array}$ & \multicolumn{3}{|c|}{$\begin{array}{l}\text { The first value is for small, medium, and large disposal facilities. The } \\
\text { arge disposal facility. }\end{array}$} \\
\hline
\end{tabular}




\subsection{Discussion of Results}

PLCC estimates for four sizes of disposal facilities range between $\$ 81,622,000$ to $\$ 137,750,000$ for the initial capital costs; $\$ 10,484,000$ to $\$ 77,232,000$ for annual operating costs; $\$ \$ 23,445,000$ to $\$ 3,014,745,000$ for total costs; and $\$ 215 / \mathrm{ft}^{3}$ to $\$ 499 / \mathrm{ft}^{3}$ for unit rate disposal costs (refer to Table ES-1). The PLCC estimates are based on a preliminary feasibility study of an unbuilt waste disposal facility. A preliminary feasibility study is composed of detailed architectural, civil engineering and geotechnical investigations and designs. A preliminary feasibility study can yield a cost estimate within $20 \%$ of actual expenditures.

The PLCC estimates presented here are based on these engineering estimates. However, actual cost of developing a LLRW disposal facility in Massachusetts may vary significantly from these estimates for several reasons. First, no state-of-the-art facility has been buili to verify the cost bases used. Second, the assumptions in this cost study differ significantly from those embedded in the engineering estimates. Third, and most important, the underlying assumptions of this analysis are subject to change by the Board as it decides how it will manage Massachusett's waste and the specific characteristics the actual disposal facility will have. Therefore, the results of this cost study are not absolute and should only be used to compare the relative costs of the options presented.

The PLCC estimates show that as the size of the facility increased by $43 \%$ from small to medium, $60 \%$ from medium to large, and $483 \%$ from large to extra-large, the total cost increased much less $-23 \%, 35 \%$, and $278 \%$, respectively. This difference is reflected in Table ES- 1 as a decreasing unit cost (cost per cubic foot). The percentage of total cost represented by each major category also changed except for post-closure and community benefits and compensation, which stayed rather constant between $2-3 \%$ and $9-10 \%$, respectively. The pre-operations a.nd closure costs decreased from $21 \%$ to $6 \%$ and $7 \%$ to $4 \%$, respectively. On the other hand, operations costs increased from $60 \%$ to $77 \%$. These findings suggest that all broad cost categories, except for operations are relatively independent of size and that "economies of scale" help level-out or reduce their relative contribution to the total cost.

This information can be taken one step farther by standardizing cost changes to changes in volume. For example, if a cost changes $75 \%$ with a $150 \%$ change in volume, the standardized cost change to volume is computed as $75 \% / 150 \%$ or 0.50 . This means that the cost changes half as fast as the volume. When applied to this analysis, the increase in size from the small to the extra-large facility increased the total cost about $39 \%$ for each $100 \%$ increase in volume. As would be expected, pre-operations and closure costs were affected least and averaged a 5\% and $20 \%$ increase, respectively, for each $100 \%$ increase in volume. This indicated, however, that postclosure costs are more sensitive than either operations or community benelits and compensation, increasing $57 \%$ compared to $52 \%$ and $43 \%$, respectively, for each $100 \%$ increase in volume. This fact was likely masked above because of the small contribution post-closure costs make to the overall cost of the facility $(2-3 \%)$.

For the assumptions used in this report, generally this means that not only is "larger cheaper" on a unit cost basis, but also that operations, post-closure, and community benefits and compensation costs increase faster than other cost categories with increases in facility size. This will be explored more fully in the sensitivity analysis section of this report. 


\subsection{Sensitivity Analysis}

The sensitivity analysis was performed on the base case PLCC estimates by varying several different cost components. Five components were found to have the largest impact on unit and total costs. These were the staffing demands, costs incurred by the State, capital costs, materials costs (canisters, sand, and cement), and a fixed salary for all staff. The bar graphs of the five cost modifications depict the unit disposal cost information in a consistent format. From the front to the back of each graph, each set of bars illustrate the relative changes for each size facility's cost modification. For each range of modifications - 50\% decreasc, $50 \%$ increase, $100 \%$ increase the positions and the shading of the bars remain constant. Modifications representing $50 \%$ cost decreases are shown first, $50 \%$ cost increases are shown second, $100 \%$ cost increases are shown third, and the base cases are shown last. For the changes in base salary (Figure 6), two bars are shown for each facility size with the base case costs at the front of the graph.

The greatest effect on the unit disposal rate was from salary and staffing changes. These changes were calculated as decreases or increases to the overall staffing demands or as a fixed salary rate to the base level staffing demands. For a $100 \%$ increase in staffing, the unit disposal rate increased by over $30 \%$ for the small, medium, and large disposal facilities, and $18 \%$ for the extra-large disposal facility (Figure 5). For all salaries fixed at the same amount, the unit disposal rate increased by $33 \%$ for the small and medium facilities, $29 \%$ for large facilities, and $19 \%$ for the extra-large facility (Figure 6).

The next largest influence in the unit disposal rates are from increases in capital costs (Figure 7). These changes decreased or increased the capital costs of the land purchase price, all operational facilities, and the cost of the disposal cells and vault caps. A $100 \%$ gain in the capital costs increases the unit disposal rates $24 \%$ for the small disposal facility and $33 \%$ for the extralarge disposal facility. A $100 \%$ increase in capital costs is the most significant impact on unit disposal rates for the extra-large and large facilities. In addition, a 50\% decrease in the capital costs resulted in the largest drop in unit disposal rates for the extra-large facility, 17\%. The capital cost variations also had the greatest effect on the estimated taxes. Compared to the base case, a $100 \%$ capital cost increase resulted in taxes about two times greater for all sizes of disposal facilities.

Unit disposal rates were least affected by variations in the materials costs (Figure 8) or preoperational costs (Figure 9). Materials costs modificd the cost of the concrete waste canisters $(\$ 1,500$ each base price) and the sand and cement used for grouting the waste $(\$ 0.03 / \mathrm{b}, \$ 0.05 / \mathrm{b}$, respectively). The preoperational costs - funds to be raised by the State - were simply reduced by $50 \%$ ( $\$ 22$ million) or increased by $100 \%$ ( $\$ 90$ million). Taxes calculated for community benefits and compensation were revised accordingly. A $100 \%$ increase in the materials costs increased the unit disposal rates by $6 \%, 7 \%$, and $8 \%$ for small, medium and large facilities, respectively, and by $14 \%$ for the extra-large facility. With changes in the state cost, the unit disposal costs also increased with increasing facility size. These increases costs ranged from $15 \%$ to $8 \%$ for the small, medium and large facilities, to less than $1 \%$ for the extra-large facility with a $100 \%$ increase in preoperational costs. 


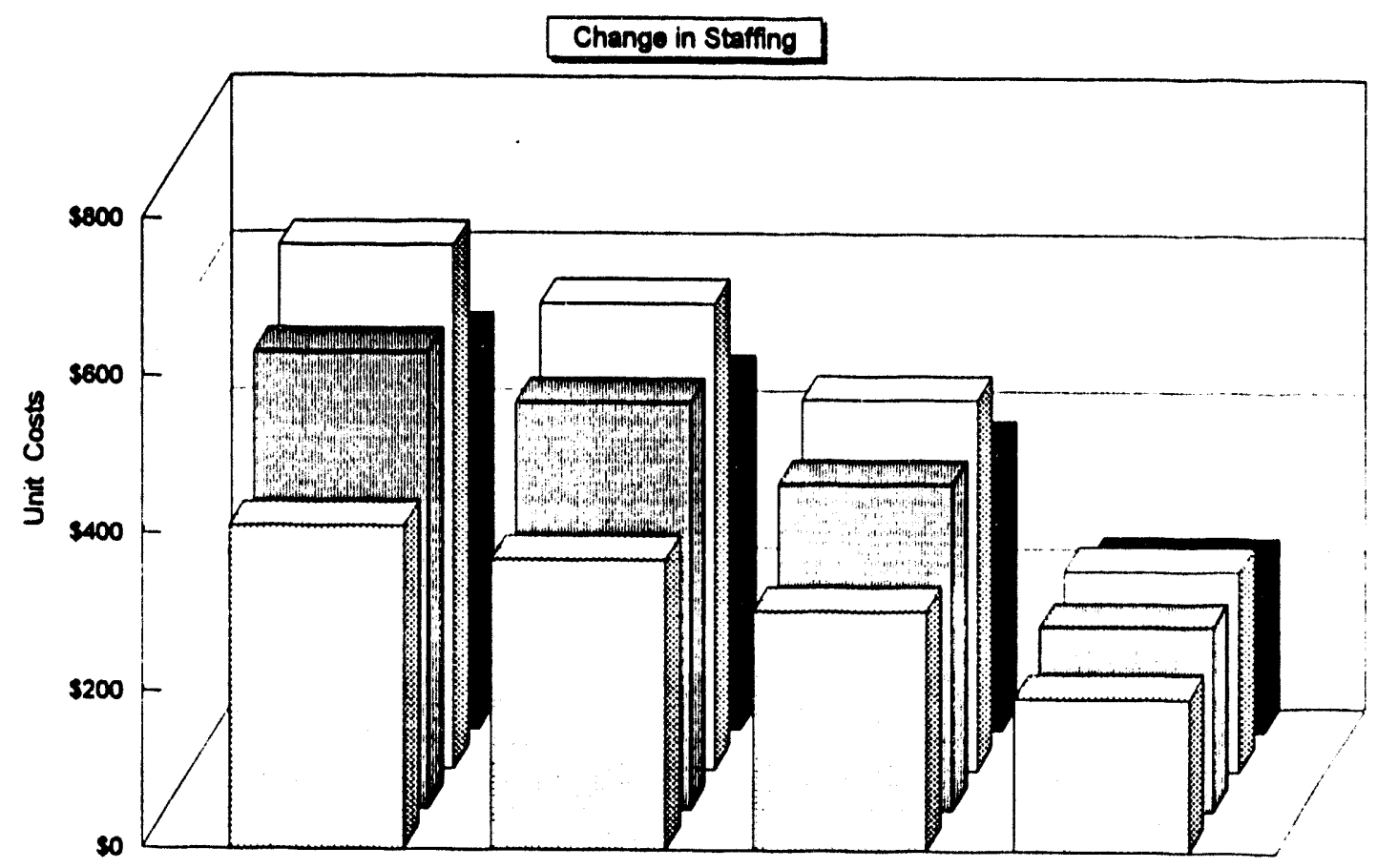

\begin{tabular}{|l|c|c|c|c|}
\hline COST ELEMENT & SMALL FAC. & MEDIUM FAC. & LARGE FAC. & X-LARGE FAC. \\
\hline 0 50\% Decrease & $\$ 411$ & $\$ 369$ & $\$ 305$ & $\$ 195$ \\
\hline $50 \%$ Increase & $\$ 581$ & $\$ 518$ & $\$ 416$ & $\$ 235$ \\
\hline $0^{100 \% \text { Incresse }}$ & $\$ 668$ & $\$ 593$ & $\$ 471$ & $\$ 255$ \\
\hline Baso Caso & $\$ 499$ & $\$ 44$ & $\$ 362$ & $\$ 215$ \\
\hline
\end{tabular}

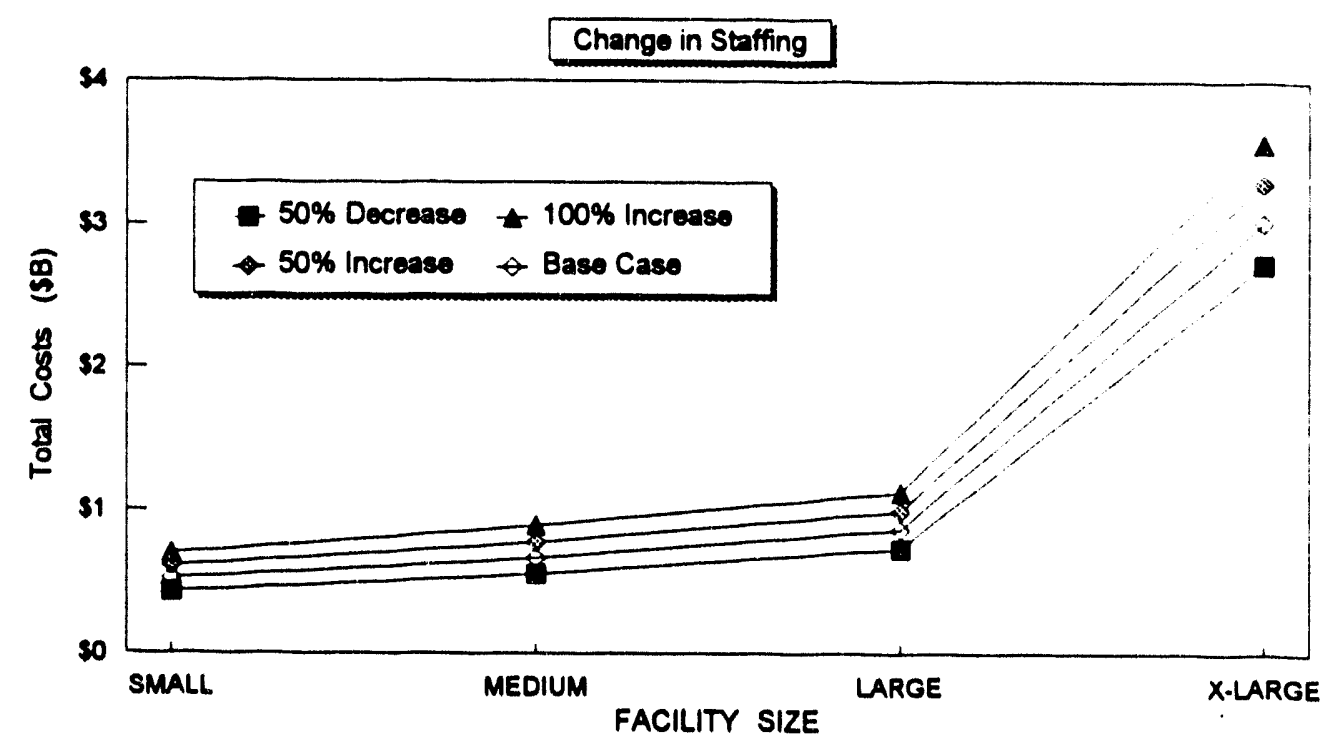

Figure 5. Change in staffing. 

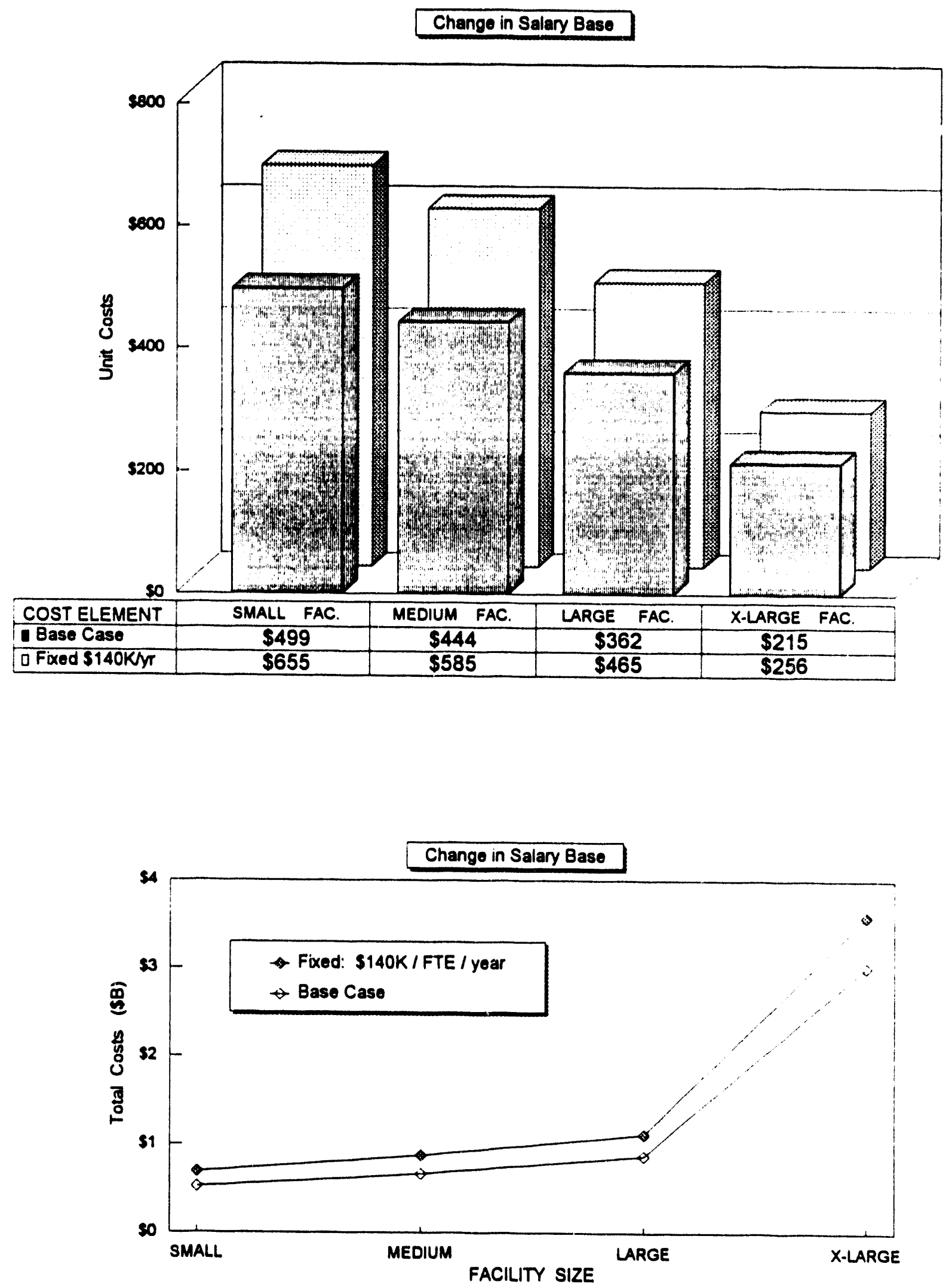

Figure 6. Change in salary base. 


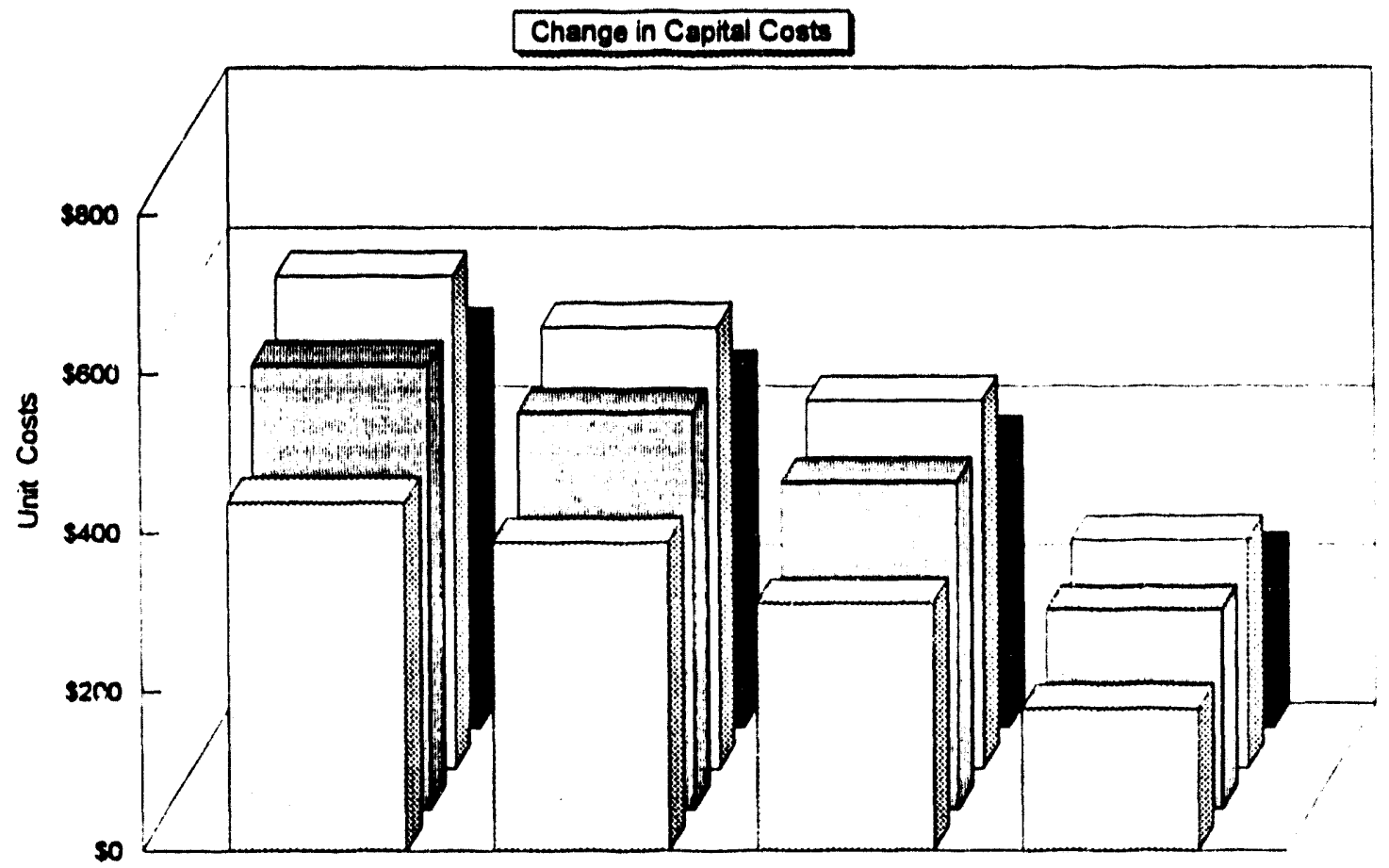

\begin{tabular}{|l|c|c|c|c|}
\hline COST ELEMENT & SMALL FAC. & MEDIUM FAC. & LARGE FAC. & X-LARGE FAC. \\
\hline o $50 \%$ Decrease & $\$ 439$ & $\$ 388$ & $\$ 312$ & $\$ 178$ \\
\hline $50 \%$ Increase & $\$ 560$ & $\$ 501$ & $\$ 413$ & $\$ 252$ \\
\hline $0100 \%$ Increase & $\$ 621$ & $\$ 557$ & $\$ 464$ & $\$ 289$ \\
\hline Base Case & $\$ 499$ & $\$ 444$ & $\$ 362$ & $\$ 215$ \\
\hline
\end{tabular}

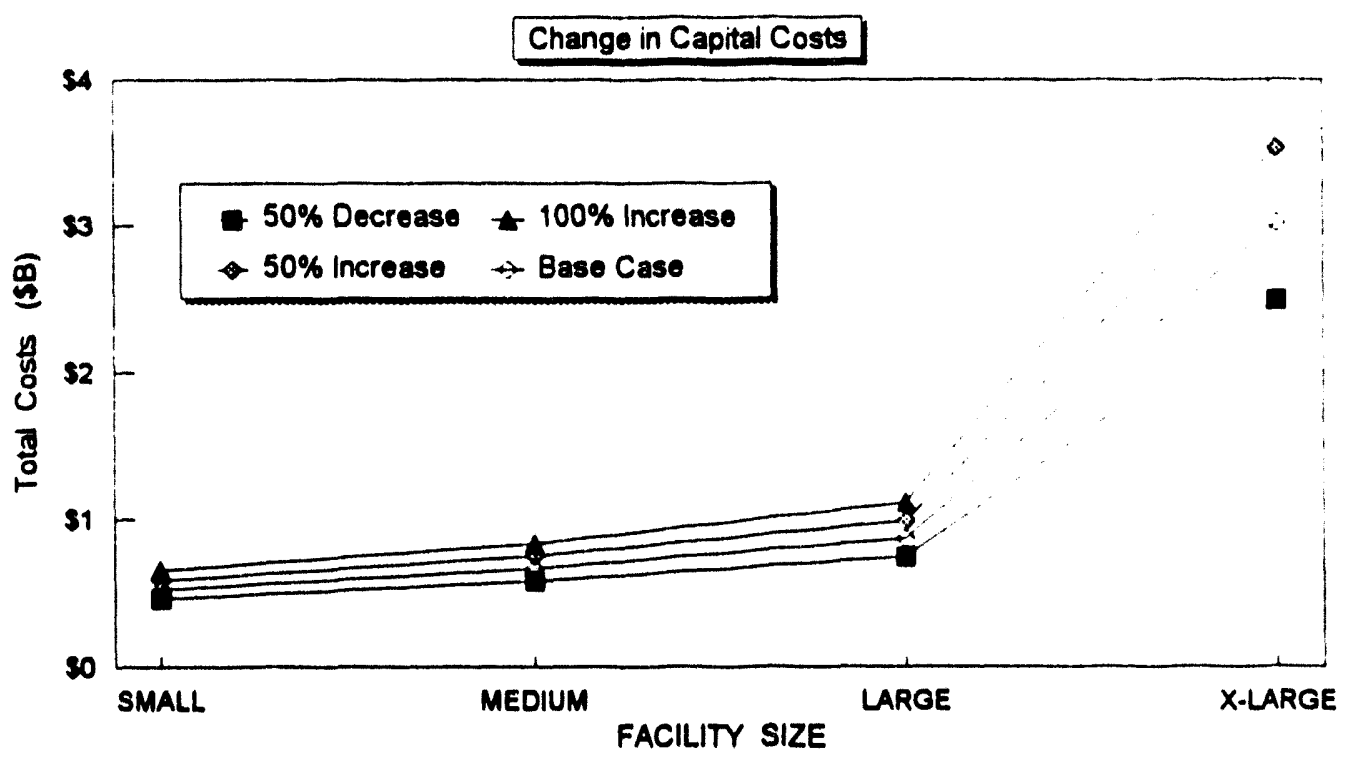

Figura 7. Change in capital costs. 


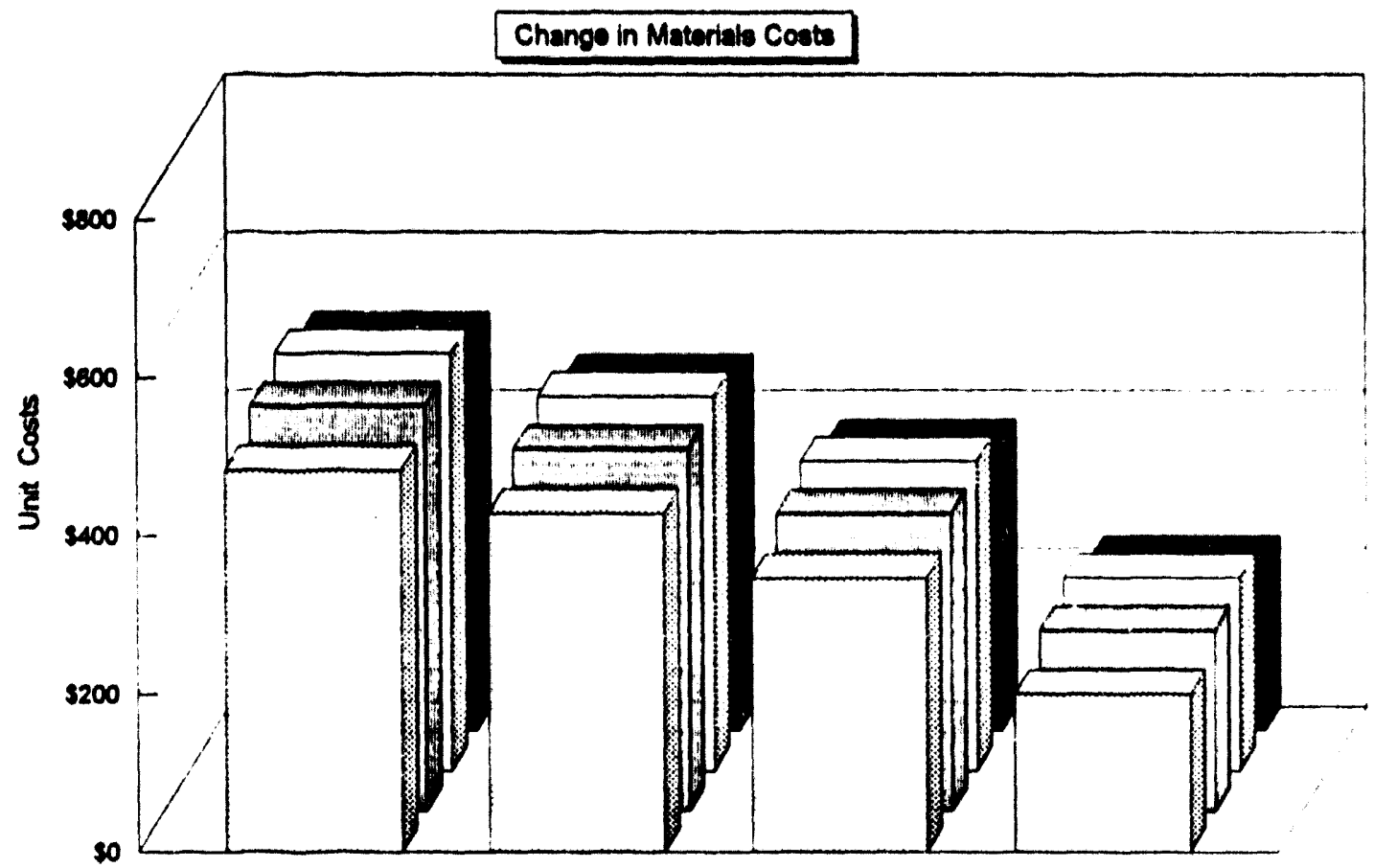

\begin{tabular}{|l|c|c|c|c|}
\hline COST ELEMENT & SMMLL FAC. & MEDIUM FAC. & LARGE FAC. & X-LARGE FAC. \\
\hline $0^{50 \% \text { decrease }}$ & $\$ 483$ & $\$ 429$ & $\$ 347$ & $\$ 200$ \\
\hline $1^{50 \% \text { increese }}$ & 3514 & $\$ 459$ & $\$ 37$ & $\$ 230$ \\
\hline $0^{100 \% \text { increase }}$ & 3529 & $\$ 474$ & $\$ 392$ & $\$ 245$ \\
\hline
\end{tabular}

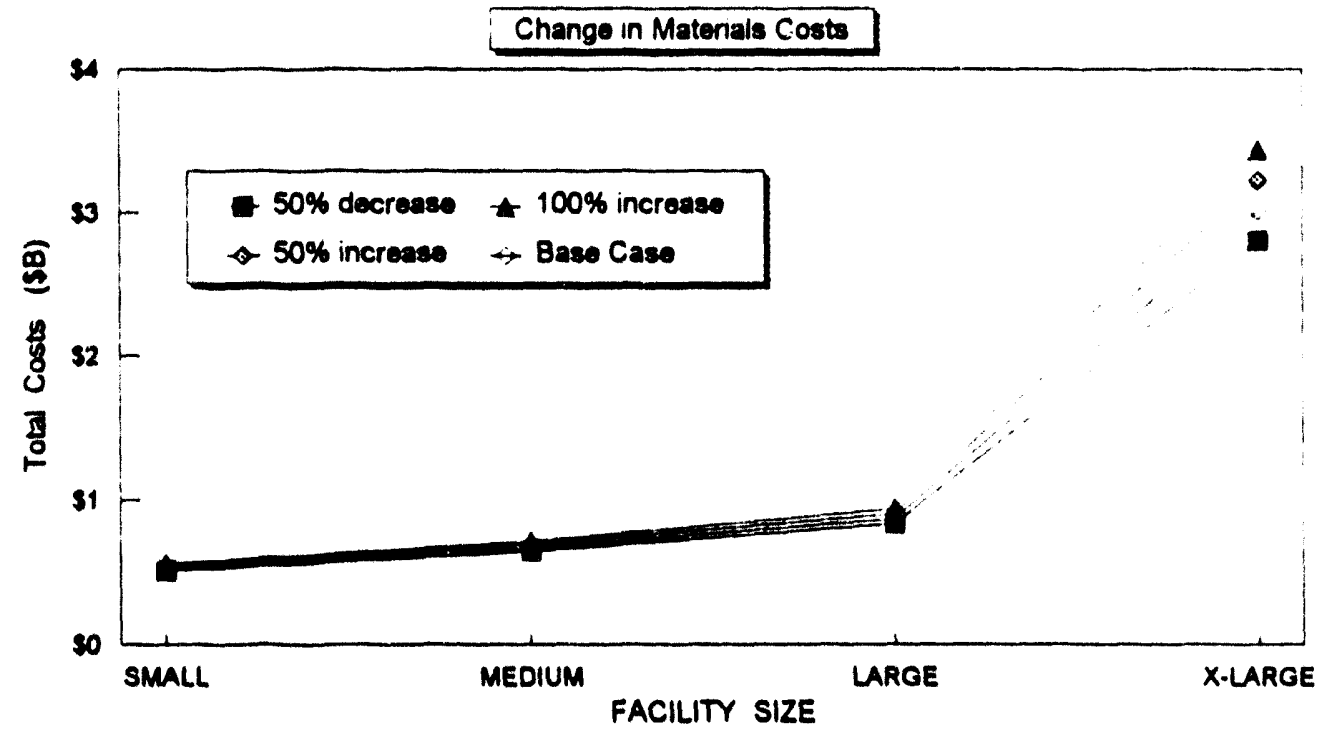

Figure 8. Change in materials costs. 


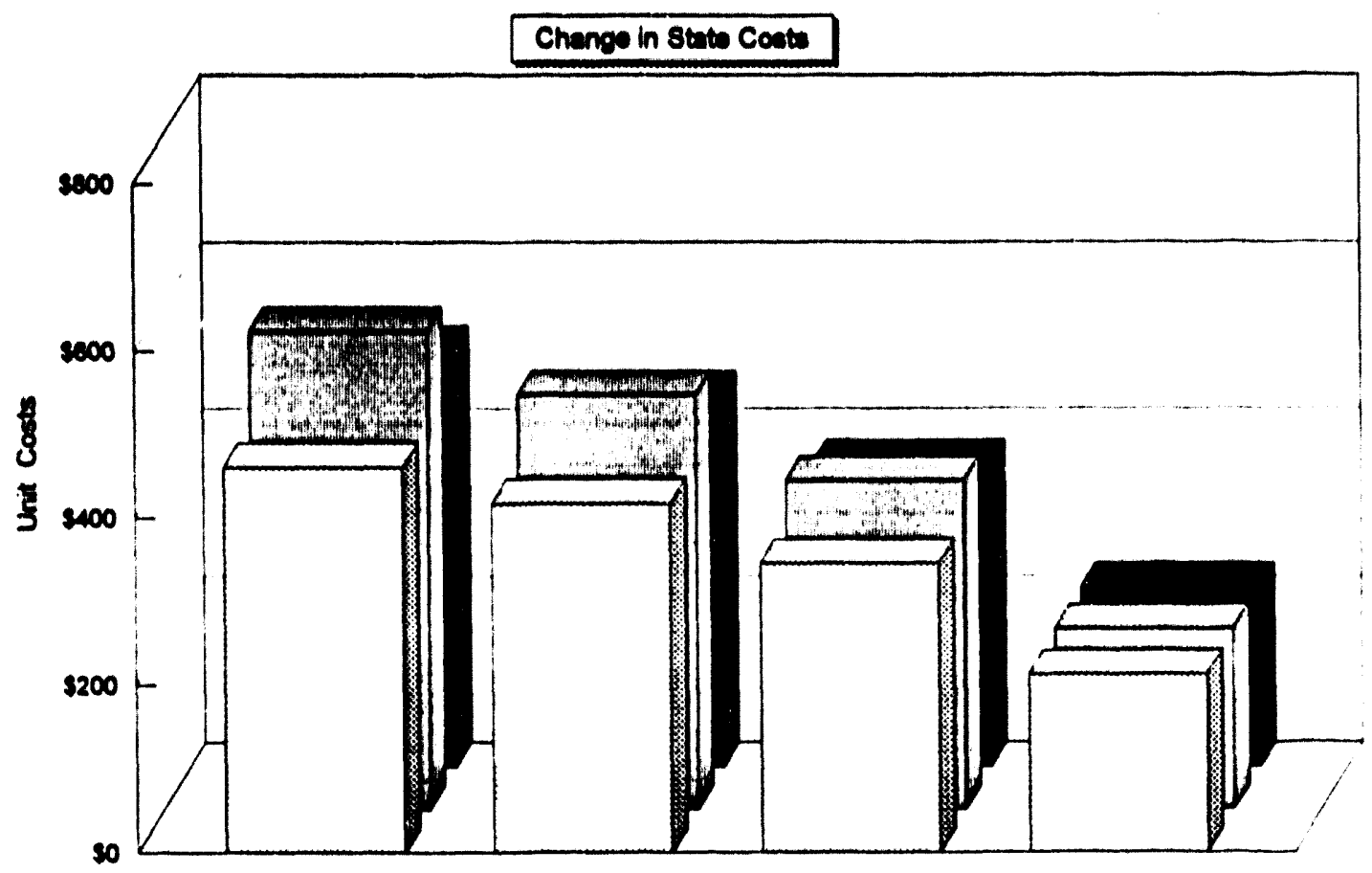

\begin{tabular}{|l|c|c|c|c|}
\hline COST ELEMENT & SMALL FAC. & MEOIUM FAC. & LARGE FAC. & X-LARGE FAC. \\
\hline $0 \$ 22$ million & $\$ 461$ & $\$ 418$ & $\$ 340$ & $\$ 212$ \\
\hline$\$ 90$ million & $\$ 572$ & $\$ 48$ & $\$ 394$ & $\$ 216$ \\
\hline Baso Case & $\$ 490$ & $\$ 44$ & $\$ 302$ & $\$ 215$ \\
\hline
\end{tabular}

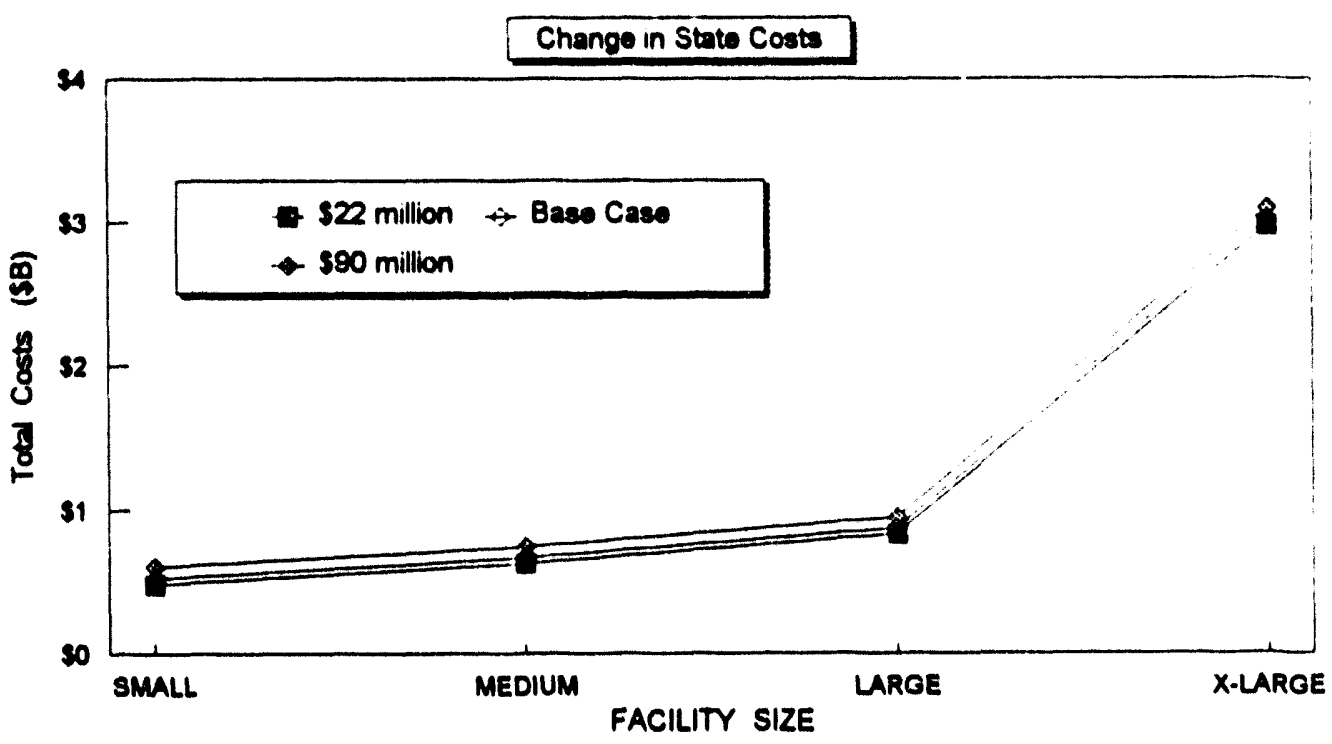

Figure 9. Change in state costs. 


\section{CONCLUSIONS}

The PLCC estimates for various sizes of disposal facilities show relatively minor cost increases from the small, to the medium, and the large disposal facilities compared with the extralarge disposal facility. PLCC increases from the large to the extra-large facility is much greater because of the greater size of the facility. All areas of operations, labor, and maintenance for the extra-large disposal facility costs five to ten times more than the three smaller disposal facilities and provide a six to thirteen fold increase in disposal capacity.

The PLCC estimates indicate that the expenditures incurred during the operational period of the disposal facilities will be between $60 \%$ to $77 \%$ of the total costs. About $50 \%$ of the annual budget during the operating period will be for administrative costs due to labor and for disposal cell construction. Therefore, changes in the actual costs for these two components will have large impacts on operating costs, taxes, the total PLCC, and unit disposal rates. For all disposal facilities, the estimated taxes over 40 years (30) years for facility operations and 10 years for closure) are approximately $10 \%$ of the total facility costs. Variations in the capital costs result in similar changes in the taxes, i.e., a doubling of the capital costs doubles the tax burden. Compared to capital and labor expenditures, the total facilities costs are least affected by differences in costs of land acquisition. materials, or supplies.

In order to select the optimum disposal option, additional analyses should focus on evaluating uncertainties for operating expenditures. The sensitivity analysis shows that a change in labor or construction costs can significantly impact the total PLCC estimate. Materials and site acquisition costs comprise the smallest percentage of a facility's expenditures. The operational period is the only time of revenue generation, consequently, those revenues must apply to expenses to be incurred over the entire life of the facility. Therefore, the labor and capital cost during the 30 year operating period should be evaluated carefully during the planning and linal design stages since they are the two most important factors affecting available monetary resources for long-term management during the closure and institutional control periods. 


\section{REFERENCES}

1. R. S. Means Company, Inc., Means Building Construction Cost Data, 50 $0^{\text {th }}$ Annual Edition for 1992, Phillip R. Waier, editor, 1991.

2. Morrison Knudsen/Chem Nuclear Services, "Chapter 3: Illinois Low-Level Radioactive Waste Disposal Facility; Design, Construction and Capital Cost," from Illinois Low-Level Radioactive Waste Disposal Facility Application, May 1991.

3. Morrison Knudsen Corporation, Estimating Manual, Morrison Knudsen Environmental Services Division, two volumes, February 1993.

4. EG\&G Idaho, Inc., 1993, Economics of a Small-Volume Low-Level Radioactive Waste Disposa! Facility, prepared by Dames \& Moore for Idaho National Engineering Laboratory, EG\&G Idaho, Inc., DOE/LLW-170, April 1993. 
Appendix A

PLCC Summary Tables

A-1 


\section{Appendix A}

\section{PLCC Summary Tables}

This appendix presents summary cost tables of the PLCC estimates for the sensitivity analysis modifications. Table A-1 lists the factors that were varied for the sensitivity analysis.

Table A-1. Sensitivity analysis variations.

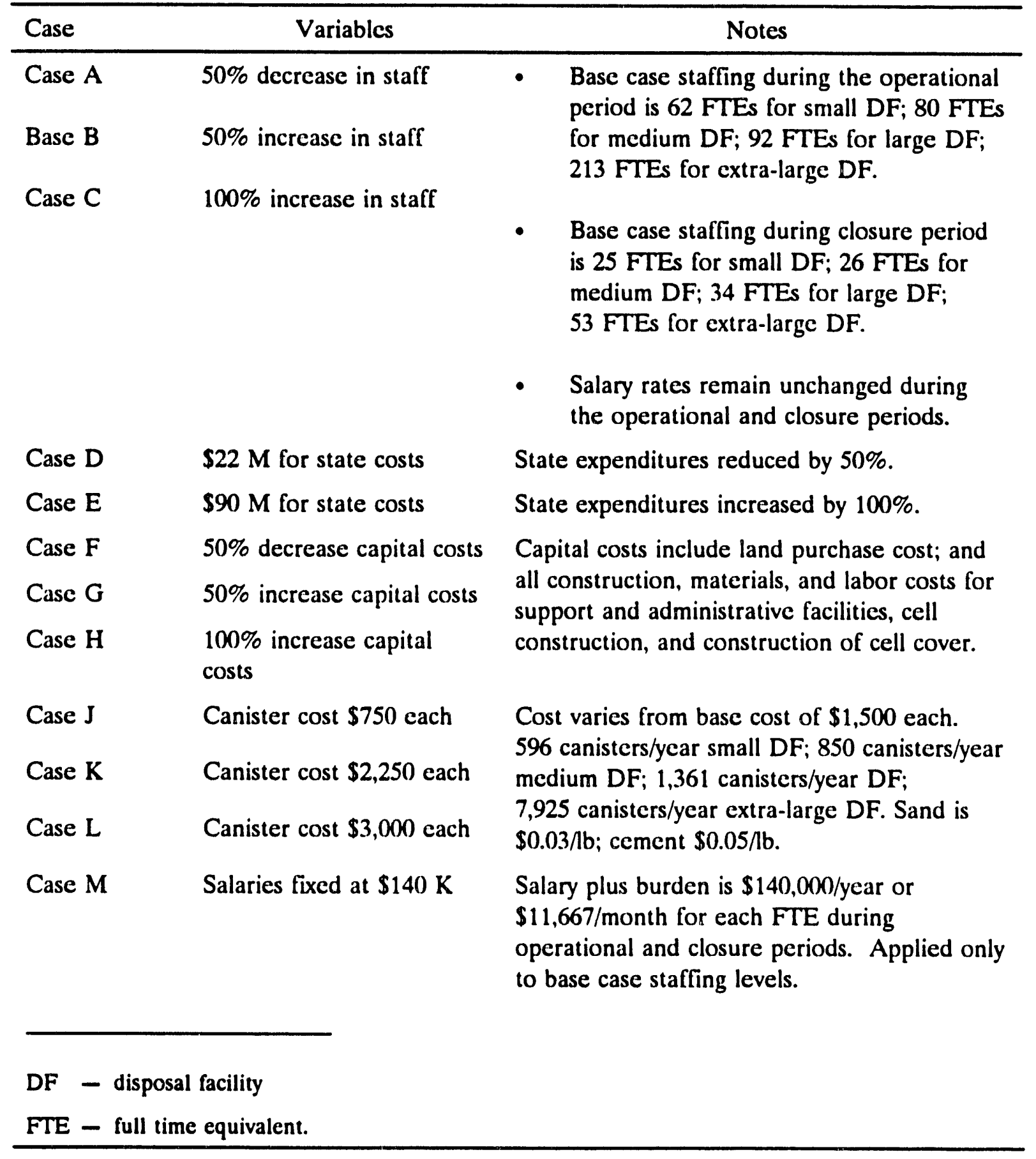




\section{Data Presentation}

Following are the PLCC estimate summary tables. Each cost item is listed in the format of the WBS from the scope of work. The first table is a summary of all totals of the WBS elements for each size of disposal facility and for each modified cost factor. Subtotals and totals for each WBS element are highlighted in bold-face type. 
Summary of WBS Cost Totals (S1000) for Massachusetts Disposal Facinties

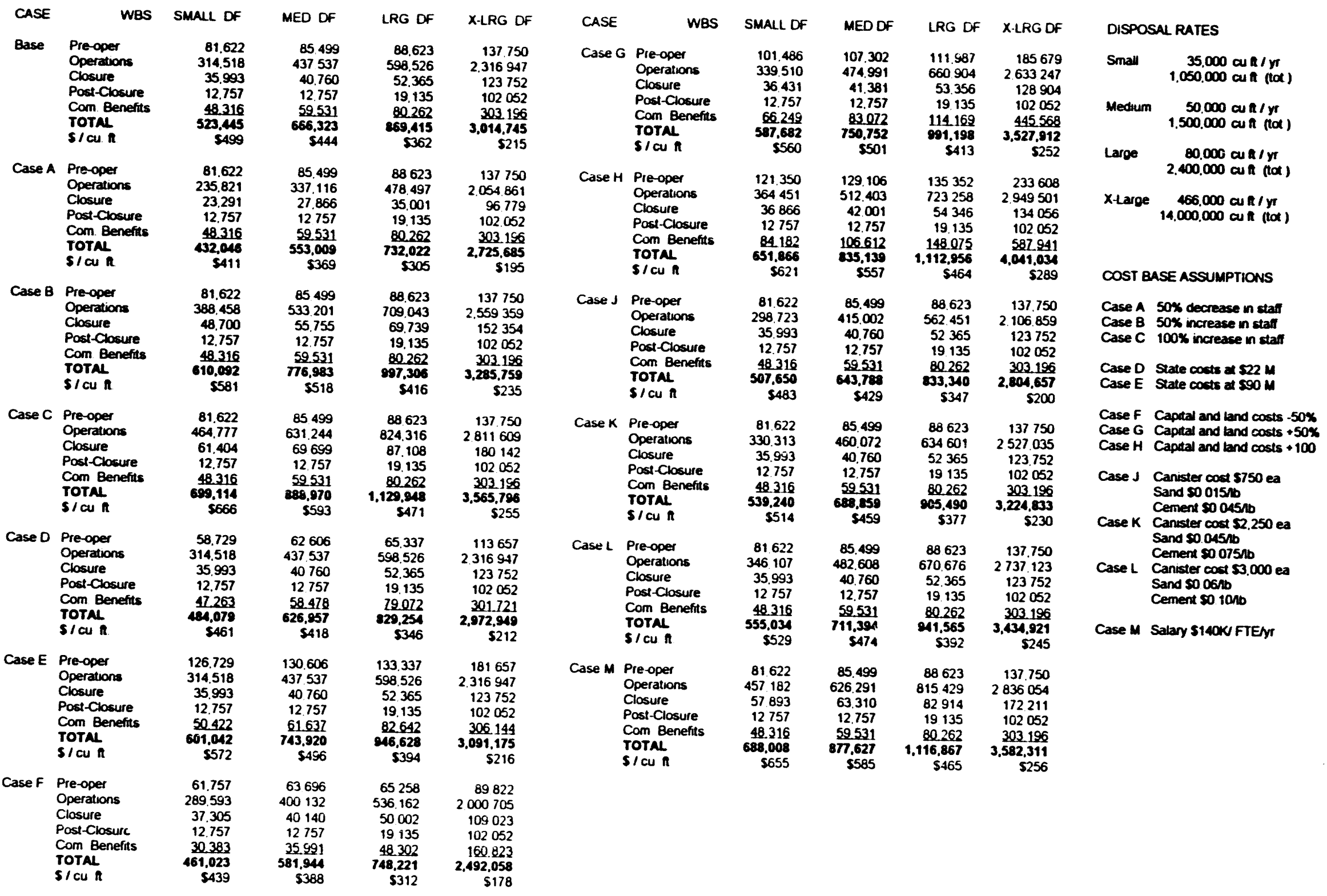


WORK BREAKDOWN STRUCTURE BASE CASES

PLCC Estimatios for 4 Sizes of Disposal Facilltes

1.0 Pro-Operation

1.1 Land Acquisition

1.2 Project Management

1.2.1 Labor

1.2.2 Supplies

1.3 Sth Selection / Charactorlation

1.3.1 Situ Selection / Pre-characterization

1.3.2 Public Involvement

1.3.3 Charectorization

1.3.4 Litigation

1.3.5 Baselline Monitioring

1.4 Licensing / NEPA

1.4.1 Source Term

1.4.2 Analysis/Documentation

1.5 Engincering Dosion

1.6 Contingencies (for Homs 1.1 to 1.5)

Subtotal (thoms 1.1 to 1.6)

\begin{tabular}{|c|c|c|c|}
\hline $\begin{array}{r}\text { Small } \\
(\times \$ 1000)\end{array}$ & $\begin{array}{c}\text { Medium } \\
(x \$ 1000)\end{array}$ & $\begin{array}{r}\text { Large } \\
(x \$ 1000)\end{array}$ & $\begin{array}{r}\text { X-Large } \\
(x \$ 1000)\end{array}$ \\
\hline 3,000 & 3,000 & 3,393 & 4,200 \\
\hline $\begin{array}{r}4,000 \\
187\end{array}$ & $\begin{array}{r}4,000 \\
187\end{array}$ & $\begin{array}{r}4,000 \\
187\end{array}$ & $\begin{array}{r}4,000 \\
187\end{array}$ \\
\hline $\begin{array}{r}2,300 \\
5,000 \\
11,000 \\
1,000 \\
1,500\end{array}$ & $\begin{array}{r}2,300 \\
5,000 \\
11,000 \\
1,000 \\
1,508\end{array}$ & $\begin{array}{r}2,300 \\
5,000 \\
11,000 \\
1,000 \\
1,508\end{array}$ & $\begin{array}{r}2,300 \\
5,000 \\
11,000 \\
1,000 \\
1,508\end{array}$ \\
\hline $\begin{array}{r}250 \\
8,377 \\
4,500 \\
3,771 \\
44,893\end{array}$ & $\begin{array}{r}250 \\
8,377 \\
4,500 \\
3,771 \\
44,893\end{array}$ & $\begin{array}{r}250 \\
8,377 \\
4,500 \\
3,771 \\
45,286\end{array}$ & $\begin{array}{r}250 \\
8,377 \\
4,500 \\
3,771 \\
46,093\end{array}$ \\
\hline 78,132 & 78,132 & 76,790 & 77,14 \\
\hline $\begin{array}{r}1,498 \\
1,921 \\
2,348 \\
7,931 \\
6,707 \\
20,405 \\
4,081 \\
24,486 \\
4,897 \\
7,346\end{array}$ & $\begin{array}{r}1,732 \\
2,377 \\
3,062 \\
7,931 \\
7,457 \\
22,559 \\
4,512 \\
27,071 \\
5,414 \\
8,121\end{array}$ & $\begin{array}{r}2,221 \\
2,493 \\
3,062 \\
7,931 \\
8,368 \\
24,076 \\
4,815 \\
28,891 \\
5,778 \\
8,687\end{array}$ & $\begin{array}{r}4,487 \\
5,544 \\
6,555 \\
19,640 \\
14,696 \\
50,921 \\
10,184 \\
61.105 \\
12,221 \\
18,331\end{array}$ \\
\hline 81,622 & 86,499 & 88,623 & 137. \\
\hline
\end{tabular}

1.6.1 Intereat and Principal on State Bonds (due 2018)

1.7 Facility Construction

1.7.1 Administration

1.7.2 Front End / Recoiving

1.7.3 Wasto Packaging

1.7.4 Disposal Unit

1.7.5 Site Development Subtotal Direct Costs (ttems 1.7.1 to 1.7.5)

1.7.6 Contrector Overhead Fee (Indirect Cost) Subtotul Facility Construction (them 1.7)

1.8 Construction Management

1.9 Contingency for Construction (for homs $1.7 \& 1.8$ )

Total Pre-Operational Costs

86,499

1.481

4.151

2,221

5,208

2,807

2.1.2 Administration (FTE)

2.1.3 Operations

2.1.4 Maintenance

2.1.5 Environmental Monitoring

2.1.8 Uvilites / Materiat:

Subtotal Annual Operational Costs (tiem 2.1)

2.1.7 Operator's Profit (5\% of annual costs)

Total Operational Costs over 30 yeare

$1,040 \quad 2,807$

$275 \quad 275$

9.985

3,224

13.890

695

314,618

$\mathbf{4 3 7 , 6 3 7}$

3.701

5.994

4,159

259

413

4.475

19.001
950

3.0 Closure

3.1 Cover Emplacement

671

955

1,524

7,926

3.2.1 Administration

3.2.2 Front-End Receiving

3.2.3 Wasto Packaging

3.3 Administrution (FTE)

3.4 Operattons

3.5 Environmental Monitoring

3.6 Supplies / Uatilites

3.7 Contingency (for thams 3.1 to 3.6)

3.8 Operator's Profit (5\% $x$ annual costs (items 3.1-3.6))

Total Ciosure Cost

4.0 Post-Closure

4.1 Environmental Monitoring

4.2 Sito Remediation

4.3 Security

4.4 Maintenance

Total Post-Closure Costs

5.0 Community Bencfits and Compensation

5.1 Property Taxes (botal over 40 years)

5.2 Annual Payments (totel over 30 years)

5.3 Additional Payments (totel over 3 yoars)

5.4 Community Impact Payment

5.5 Annusl Neighboring Community

Payments - (botal over 30 years)

Total Community Benents a Compensation Coste

TOTAL FACILIY COSTS (ltams 1.0 to 6.0)

unit costs (\$1000/ cu fi)
449

981

1.174

18.154

920

2.750

2,609

6.922

1,384

36,993

520

1.189

1,531

19,054

1.403

2,750

3,952

2838

1,568

40,760

668

1,247

1,531

24.101

2,079

4,125

5,008

10.070

2,014

62,368

1,346

2,772

3,277

36,924

9,945

22,000

11,004

23.798

4,760

123,762

5,400

5,400

8,100

8.160

1.623

1252

19,136

43,200

43,520

8,656

6.676

12,767

102,062

12,767

47.081

7,200

67.81

284,746

7,200

450

3,000

450

3,000

450

3,000

12,000

450

3,000

1,800

1,800

1,800

3,000

4.316

62.831

$80.262 \quad 303.19$

623,446

686,323

$889,4163,014,746$

$0.36 \quad 0.22$ 
WORK BREAKDOWN STRUCTURE CASE A

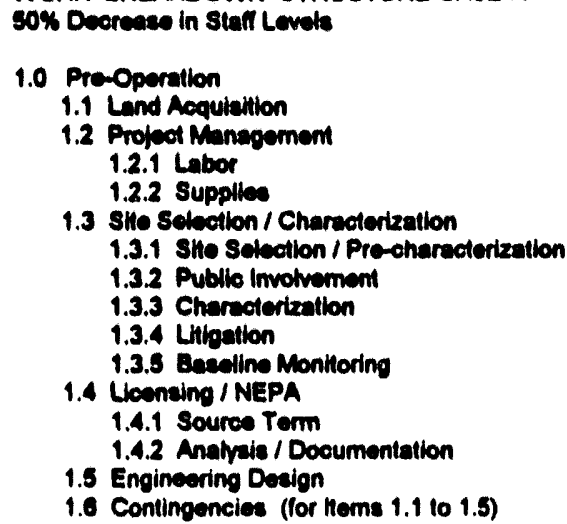

Total Pre-Operational Costs

\begin{tabular}{|c|c|c|c|}
\hline $\begin{array}{l}\text { Small } \\
(1000)\end{array}$ & $\underset{(x+1000)}{\text { Medlum }}$ & $\begin{array}{r}\text { Largo } \\
(x \$ 1000)\end{array}$ & $\begin{array}{c}x \text {-Large } \\
(x \$ 1000)\end{array}$ \\
\hline 3,000 & 3,000 & 3,303 & 4,200 \\
\hline $\begin{array}{r}4000 \\
187\end{array}$ & $\begin{array}{r}4000 \\
187\end{array}$ & $\begin{array}{r}4000 \\
187\end{array}$ & $\begin{array}{r}4000 \\
187\end{array}$ \\
\hline $\begin{array}{r}2,300 \\
5,000 \\
11,000 \\
1,000 \\
1,500\end{array}$ & $\begin{array}{r}2,300 \\
8,000 \\
11,000 \\
1,000 \\
1,508\end{array}$ & $\begin{array}{r}2,300 \\
9,000 \\
11,000 \\
1,000 \\
1,608\end{array}$ & $\begin{array}{r}2,300 \\
5,000 \\
11,000 \\
1,000 \\
1,508\end{array}$ \\
\hline $\begin{array}{r}250 \\
8,377 \\
4.500 \\
3.771 \\
44.893\end{array}$ & $\begin{array}{r}250 \\
6,377 \\
4,500 \\
3,771 \\
41,893\end{array}$ & $\begin{array}{r}250 \\
8,377 \\
4,500 \\
3,771 \\
45,286\end{array}$ & $\begin{array}{r}250 \\
8.377 \\
4.500 \\
3.771 \\
46.093\end{array}$ \\
\hline 76,132 & 76,132 & 76,790 & 77.141 \\
\hline $\begin{array}{r}1,498 \\
1,921 \\
2,348 \\
7,931 \\
6,707 \\
20,405 \\
4,081 \\
24,486 \\
4,897 \\
7,346\end{array}$ & $\begin{array}{r}1,732 \\
2.377 \\
3,062 \\
7,931 \\
7,457 \\
22,559 \\
4,512 \\
27.071 \\
5,414 \\
8,121\end{array}$ & $\begin{array}{r}2,221 \\
2,493 \\
3,062 \\
7,931 \\
8,368 \\
24.076 \\
4,815 \\
28,891 \\
5,778 \\
8,687\end{array}$ & $\begin{array}{r}4,487 \\
5,544 \\
6,555 \\
19,640 \\
14,696 \\
50,921 \\
10.184 \\
61.105 \\
12,221 \\
18.331\end{array}$ \\
\hline 81,68 & 88,499 & 88,623 & 137.750 \\
\hline
\end{tabular}

$2,084,861$

8,100

8,160

1,623

43,200

1,082

835

1.252

43,520
8,656

835

12.767

19,136

6.678

12,767

102,062

5.0 Community Benefits and Compeneation 5.1 Property Taxes (total over 40 yeara)

5.2 Annual Peyments (lotal over 30 years)

5.3 Addilional Payments (lolal over 3 yeara)

5.4 Community Impect Payment

5.5 Annud Neighboring Community Pormente (lotal over 30 years) Total Community sememts 8 Compensation Costs

TOTAL FAcILIT costs (nems 1.0 to 6.0)

UNIT costs (\$1000/cun)

\begin{tabular}{|c|c|c|c|}
\hline $\begin{array}{r}36,860 \\
7,200 \\
460 \\
3,000\end{array}$ & $\begin{array}{r}47,081 \\
7,200 \\
450 \\
3,000\end{array}$ & $\begin{array}{r}67,812 \\
7,200 \\
450 \\
3,000\end{array}$ & $\begin{array}{r}244,746 \\
12,000 \\
450 \\
3,000\end{array}$ \\
\hline 1,800 & 1,800 & 1,800 & 3,000 \\
\hline 49,319 & 82.81 & 0.217 & 303.18 \\
\hline 2,04 & $8 \times 3,005$ & 732,022 & $2,726,68$ \\
\hline ( & 0.37 & 0.31 & 0.19 \\
\hline
\end{tabular}


WORK BREAKDOWN STRUCTURE CASE $B$

SO\% Inoreseo in Staff Levila

Small $(x \$ 1000)$

1.0 Pro-Operation

1.1 Lend Aoquiatilon

1.2 Project Manegement

1.2.1 Labor

1.2.2 Suppliee

1.3 sho Selwetion / Charactertzation

1.3.1 sth Selection / Pre-characterization

1.3.2 Publlo Involvement

1.3.3 Charectertzation

1.3.4 Liligation

1.3.5 Easelino Monitoring

1.4 Lleanaing / NEPA

1.4 .1 Source Term

1.4.2 Analyais / Documentalion

1.3 Engineoring Design

1.6 Contingencies (for Hems 1.1 10 1.5)

Subtotal (Merns 1.1 10 1.6)

1.0.1 Interest and Principal on State Bonds (due 2018)

1.7 Facility Conatruction

1.7.1 Administration

1.7.2 Front End / Recerving

1.7.3 Waste Packeging

1.7.4 Disposal Units

1.7.5 Sthe Development

Subtotal Direct Costs (hems 1.7.1 to 1.7.5)

1.7. Contrector Overneed Fee (indirect Cost)

Subtotel Fecility Construction (them 1.7

1.8 Conatruction Munogement

1.9 Comtingenoy for Conatruction (for Hems 1.78 1.8)

Total Pre-Operational Costs

2.0 Operation

2.1 Annual Costs

2.1.1 Cell Conatruction

2.1.2 Admintulation (FTE)

2.1.3 Operations

2.1.4 Maintenance

2.1.5 Emvironmental Monitoring

2.1.6 Utilites / Materiale

Sublolal Annual Operational Coute (Hem 2.1)

2.1.7 Operators Proftt (5\% of annual conts)

Total Operational Coste over 30 years

3.0 Clowure

3.1 Cover Emplecemem

3.2 Demolition \& Decontamination

3.2.1 Administration

3.2.2 Fromt-End Receming

3.2.3 Waste Packoging

3.3 Administration (FTE)

3.4 Operations

3.5 Environmental Monitoring

3.0 Unilities / Materials

3.7 Contingenoy (for Mems 3.1 to 3.6)

3.8 Operators Proff (5\% $\times$ annual cost (items 3.1-3.6))

Total Closure Costs

4.0 Poes-Closure

4.1 Environmental Monitoring

4.2 Sito Remediation

4.3 Security

4.4 Maintenance

Total Post-Closure Costs

5.0 Community Benefles and Compenantion

5.1 Property Taxes (lotal over 40 veera)

3,000

4000

(2)

2,300
6.000

8,000

11,000

1.000

1,808

250

0,377

4,500

3,771

4.893

76,132

1,498

1.921

2,340

7.931

6.707

20.405

4,081

24.49

4.897

7,346

81,022

1,481

6.113
1,840

104

275

2,520

12.337

67

99

1,174

27,231

920

2.750

3.300

2.345

1,873

40,700

5,400

1,082

835

12,767

35,890

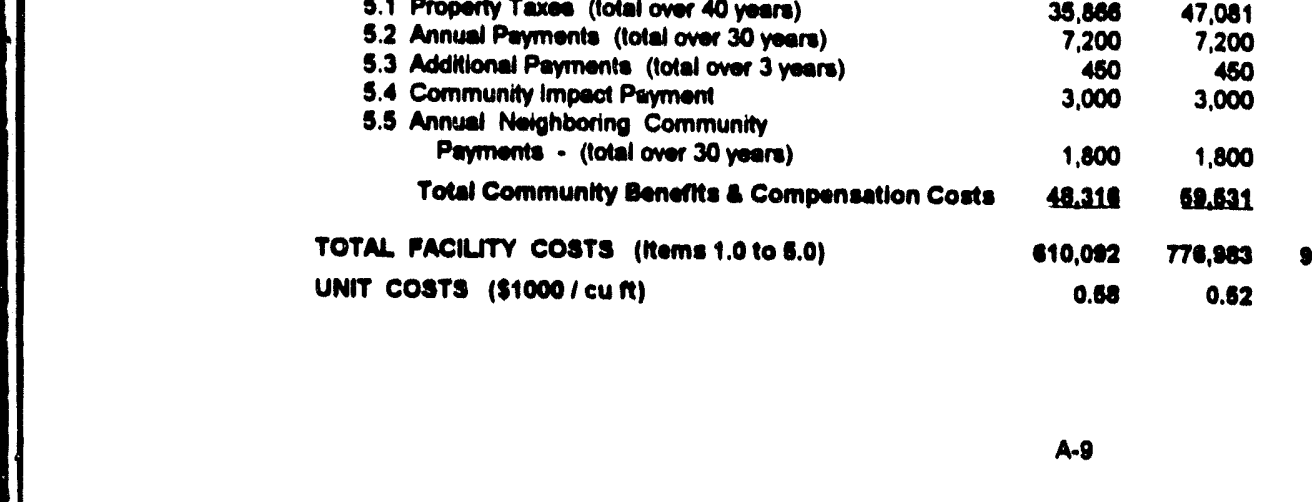

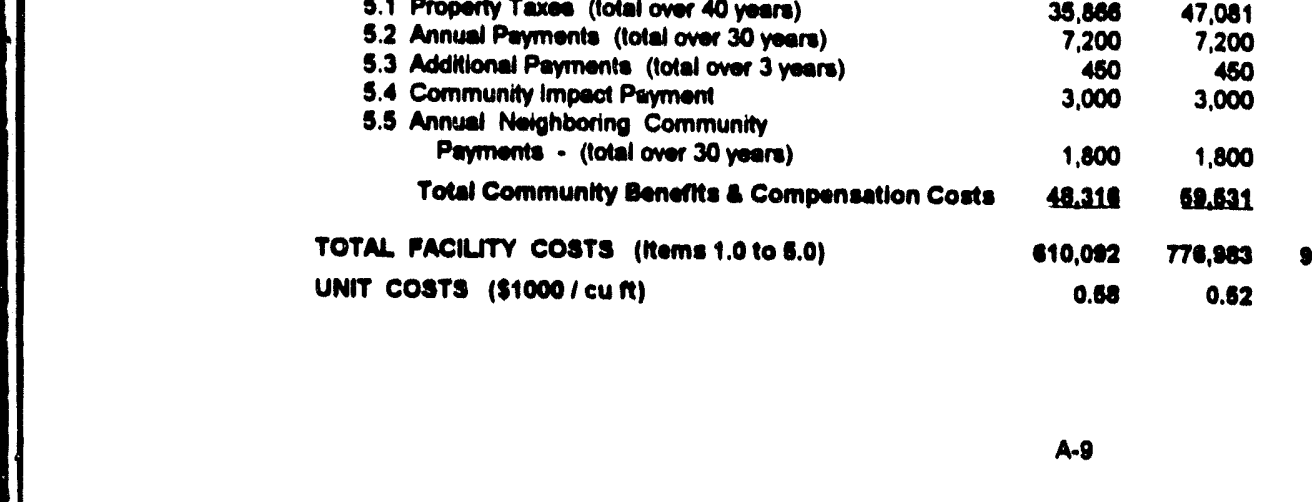

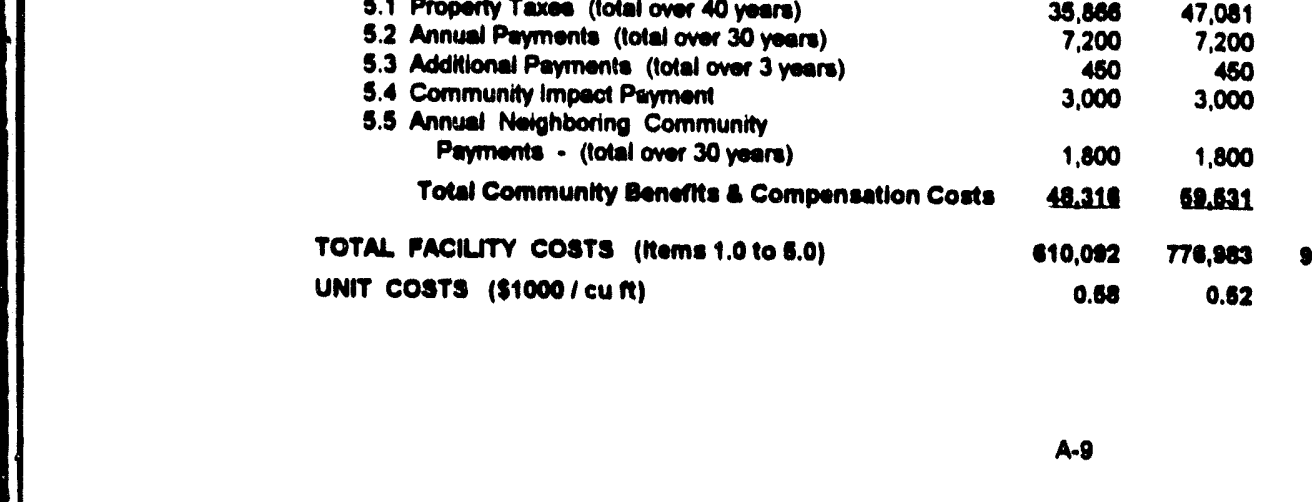

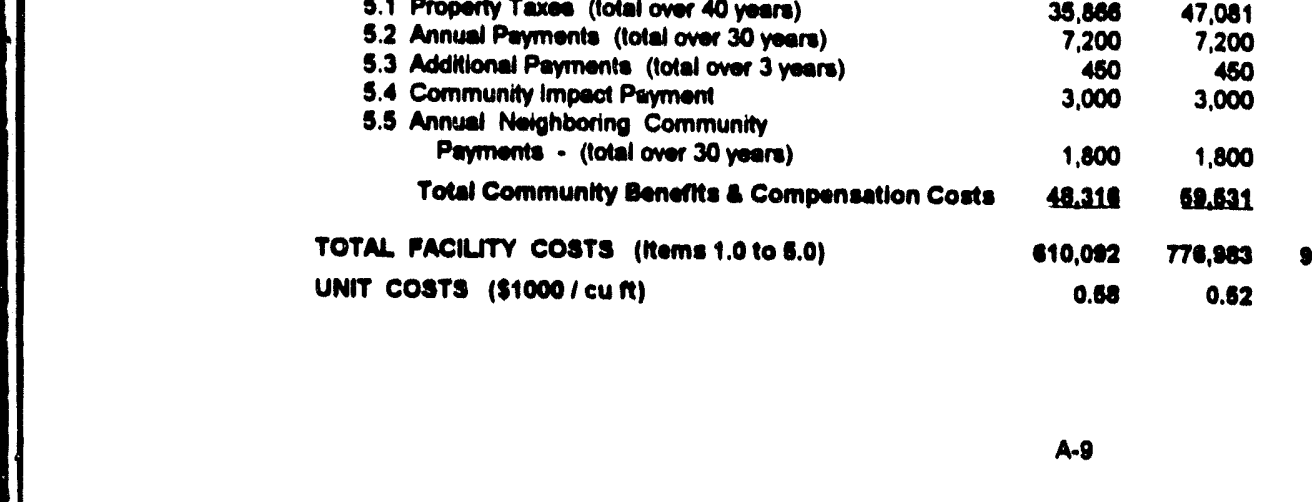

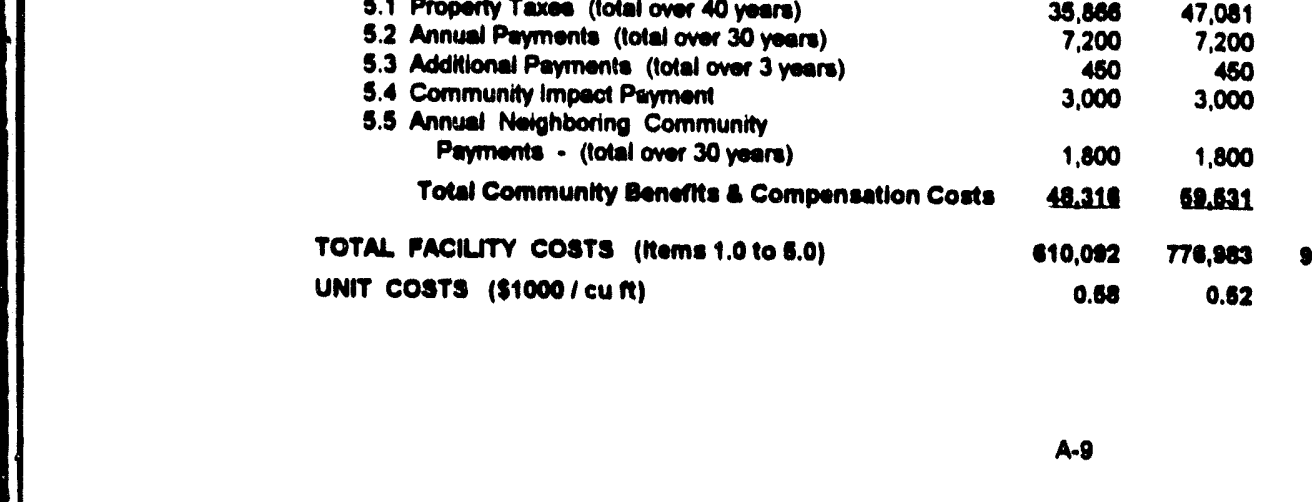

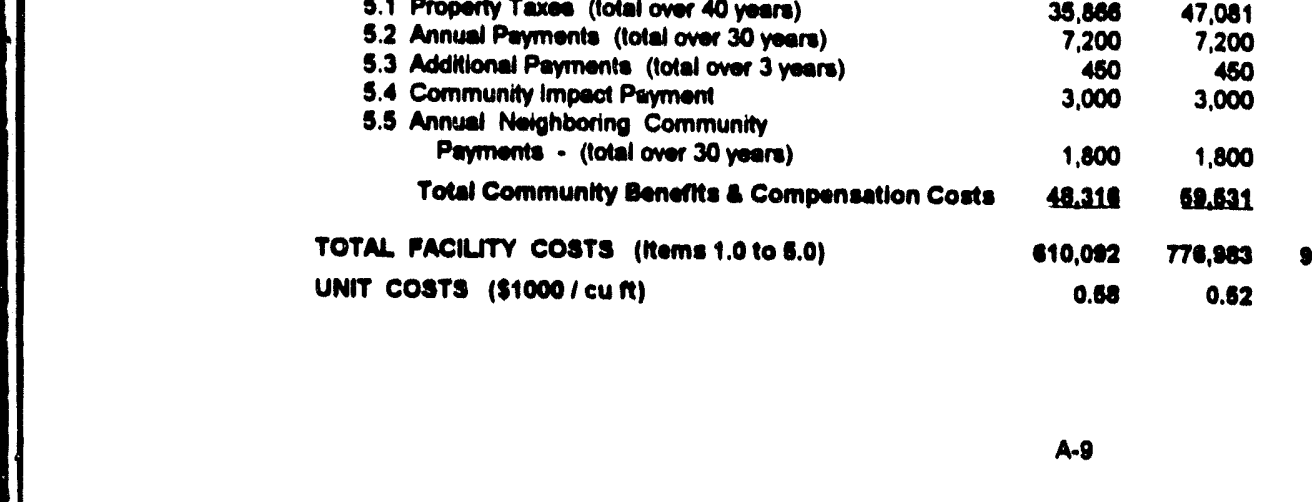

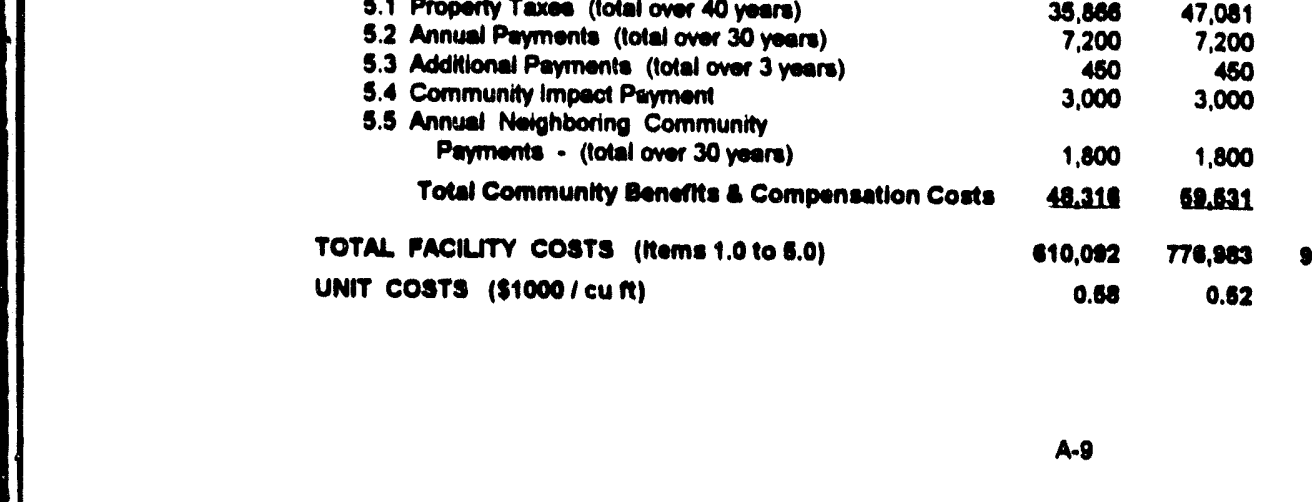

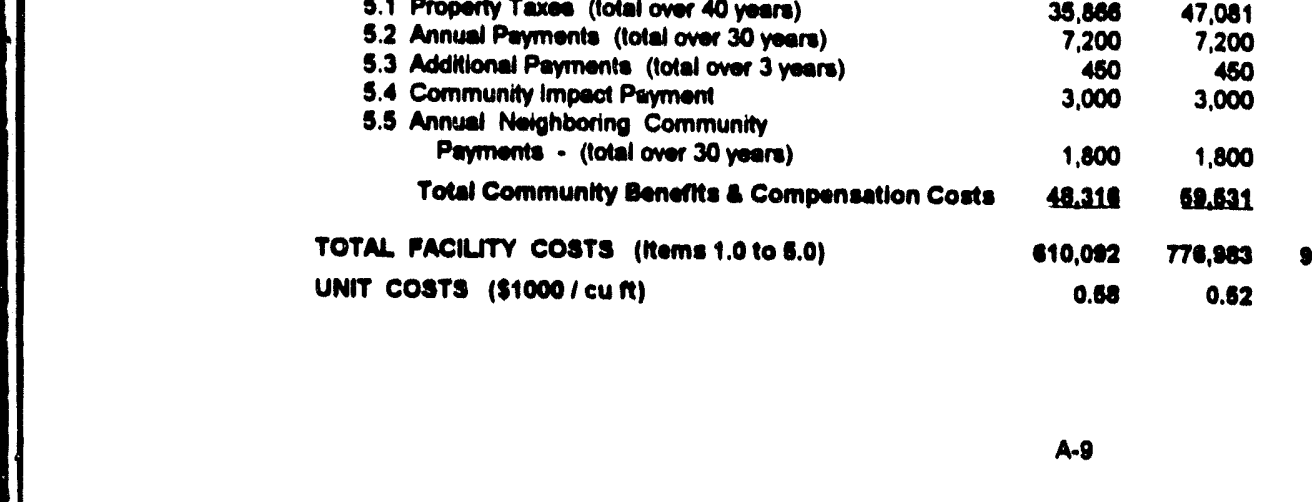

Madlum (x $\$ 1000)$

Larpe (x \$1000)

$X$-Large

3,000

3,393

4,200

4000

4000

4000

2,300

8,000

11,000

1,000

1,500

250

8,377

4,500

3,771

4.893

79,132

2,300

5,000

11,000

1,000

1,500

250

8,377

4,500

3,771

4 F. 28

76,790

1.732

2.377

3.062

7,931

7,457

22.559

4,512

27.07

5.414

8.121

80.49

2.221

2.493

3,062

7.931

8.388

24.078

4.815

28.891

5.778

8.687

8., 23

2,300

5,000

11,000

1,000

1,508

250
8,377

4,500

3.771

4. 093

$\pi, 141$

4.487

$\mathbf{5 . 5 4 4}$

6.555

19,640

14,698

50.921

10,184

e1.105

12.221

18,331

137,760

2,221

$7,6 \mathrm{ng}$

3,701

8,785

4,159

18.767

2,007
155

275

3,771

16.927

413

5,213

22.509

1.125

19.784

19.889

1,314

2,200

19,290

81.250

4,002

039,201

$709,043 \quad 2,889,359$

955

1,524

7.928

520

1,189

1,531

28,581

1,403

2,750

5,900

10.722

2.144

68,786

689

1,247

1.531

36,152

2,079

4,125

6,322

13.411

2,682

69,730

1,346

2,772

3,277

55,386

9,945

22,000

14,544

29.299

5,860

182,384

5,400

5,440

5,440
1,082

8,100

43.200

83.

8,160

4.23

43,520

8,656

19,13

6.676

12,767

102,082

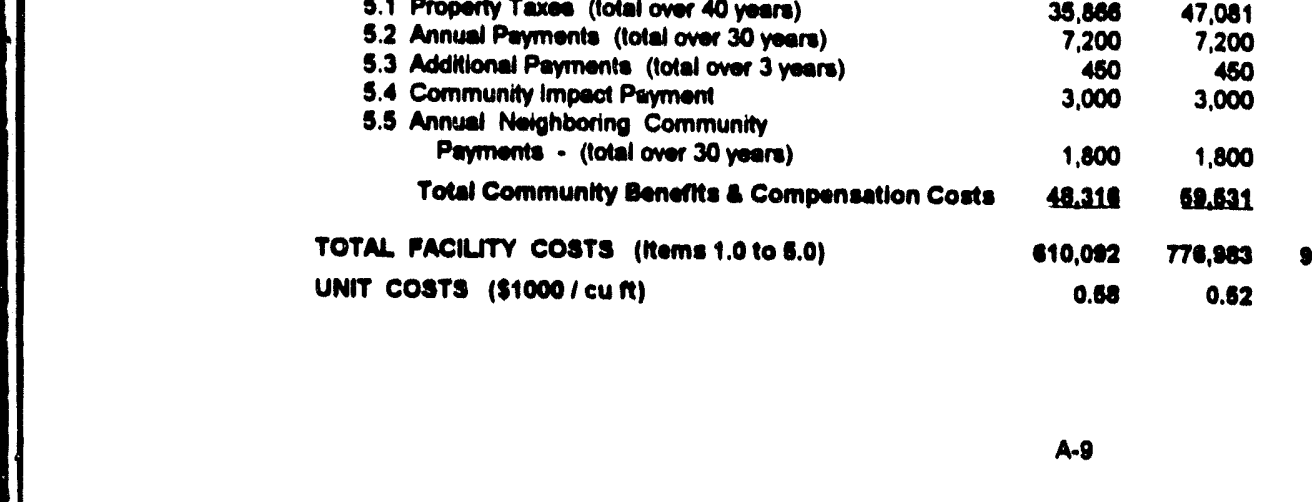

47,061

284,746

12,000

450

$3,000 \quad 3,000$

$1,800 \quad 3,000$

$80.297 \quad 303.19$

$997,309 \quad 3,286,789$

$0.42 \quad 0.23$ 
small

$(x \$ 1000)$

Modium

1.0 Preoparation

1.1 Land Acouteition

1.2 Project Managemem

1.2.1 Labor

1.2.2 Supplie

1.3 Ste Selection / Cherectertzation

1.3.1 sthe Sebetion / Pro-oharacterization

1.3.2 Publis Imotremem

1.3.3 Chancterization

1.3.4 Lilioation

1.3.8 Beselline Monitoring

1.4 Lleoneing / NEPA

1.4.1 Source Term

1.4.2 Analyis / Documentation

1.5 Engineering Design

1.8 Contingenoive (lor hems 1.1 to 1.5)

Subtotal (hems 1.1 to 1.0 )

1.8.1 Interest and Pincipal on state Donds (due 2018)

1.7 Facility Construetion

1.7.1 Administration

1.7.2 Front End / Recoiving

1.7.3 Waste Packoging

1.7.4 Disposel Units

1.7.5 Site Development

Sublotal Direot Coats (Hems 1.7.1 to 1.7.5)

1.7.8 Contrector Overheed Fee (indireet Cost)

Subtotel Facility Construction (item 1.7)

1.8 Construetion Mansogemem

1.9 Contingenoy for Construction (for heme $1.7 \& 1.8$ )

Total Pre-Operational Costs

2.0 Operation

2.1 Annual Coats

2.1.1 Cell Construction

2.1.2 Administration (FTE)

2.1.3 Operations

2.1.4 Maintenance

2.1.5 Emvionmental Monitoring

2.1.6 Uilitien / Materiab

Sublotel Annuel Operational Coats (Hem 2.1)

2.1.7 Operatore Proft (5\% annual coste)

Total Operational Costs over 30 years

3.0 Closure

3.1 Cover Emplecement

3.2 Demolition \& Decontamination

3.2.1 Administration

3.2.2 Front-End Recerving

3.2.3 Waste Packaging

3.3 Adminialration (FTE)

3.4 Operations

3.5 Environmental Monitoring

3.6 Unilities / Materiala

3.7 Contingenoy (lor Hems 3.1 to 3.6 )

3.8 Operator Prom (5\% $\times$ annual costs (items 3.1-3.6))

Total Closure Costa

4.0 Post-Closure

4.1 Environmental Monitoring

4.2 Site Remediation

4.3 Secunty

4.4 Maintenanos

Total Post-Closure Costs

5.0 Communit, Eenefite and Compeneation

\section{3,000}

4,000

187

2,300

000

11,000

1,000

1,508

250

8,377

4,500

3,771

4.993

78,132

1.498

1.921

2.348

7.931

6.707

20.405

4.081

24.489

4,807

7,349

81, 82
3,000

4,000

187

2,300

5,000

11,000

1,000

1,608

250
8,377

4,500

3.771

4.892

76,132

1.732

2.377

3,062

7,931

7,457

22.559

4.512

27071

5,414

8,121

80.45

1,481

2.221

10,269

2.807

1.840

275

2,900

14.76 .

739

49,77

155

275
4.317

20.039

1.002

a1,24

671

995

449

520

1.189

1.531

38,108

1.403

2.750

7.159

13,404

2,681

a,os

5,400

5,440

1,082

839

12,767

5,400

12,767

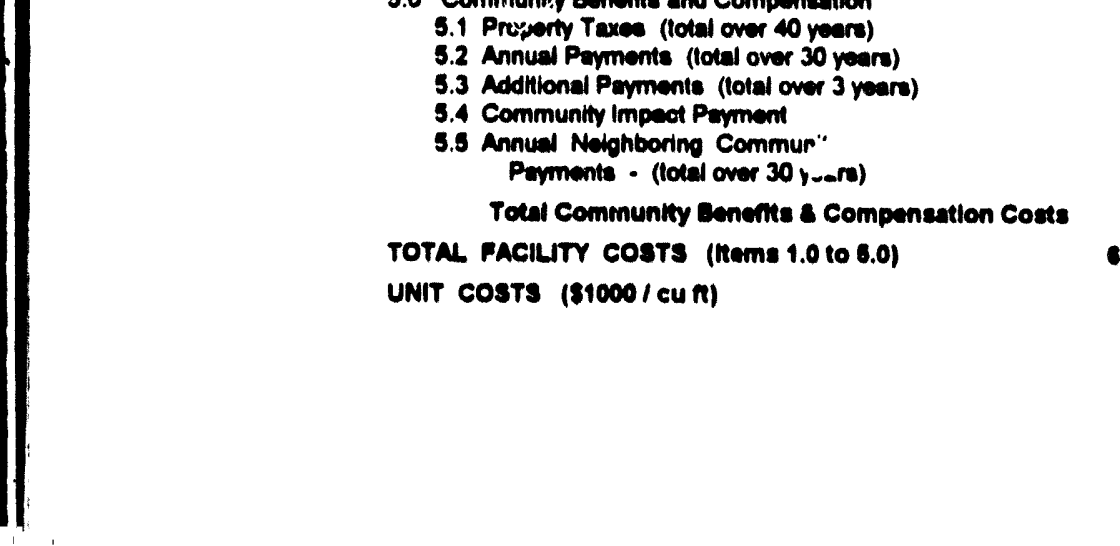

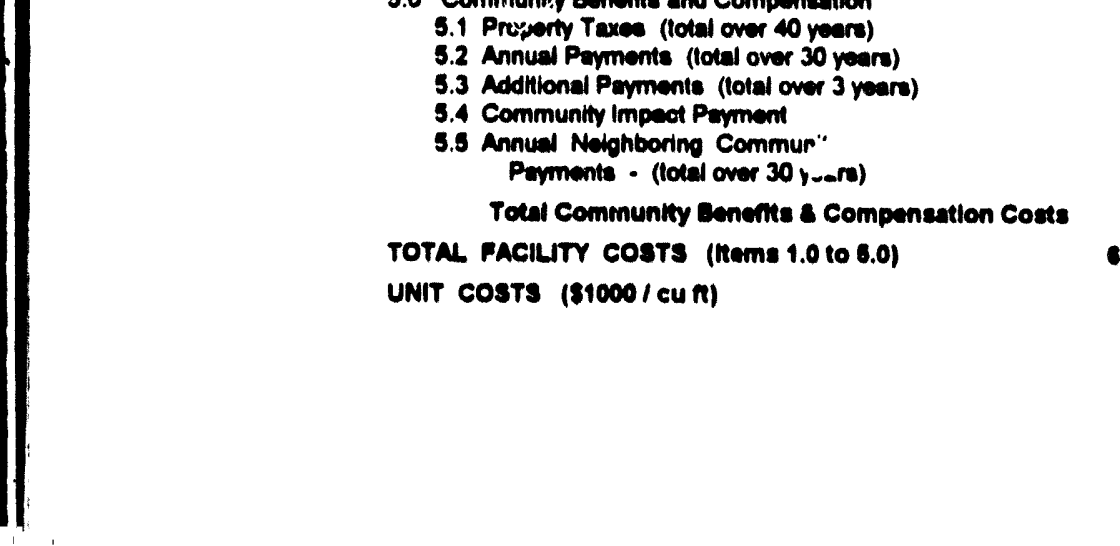

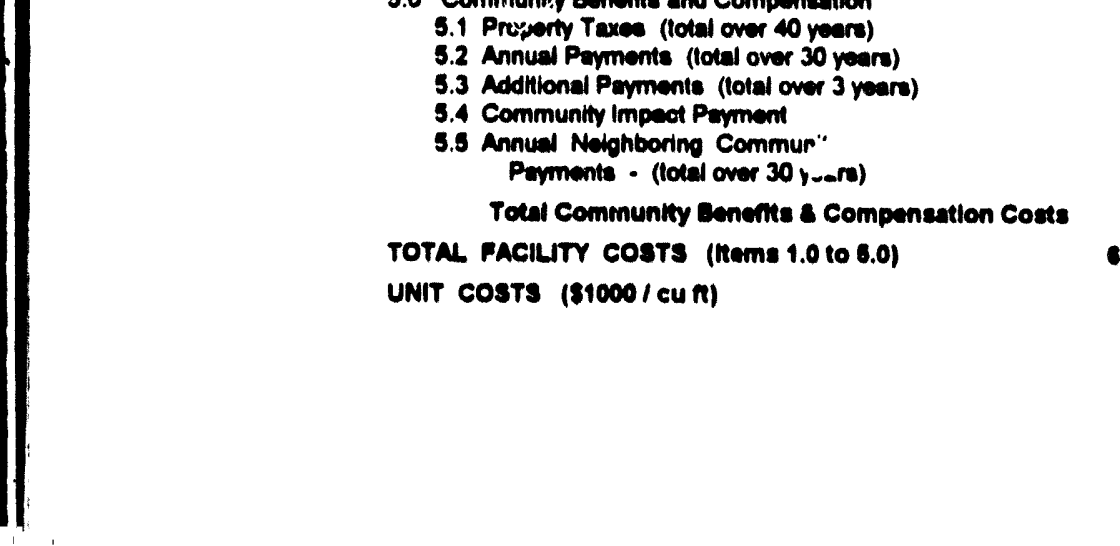

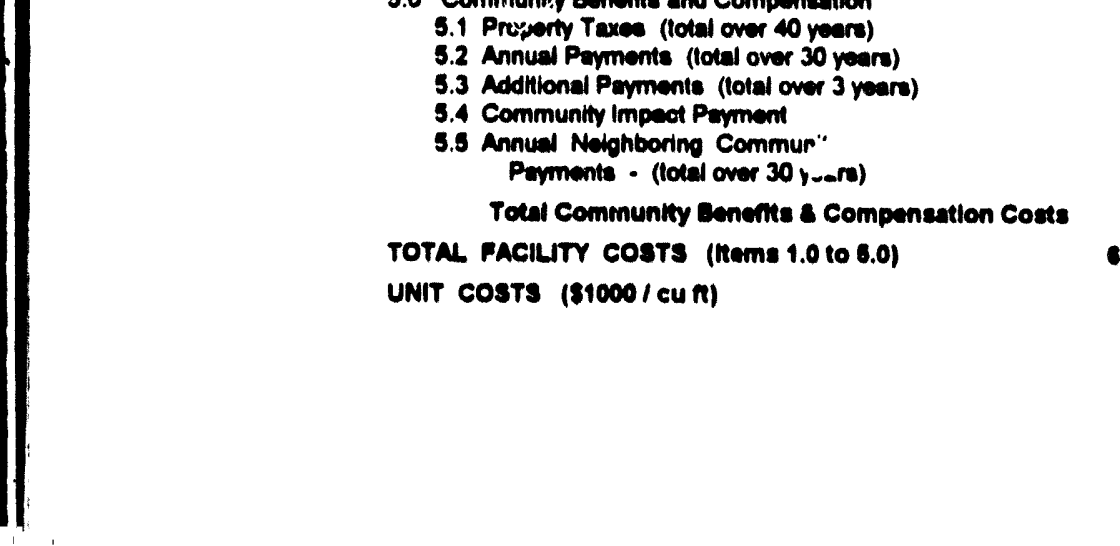

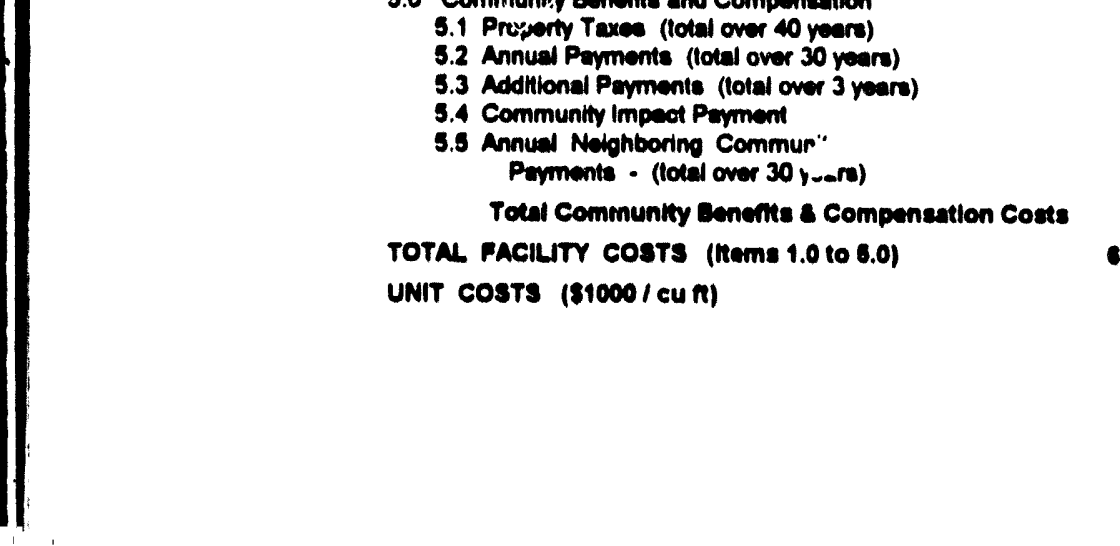

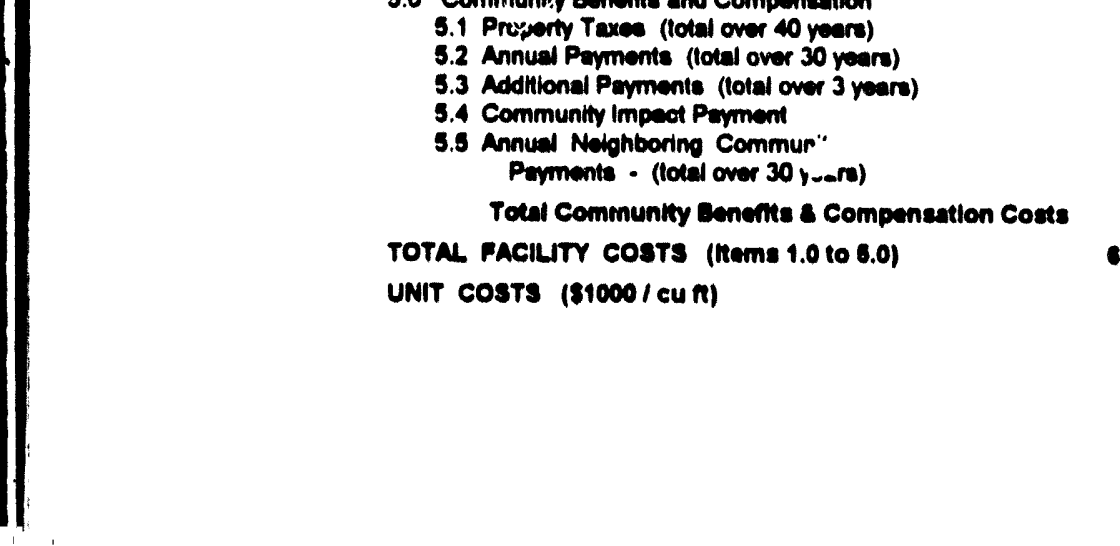

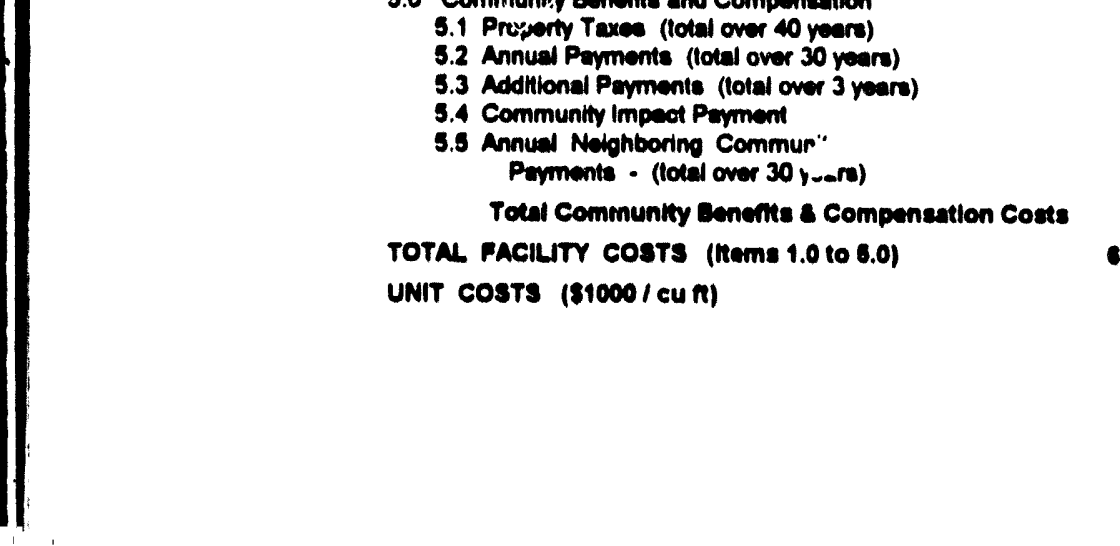

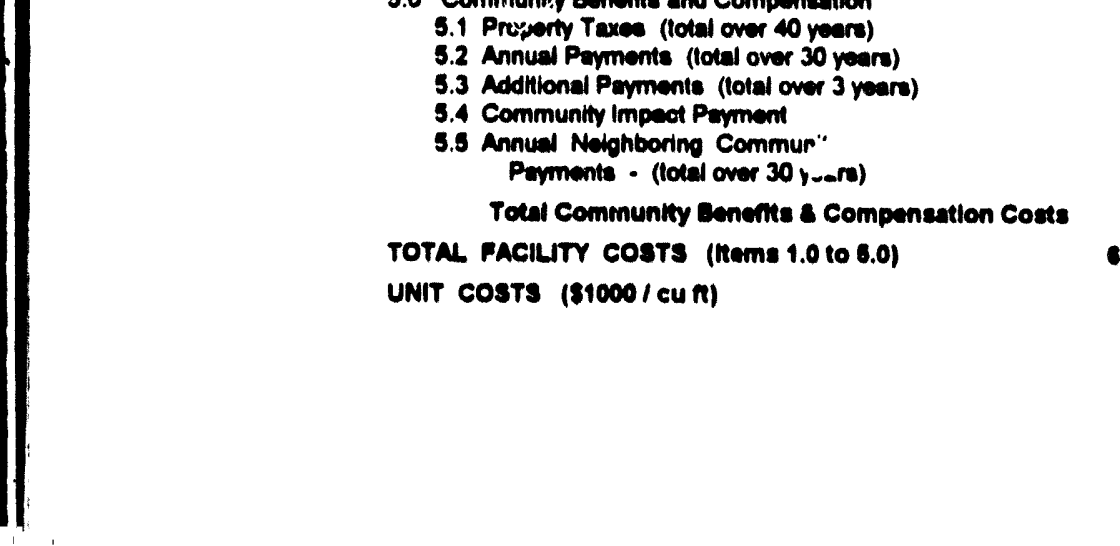

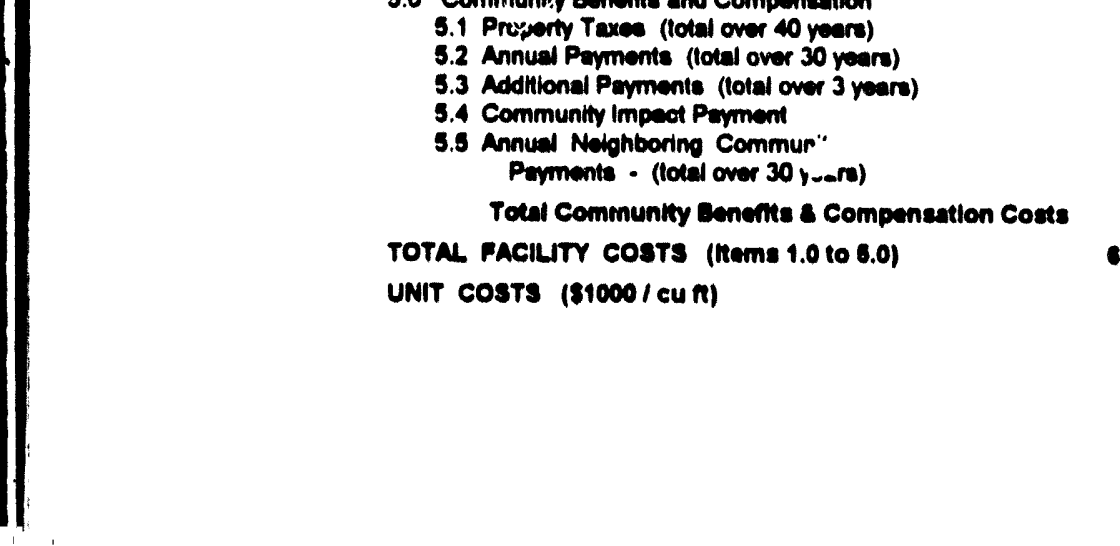

(x \$1000)

Lareo

(x $\$ 1000)$

$x$-Large

$(x \$ 1000)$

3,393

4,200

4,000

4,000

187

2,300

8,000

11,000

1,000

1,508

250

4,500

3.771

48.28

76,700

2,300

5,000

11,000

1,000

1,808

250

8,377

4,500

3,771

4.093

2.221

2,493

3.002

7,931

8,360

24.070

4.815

2.. 891

$\$, 778$

8.687

8,023

7,141

4.487

5.544

6.555

19.640

14.690

50.921

10,184

61.105

12,221

18,331

137,780

3,701

11,606

4,159

259

413

5.951

28.169

1,308

824,316

18.787

26,379

19.889

1,314

2,200

20,709

82.257

4,403

$2,811,600$

1,524

7.926

688

1,247

1.531

$\mathbf{4 8 , 2 0 2}$

2,070

4.125

7,632

16.752

3,350

87, 100

1.346

2.772

3.277

73.848

9.945

22,000

17,457

34.643

6,929

180,142

8.100

8,160

1,623

1.252

19,136

43.200

$\mathbf{4 3 , 5 2 0}$

8,650

6.670

102,052

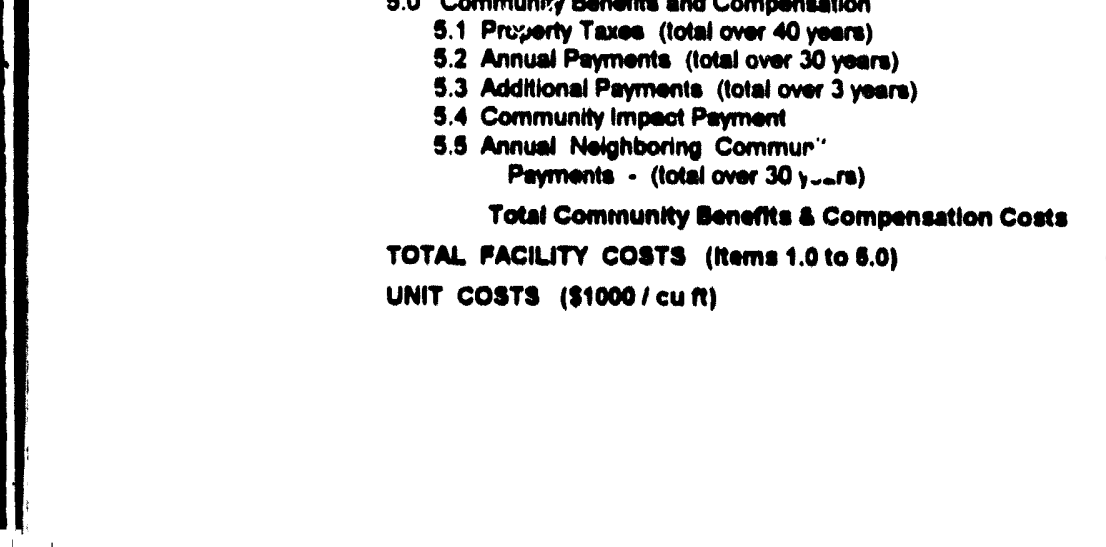

\begin{tabular}{|c|c|c|}
\hline $\begin{array}{r}47,081 \\
7,200 \\
480 \\
3,000\end{array}$ & $\begin{array}{r}67,812 \\
7,200 \\
460 \\
3,000\end{array}$ & $\begin{array}{r}284,744 \\
12,000 \\
450 \\
3,000\end{array}$ \\
\hline 1,800 & 1,800 & 3,000 \\
\hline 8.9.91 & 0229 & 39.18 \\
\hline 0,97 & $1,129,840$ & $3,696,7 \mathrm{ve}$ \\
\hline 0.6 & 0.47 & 0.28 \\
\hline
\end{tabular}


WORK BREACDOWN stRUCTURE CASE 0 Initid stedo Coen $\$ 22 \mathrm{M}$

1.0 Pro-Operetion

Smell Madlum Large x-Lorge

1.1 Lend Aoquivition

1.2 Project Munegemem

1.2.1 Labor

1.2.2 Suppitiee

1.3 sho Seleotion / Cherectertzation

1.3.1 She Selection / Pre-charecteriation

1.3.2 Publlo involvement

1.3.3 Chanceterization

1.3.4 Liligation

1.3.8 Beaclino Monitoring

1.4 Llowaing I NEPA

1.4.1 Souroe Term

1.4.2 Analyala / Documentation

1.5 Engineering Deaign

1.6 Contingencies (lor Homs 1.1 10 1.5)

Sublotal (thome $1.1101 .0^{\circ} 22.000^{\circ} 22.000^{\circ} 22000^{\circ} 22.000$

1.6.1 Imereat and Principel on State Bonda (due 2018)

30,81

$30,018 \quad 36,818$

38,818

1.7 Facilly Conatruation

1.7.1 Administration

1.7.2 Front End / Recowing

1.7.3 Wrato Peckaging

1.7.4 Disposel Unite

1.7.5 Sino Development

Sublotel Direot Coed (Mems 1.7.1 to 1.7.)

1.7.6 Contruetor Overtead Foe (Indirect Coed)

Subtoted facilly conalnuction (iem 1.n)

1.8 Conetruction Manecement

1.8 Contingency foe Conetruction (for Meme 1.7 \& 1.8)

Tocal Pre-Operational Coste

1,499

1,921

2,340

7,931

6.707

20.400

10.11

24,480

4,807

7,340

60,720

2.0 Operation

2.1 Annual Coats

2.1.1 Cell Conatruction

2.1.2 Adminiatration (FTE)

2.1.3 Operetione

2.1.4 Muimteriance

2.1.5 Emironmental Moninoring

2.1.8 Uillitice / Meicenats

Subtotel Annuel Oparational Coets (Mem 2.1)

2.1.7 Operetore Profill (5\% of annual coste)

Total Operational Costs over 30 years

3.0 Clocure

3.1 Cover Emplecement

3.2 Demolition \& Decontamination

3.2 .1 Adminiatration

3.2.2 Front-End Rocewing

3.2.3 Walto Packeging

3.3 Adminialration (FTE)

3.4 Operatiom

3.5 Environmental Monitoring

3.6 Unilition / Mutenala

3.7 Contingeney (for Heme 3.1 10 3.6)

3.8 Oparator' Proft (5\% $x$ annual cost (items 3.1-3.6))

Total Closure Costs

1,491

4,151

1.840

104

275

2.130

299

400

314,618

1,732

2.377

3,002

7,931

2467

22,599

1.512

27,071

5.414

8,121

02,600

2.221

2,493

3,062

7.931

2369

24,076

1815

28,891

5,778

8,687

06,337

4,487

5,544

6.555

19.840

14.69

50,921

10.18

61.105

12,221

18,331

113,067

2,221

5,20

2.807

155

275

3.224

13.890

608

437,037

3,701

5,00

4.158

258

413

4.475

12001

860

650,620

18.787

13,340

19,889

1,314

2,200

18,044

23.554

3,678

671

49

955

1.524

$2,316,947$

99

1.174

18.154

920

2.750

2.600

6.972

1.384

38,903

520

1.189

1,531

19,054

1,403

2,750

3,952

2839

1,560

40,760

606

7,926

1,247

1.531

24,101

2,079

1,125

5,008

10.070

2.014

62,368

1,340

2.772

3,277

36,924

9.945

22,000

11,004

23.798

4.780

123,762

4.0 Poat-Closure

4.1 Environmontal Monitoring

4.2 SHo Remediation

4.3 Security

1.4 Muintonance

Total Post-Closure Coste

5,400

5.440

1,002

5,400

5,440

1,082

8,100

8.160

1.623

1252

43,200

43,520

8,650

6.676

12.767

19,136

102,032

5.0 Community Benemte and Compeneation

5.1 Property Taves (lotal over 40 veers)

5.2 Annual Ponments (lotal over 30 veares)

5.3 Addilionel Parmenta (lotel over 3 yeare)

5.4 Community impect Payment

5.5 Ann':al Nalohboring Community ments - (lotal over 30 years)

Total Community Eenemts 4 Compensention Costs

TOTAL PACILIT COSTS (kems 1.0 to 6.0)

UNIT COSTS (\$1000/ cun)
12,767

34.813

7,200

460

3,000

1,800

17.21:

404,075

0.46
40,028

7,200

460

3,000

60.022

7,200

450

3,000

283,271

12,000

480

3,000

1,800

0.47

028,667

1,800

3,000

21072 301.729

820,264 2,972,440

0.42

0.20

0.21 
1.0 Freoperation

1.1 Lnd Acquimiten

1.2 Projud Manceomen

1.2.1 Labor

1.2 .2 suppline

1.3 8he seloction / Chardotertation

1.3.1 ans atection / Preshernotertation

1.3.2 Publin Imotrument

1.3.3 Chareatertsetion

1.3.4 uniouton

1.3.5 Eeseline Monthoring

1.4 Lewaing I NEPA

1.4.1 Soure Tem

1.4.2 Anatyala / Documentation

1.5 Enoinuring Dwaign

1.0 Contingencies (lor Heme 1.1 10 1.5)

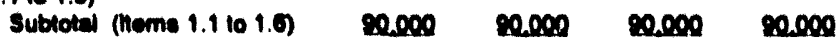

1.4.1 Interest and Princlpal on stute Donds (due 2018)

10,02

100,023

10.023

160.023

1.7 Fecility Construction

1.7.1 Administration

1.7.2 Prom End / Recerving

1.7.3 Waste Packeging

1.7.4 Disposal Units

1.7.5 she Dewelopment Subtotel Direct Conts (hem 1.7.1 to 1.7.9)

1.7. Contractor Overtiend Fee (indireal Cow) subtotel Froility Conatruction (liem 1.n)

1.8 Construetion Munecement

1.9 Contingenoy for Construction (for Reme 1.7 1.8)

Totel Pro-Operationd costs
1.921

2.348

7.931

$\mathbf{8 . 7 0 7}$

$20.4 \%$

4.091

24.1...

4.897

7,340

120,720

$$
1.495
$$

1.732

2.377

3,002

7,931

7.467

22.549

4,512

22071

3,414

8,121

130,000
2.221

2,493

3,002

7.931

8,380

24070

4.815

2. .891

5.778

8,607

139,337
4.487

$\mathbf{5 . 5 4 4}$

6,555

19.640

14,68

50.921

10.184

a1.105

12,221

18.331

181,057

2.0 Operation

2.1 Annual Conts

2.1.1 Cell Construction

2.1.2 Adminitiotion (PTE)

2.1.3 Opertions

2.1.4 Mintenience

2.1.5 Envionmented Monitoring

2.1.6 Uallinies / Meteriala

Subtoted Amual Operational Cout (Mem 2.1)

2.1.7 Operevare Prom (5\% of annud costs)

Total Operational conte over 30 years

1.481

4,151

180

2.221

5,205

2,807

158

275

3,22

13.299

2,13

2904

40

6

314,018

437,837

3,701

$\mathbf{5 , 9 0 4}$

4,159

258

413

4,479

19.91
800

00,82

18.767

13,340

19,889

1.314

2.200

18,044

23.554

3.078

3.0 Clomure

3.1 Corer Emplecement

3.2 Demolition \& Decontamination

3.2.1 Adminietration

3.2.2 Front-End Receiving

3.2.3 Waste Packaging

3.3 Adminietration (FTE)

3.4 Operations

3.5 Environmentel Montoring

3.8 Vilinies / Materiats

3.7 Contingenoy (for hems 3.1 to 3.6 )

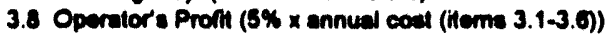

Total Closure Coste

87

95

1.524

2,310.947

44

981

1,174

18,154

920

2.750

2,009

6.920

1,384

38,95

520

1.189

1,531

19,054

1,403

2,750

3,952

7.439

1,588

40,700

698

1,247

1,531

24,101

2,079

4.125

5,008

10.070

2,014

82,2ns

7.926

1,340

2.772

3,277
39.924

$\mathbf{3 6 . 9 2 4}$

9,845

22,000

11,004

23.798

4.760

123,762

4.0 Poet-Closure

4.1 Environmental Moninoring

4.2 She Remediation

4.3 sceurny

4.4 Maimenence

Total Post-Closure Costs

5,400

5.440

1,092

5,400

5,40

8,100
8,160

43.200

1,082

1,622

1.252

$\mathbf{4 3 , 5 2 0}$

8,656

6.676

12,757

12,757

19,130

102,062

5.0 Community Benctite and Compensation

5.1 Property Taxes (lotel over 40 years)

5.2 Annual Payments (lotal over 30 years)

5.3 Addhiond Parmente (lotel over 3 veres)

5.4 Community imper Perment

5.5 Annud Neightoring Community

Purments - (lotil ower 30 vears)

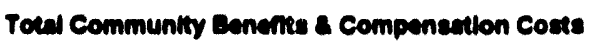

37,972

7,200

460

3,000

49,187

7,200

460

3,000

70.192

7.200

480

287.694

12,000

$3,000 \quad 3,000$

1,800

1,800

1,000

3,000

a.4\%

a1: 9

peng 3anc4

091,042

743,020

Ma,029 $3,001,17$

0.97

0.60

0.39

0.22 
1.0 Precopertion

1.1 Lend Aoquiation

1.2 Project Managenem

1.2.1 Lebor

1.2.2 Suppline

1.3 sine selwetion / Chersetertzation

1.3.1 sho seceotion / Pre-charecterization

1.3.2 Puble involvemeont

1.3.3 Chersotertzation

1.3.4 Litiontion

1.3.6 Eceelino Moniloring

1.4 Llowaing I NEPA

1.4.1 Source Term

1.4 .2 Anatris / Documentotion

1.5 Engineering Design

1.6 Contingeneves (lor neme 1.1 to 1.5)

Subtotel (neme 1.1 10 1.6)

Smell Mnolium

$(x \$ 1000$

Laros

$(x \$ 1000)$

$x$-Lares

1,800

1,800

1.007

2,100

4,000

4,000

$\quad 4,000 \quad 4,000$

4,000
187

4,000

187

187

2,300

8,000

11,000

2,300

5,000

2,300

8,000

11,000

11,000

1,000

2,300

1,508

$\$ .000$

11,000

260

.377

4,500

250

8,377

4,500

250

0.377

4,500

3.771

$43.5 \%$

1,000

1,500

1.6.1 Interest and Principal on state Bonds (due 2018)

72,62

72,020

12.962

250

8,377
4,500

3.771

43.993

1.7 Facility Consunction

1.7.1 Adminiatration

1.7.2 Front End / Recoming

1.498

1,732

2.221

1.73 Waste Packaging

1.7.4 Disposel Units

1.7.5 Sine Devolopment

Sublotel Direet Couts (heme 1.7 .1 10 1.7.5) 00.5

2,340
7,931

7.931
8.707

2.377

2,493

3,002

7.931

7.457

7.931

8,368

11.280

12.03.

2,040

Subtotal Faciliny Conatruction (Item $1 . n$

2,250

2,408

13.53.

13.448

2,449

2,707

1.9 Contingency for Construction (for Hems 1.78 1.8)

3.673

4.061

2.889

4.334

03,608

06.280

4.487

3.544

6,555

19.640

(4.080

5.092

30.582

0.110

9.168

89,822

2.0 Operation

2.1 Annual Coete

2.1.1 Cell Conatruction

2.1.2 Adminiatration (FTE)

2.1.3 Operetions

2.14 Muimenence

2.1.5 Environmental Monitoring

2.1.6 Uilinies / Meteriale

Sublotel Annual Operational Coeds (fiem 2.1)

2.1.7 Operators Profl (5\% of annual couta)

Total Operational Coats over 30 yoars

$741 \quad 1.111$

1.111
5,200

1.851

5.894

9.364

2.807

4.150

13,340

1.84

52
275

79
275

3224

130

19,809

$413 \quad 657$

2.200

$2.193 \quad 12.703$

18.04

635

$851 \quad 3,178$

209,893

400,132

\$35, 162 2,000,703

3.0 Closure

3.1 Cover Empleciememt

3.2 Demolition a Decontamination

3.2.1 Adminietration

3.2.2 Front-End Recemno

3.2.3 Weale Packeging

3.3 Adminiatration (FTE)

3.4 Operations

3.5 Emvironmemal h.onioring

3.6 Uniltion / Maleriale

3.7 Contingenoy (lor Hems 3.1 lo 3.0

3.8 Operatora Proflt (5\% $x$ annual coed (itome 3.1-3.8))

Total Closure Coste

330

49

991

1.17

18.154

920

2.750

3.962

2174

1,436

37,306

478

520

1.189

1.531

19,054

1,403

2.750

3,952

2.719

1,544

$\mathbf{4 0 . 1 4 0}$

762

680

1,247

1.531

24.101

2.079

4.125

3,952

9.616

1,923

60,002

5.400

5,40

1.082

835

Total Post-Closure Costs

12,767

5.400

5,440

1.082

835

12,767

8.100

8.160

1.623

1.252

19,136

3.648

1,340

2.772

3.277

36,924

9,945

22,000

3,952

20.969

4.193

105,023

17,933

7,200

23,541

7,200

460

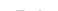

$\begin{array}{r}4.000 \\ \hline\end{array}$

43.200

43.520

8.656

6.676

102.062

3,000

1,800

1,800

1,800

142.373

12,000

450

30.39

461,023

38.921

601,244

40.302160 .029

$748,221 \quad 2,492,060$

0.31

0.18

0.30

UNIT costs (\$1000/cun) 
WORK BREAKDOWN STRUCTURE CASE $O$ so\% inerease in Cupled Cost

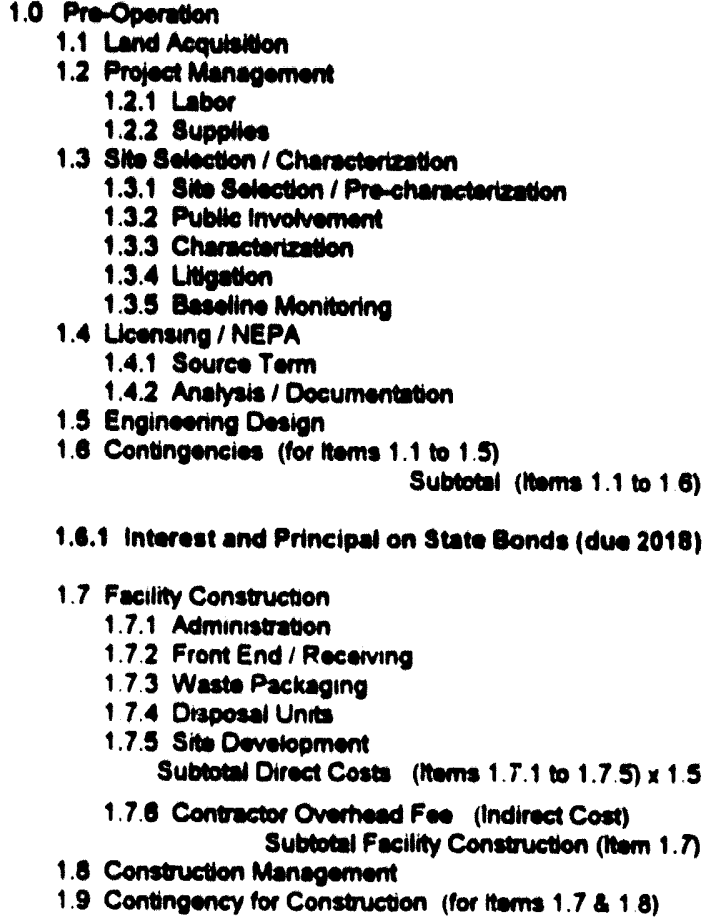

\begin{tabular}{|c|c|c|c|}
\hline $\begin{array}{r}\text { Small } \\
(\times \$ 1000)\end{array}$ & $\begin{array}{l}\text { Medium } \\
(x \$ 1000)\end{array}$ & $\begin{array}{r}\text { Large } \\
(x \$ 1000)\end{array}$ & $\begin{array}{l}x \text {-Large } \\
(x \$ 1000)\end{array}$ \\
\hline 4,500 & 4,500 & 5,000 & 0,300 \\
\hline $\begin{array}{r}4,000 \\
187\end{array}$ & $\begin{array}{r}4,000 \\
187\end{array}$ & $\begin{array}{r}4,000 \\
187\end{array}$ & $\begin{array}{r}4,000 \\
187\end{array}$ \\
\hline $\begin{array}{r}2,300 \\
5,000 \\
11,000 \\
1,000 \\
1,500\end{array}$ & $\begin{array}{r}2,300 \\
5,000 \\
11,000 \\
1,000 \\
1,500\end{array}$ & $\begin{array}{r}2,300 \\
5,000 \\
11,000 \\
1,000 \\
1,500\end{array}$ & $\begin{array}{r}2,300 \\
5,000 \\
11,000 \\
1,000 \\
1,500\end{array}$ \\
\hline $\begin{array}{r}250 \\
0,377 \\
4,500 \\
3,771 \\
46,393\end{array}$ & $\begin{array}{r}250 \\
8.377 \\
1.500 \\
3.771 \\
46.393\end{array}$ & $\begin{array}{r}250 \\
8,377 \\
4,500 \\
3,771 \\
48.983\end{array}$ & $\begin{array}{r}250 \\
8.377 \\
4.500 \\
3.771 \\
48.193\end{array}$ \\
\hline 77,043 & 77,643 & 78,030 & 80,686 \\
\hline $\begin{array}{r}1.498 \\
1.921 \\
2.348 \\
7.931 \\
0.707 \\
30.607\end{array}$ & $\begin{array}{r}1.732 \\
2.377 \\
3.062 \\
7.931 \\
7.467 \\
33.839\end{array}$ & $\begin{array}{r}2.221 \\
2.493 \\
3.062 \\
7.931 \\
8.368 \\
36.114\end{array}$ & $\begin{array}{r}4,487 \\
5,544 \\
6,555 \\
19.640 \\
14.698 \\
78.381\end{array}$ \\
\hline $\begin{array}{r}0.121 \\
38.729 \\
7,346 \\
11.019\end{array}$ & $\begin{array}{r}6.700 \\
40.800 \\
8.121 \\
12,182\end{array}$ & $\begin{array}{r}7.223 \\
43.337 \\
8.667 \\
13.001\end{array}$ & $\begin{array}{l}15.276 \\
91.657 \\
18,331 \\
27.497\end{array}$ \\
\hline 101,486 & 107,302 & 111,987 & 186,679 \\
\hline
\end{tabular}

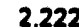

4.15

1.840

158

275

2.136

10.77.

539

339,810
3,332

5.208

2,807

233

275

$\frac{15079}{754}$

$\mathbf{4 4 , 9 9 1}$

1,007

1.433

449

981

1,174

18.154

920

2,750

2.609

200:

1.401

38,431

520

1,189

1.531

19.054

1.403

2.750

3,952

7.958

1.592

41,381

5.400

5,440

1.082

835

12,767

53,798

7,200

450

3,000

1,800

02.24

887,682

0.69
5.400

5.440

1.082

835

12,767

70.622

7,200

460
3,000

3,000

1,800

93.072

760,762

0.60

\begin{tabular}{rr}
5,552 & 28,151 \\
5,994 & 13,340 \\
4,159 & 19,889 \\
389 & 1.971 \\
413 & 2.200 \\
4,475 & 18.044 \\
20.891 & 83.598 \\
1,049 & 4,180 \\
\hline 60,904 & $2,033,247$
\end{tabular}

2,288

11.889

1.346

2.772

3.277

38.924

9.945

22.000

11,004

24.789

4.958

128,904

63,389

8,100

8,160

1,623

1252

19,136

43.200

43,520

8,656

6.676

102,062

101,719

7.200

450
3,000

427,118

12.000

450
3,000

$1,800 \quad 3,000$

14.169

4.8.58

$991,198 \quad 3,627,912$

0.41

0.26 
WORK BAEAKOOWN STRUCTURE CASE H 100\% inerease in Cespital Costs

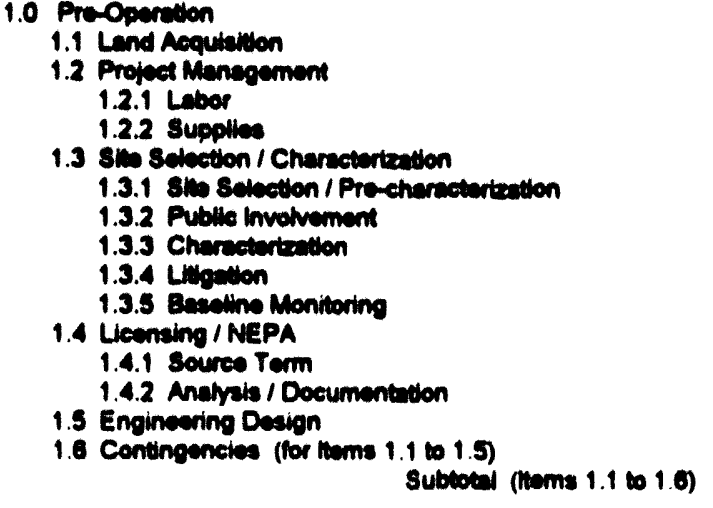

1.8.1 Interest and Principel on State Eonds (due 2018)

\begin{tabular}{|c|c|c|c|}
\hline $\begin{array}{r}\text { small } \\
\text { (x s1000) }\end{array}$ & $\begin{array}{l}\text { Medlum } \\
(x \$ 1000)\end{array}$ & $\begin{array}{r}\text { Large } \\
(x \$ 1000)\end{array}$ & $\begin{array}{r}X \text {-Large } \\
(x \$ 1000)\end{array}$ \\
\hline 0.000 & 0,000 & 8,780 & 8,400 \\
\hline $\begin{array}{r}4,000 \\
187\end{array}$ & $\begin{array}{r}4,000 \\
187\end{array}$ & $\begin{array}{r}4.000 \\
187\end{array}$ & $\begin{array}{r}4,000 \\
187\end{array}$ \\
\hline $\begin{array}{r}2,300 \\
5,000 \\
11,000 \\
1,000 \\
1,500\end{array}$ & $\begin{array}{r}2,300 \\
5,000 \\
11,000 \\
1,000 \\
1,500\end{array}$ & $\begin{array}{r}2,300 \\
5,000 \\
11,000 \\
1,000 \\
1,500\end{array}$ & $\begin{array}{r}2,300 \\
5,000 \\
11,000 \\
1,000 \\
1,508\end{array}$ \\
\hline $\begin{array}{r}260 \\
8,377 \\
4,500 \\
3.771 \\
47.993\end{array}$ & $\begin{array}{r}250 \\
8,377 \\
4,500 \\
3,771 \\
47,893\end{array}$ & $\begin{array}{r}250 \\
8,377 \\
4,500 \\
3.771 \\
4 ., 679\end{array}$ & $\begin{array}{r}250 \\
8,377 \\
4,500 \\
3,771 \\
50,293\end{array}$ \\
\hline 80,183 & 80,163 & 81,499 & 84,170 \\
\hline $\begin{array}{r}1.496 \\
1.921 \\
2.349 \\
7.931 \\
6.707 \\
40.99\end{array}$ & $\begin{array}{r}1.732 \\
2.377 \\
3.092 \\
7.931 \\
7.457 \\
4.118\end{array}$ & $\begin{array}{r}2,221 \\
2,493 \\
3,082 \\
7,931 \\
8,388 \\
4 ., 152\end{array}$ & $\begin{array}{r}4.487 \\
5.544 \\
6.555 \\
19.840 \\
14.698 \\
101.841\end{array}$ \\
\hline $\begin{array}{r}8.182 \\
4 ., 971 \\
9.784 \\
14.691\end{array}$ & $\begin{array}{r}9,024 \\
\mathbf{5} 1.142 \\
10,828 \\
18,243\end{array}$ & $\begin{array}{r}9,630 \\
57,782 \\
11,558 \\
17,335\end{array}$ & $\begin{array}{r}20,368 \\
122,210 \\
24,442 \\
36,663\end{array}$ \\
\hline 121,360 & 129,100 & 136,362 & 233,608 \\
\hline
\end{tabular}

1.7 Fectlity Consturtion

17.1 Admuntetration

1.7.2 Front End / Recewing

1.7.3 Waste Prekgoing

1.7.4 Disposel Unt:

1.7.5 sto Development

Subtotal Direct Cocte (thems 1.7 .1 to 1.7.5) $\times 2$

1.7.8 Contrecter Overnead Fes (indireet Cout) Subletel Freiliny Construction (liem 1.7

1.8 Construetion Mensement

1.8 Contingency for Construction (for hem 1.781 .8 ) Totel Pre-Operational Costs

2.0 Operotion

2.1 Annuil Cost

2.1.1 Cell Construction

2.1.2 Administrwion (FTE)

2.1.3 Operntions

2.1.4 Mantionance

2.1.5 Environmentel Monitoring

2.1. Uvilies / Materiate

Subtoted Annuel Operational Cost (ivem 2.1)

2.1.7 Operevors Prom (5\% of annual costs)

Total Cperational Conte over 30 years

2.992
4.151
1.840
207
275
2.135
11.570
578

4.442

5,208

2,807

311

275

3,224

1. 287

813

812,403

7,402

5,994

4,159

518

413

4,475

22.921

1.148

723,268

37,534

13,340

19,889

2,627

2,200

18,044

93.635

4,682

3.0 Closure

3.1 Cover Emplecement

3.2 Demolition \& Decontemination

3.2.1 Administrution

3.2.2 Fromt-End Receiving

3.2.3 Weat Packang

3.3 Administrution (FTE)

3.4 Operritons

3.5 Environmental Monitoring

3.8 Uullice / Materials

3.7 Contingeney (for liems 3.1 to 3.6 )

3.8 Opernters Proit (5\% $x$ annual cost (items 3.1-3.6))

Total Closure Costs

4.0 Post-Closure

4.1 Environmental Monitoring

4.2 Sito Remediation

4.3 Securty

4.4 Maintenance

Total Post-Closure Costs

5.0 Community Bencilis and Compensation

5.1 Property Taxes (total over 40 years)

5.2 Annual Payments (totel over 30 yeans)

5.3 Additiond Paymente (totel over 3 years)

5.4 Community impect Payment

5.5 Annual Neighboring Community

Payments - (botel over 30 years)

Total Community Eenefitu a Compensation Costo

TOTAL FACIUTV costs (ltems 1.0 to 8.0)

UNT costs (\$1000/ cu fi)
1.342

449

981

1,174

18.154

920

2.750

2,609

20:9

1,418

36,890

\begin{tabular}{|c|c|c|}
\hline 1.910 & 3,048 & 15,852 \\
\hline $\begin{array}{r}520 \\
1,189 \\
1,531 \\
19,054 \\
1,403 \\
2,750 \\
3,952 \\
6.077 \\
1,615\end{array}$ & $\begin{array}{r}668 \\
1,247 \\
1,531 \\
24,101 \\
2,079 \\
4,125 \\
5,008 \\
10,451 \\
2,090\end{array}$ & $\begin{array}{r}1,346 \\
2,772 \\
3,277 \\
38,924 \\
9,945 \\
22,000 \\
11,004 \\
25,780 \\
5,156\end{array}$ \\
\hline 42,001 & 64,340 & 134,060 \\
\hline
\end{tabular}

5,400

5,440

1,082

835

12,767

5,400

8.100

8,160

1,623

1.252

19,135

12,767

(2)

71.732

7,200

450

3,000

1,800

8.18?

661,800

0.62
94,162

7,200

4,50
3,000

35,625

7,200

450

3,000

1,800

1,800

$\begin{array}{lr}109.612 & 149.078 \\ 836,139 & 1,112,968\end{array}$

0.65

0.40
43,200

43,520

8.656

6.676

102,062

589,491

12,000

450
3,000

3,000

687.41

$4,041,034$

0.29 
WORK BREAKDOWN STRUCTURE CASE J

50\% Decrease in Materials Cost.

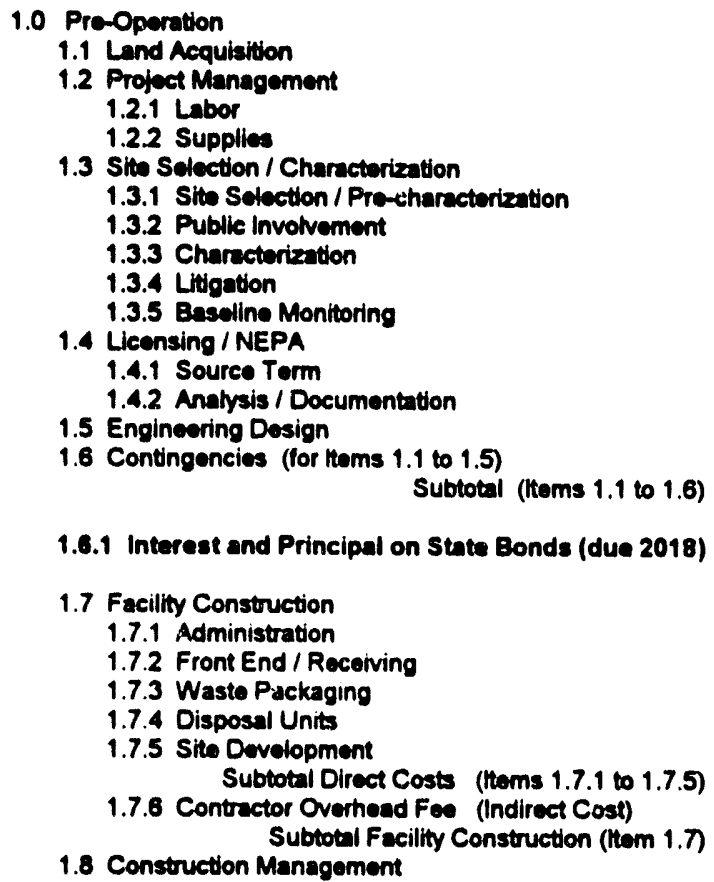

Total Pre-Operational Costa

2.0 Operation

2.1 Annual Cost

2.1.1 Cell Construction

2.1.2 Administration (FTE)

2.1 .3 Operations

2.1.4 Maintenence

2.1.5 Environmentai Monitoring

21.8 Utilites / Materiats Subtotal Annual Operational Costs (Item 2.1)

2.1.7 Opentor's Profit (5\% of annual costs) Total Operational Costs over 30 years

\begin{tabular}{|c|c|c|c|}
\hline $\begin{array}{r}\text { Small } \\
(x \$ 1000)\end{array}$ & $\begin{array}{l}\text { Medium } \\
(x \$ 1000)\end{array}$ & $\begin{array}{r}\text { Large } \\
(\times \$ 1000)\end{array}$ & $\begin{array}{c}\text { X-Large } \\
(x \$ 1000)\end{array}$ \\
\hline 3,000 & 3,000 & 3,393 & 4,200 \\
\hline $\begin{array}{r}4,000 \\
187\end{array}$ & $\begin{array}{r}4,000 \\
187\end{array}$ & $\begin{array}{r}4,000 \\
187\end{array}$ & $\begin{array}{r}4,000 \\
187\end{array}$ \\
\hline $\begin{array}{r}2,300 \\
5,000 \\
11,000 \\
1,000 \\
1,508\end{array}$ & $\begin{array}{r}2,300 \\
5,000 \\
11,000 \\
1,000 \\
1,508\end{array}$ & $\begin{array}{r}2,300 \\
5,000 \\
11,000 \\
1,000 \\
1,508\end{array}$ & $\begin{array}{r}2,300 \\
5,000 \\
11,000 \\
1,000 \\
1,508\end{array}$ \\
\hline $\begin{array}{r}250 \\
8,377 \\
4,500 \\
3,771 \\
44,893\end{array}$ & $\begin{array}{r}250 \\
8,377 \\
4,500 \\
3,771 \\
44,893\end{array}$ & $\begin{array}{r}250 \\
8,377 \\
4,500 \\
3,771 \\
45,286\end{array}$ & $\begin{array}{r}250 \\
8,377 \\
4,500 \\
3,771 \\
46.093\end{array}$ \\
\hline 76,132 & 76,132 & 76,790 & 77,141 \\
\hline $\begin{array}{r}1,498 \\
1,921 \\
2,348 \\
7,931 \\
6,707 \\
20,405\end{array}$ & $\begin{array}{r}1,732 \\
2,377 \\
3,062 \\
7,931 \\
7,457 \\
22,559\end{array}$ & $\begin{array}{r}2,221 \\
2,493 \\
3,062 \\
7,931 \\
8,368 \\
24,076\end{array}$ & $\begin{array}{r}4,487 \\
5,544 \\
6,555 \\
19,640 \\
14,696 \\
50,921\end{array}$ \\
\hline $\begin{array}{r}4,081 \\
24,486 \\
4,897 \\
7,346\end{array}$ & $\begin{array}{r}4,512 \\
27,071 \\
5,414 \\
8,121\end{array}$ & $\begin{array}{r}4,815 \\
28,891 \\
5,778 \\
8,667\end{array}$ & $\begin{array}{l}10,184 \\
61.105 \\
12,221 \\
18,331\end{array}$ \\
\hline 81,622 & 86,499 & 88,623 & 137,750 \\
\hline
\end{tabular}

1,481

4,151

1,840

10

275

1,633

2,483

474

298,723

2,22

5,208

2,807

155

275

2,509

13.175

659

416,002

3,701

5,994

4,159

259

413

3,330

17856

893

$682,4612,106,869$

3.0 Closure

3.1 Cover Emplacement

3.2 Demolition \& Decontamination

3.2.1 Administration

3.2.2 Front-End Receiving

3.2.3 Wasto Packaging

3.3 Administration (FTE)

3.4 Operations

3.5 Environmental Monitoring

3.6 Supplises / Utilities

3.7 Contingency (for ltems 3.1 to 3.6)

3.8 Operator's Profit (5\% $\times$ annual cost (items 3.1-3.6))

Total Closure Costs

4.0 Post-Closuro

4.1 Environmental Monitoring

4.2 Sito Remediation

4.3 Security

4.4 Maintenance

Total Post-Closure Costs
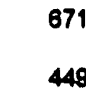

1.174

18,154

920

2,750

2,609

6.922

1,384

36,993

955

1.524

7,926

520

1,189

1,531

19,054

1,403

2,750

3,952

7.838

1,568

40,780

666

1,247

1,531

24,101

2,079

4,125

5,008

10.070

2,014

62,366

1.346

2,772

3,277

36,924

9.945

22,000

11,004

23.798

4,760

123,762

5,400

5,440

1,082

5,400

5,440

1,082

8,100

43,200

$8,160 \quad 43,520$

$1,623 \quad 8,656$

$1252 \quad 6.676$

12,767

12,767

19,136

102,052

5.0 Community Benefits and Compensation

5.1 Property Taxes (total over 40 years)

5.2 Annual Payments (total over 30 years)

5.3 Additional Payments (total over 3 years)

5.4 Community Impact Payment

5.5 Annual Nelghboring Community

Payments - (totel over 30 years)

Total Community Benofits a Compensation Costs

35,868

7,200

450

3,000

47.081

7,200

67,812

284,746

450

7,200

12,000

3,000

3,000

450
3,000

1,800

1,800

1,800

3,000

48,318

69.61

80.262

303.196

607,680

$\mathbf{6 4 3 , 7 8 8}$

$833,340 \quad 2,804,667$

UNIT costs (\$1000/cu in) 
WORK BREAKDOWN STRUCTURE CASE K

$50 \%$ increese in Materials Costs

\begin{tabular}{|c|c|c|c|}
\hline $\begin{array}{r}\text { Small } \\
(x \$ 1000)\end{array}$ & $\begin{array}{r}\text { Medium } \\
(x \$ 1000)\end{array}$ & $\begin{array}{r}\text { Large } \\
(\times \$ 1000)\end{array}$ & $\begin{array}{r}\text { X-Large } \\
(x \$ 1000)\end{array}$ \\
\hline 3,000 & 3,000 & 3,393 & 4,200 \\
\hline $\begin{array}{r}4,000 \\
187\end{array}$ & $\begin{array}{r}4,000 \\
187\end{array}$ & $\begin{array}{r}4,000 \\
187\end{array}$ & $\begin{array}{r}4.000 \\
187\end{array}$ \\
\hline $\begin{array}{r}2,300 \\
5,000 \\
11,000 \\
1,000 \\
1,508\end{array}$ & $\begin{array}{r}2,300 \\
5,000 \\
11,000 \\
1,000 \\
1,508\end{array}$ & $\begin{array}{r}2,300 \\
5,000 \\
11,000 \\
1,000 \\
1,508\end{array}$ & $\begin{array}{r}2,300 \\
5,000 \\
11,000 \\
1,000 \\
1,508\end{array}$ \\
\hline $\begin{array}{r}250 \\
8,377 \\
4,500 \\
3,771 \\
44,893\end{array}$ & $\begin{array}{r}250 \\
8,377 \\
4,500 \\
3,771 \\
44,893\end{array}$ & $\begin{array}{r}250 \\
8,377 \\
4,500 \\
3,771 \\
45,286\end{array}$ & $\begin{array}{r}250 \\
8,377 \\
4,500 \\
3,771 \\
46,093\end{array}$ \\
\hline 75,132 & 75,132 & 76,790 & \\
\hline $\begin{array}{r}1,498 \\
1,921 \\
2,348 \\
7,931 \\
6,707 \\
20,405 \\
4,081 \\
24,488 \\
4,897 \\
7,346\end{array}$ & $\begin{array}{r}1,732 \\
2,377 \\
3,062 \\
7,931 \\
7,457 \\
22,559 \\
4,512 \\
27,071 \\
5,414 \\
8,121\end{array}$ & $\begin{array}{r}2,221 \\
2,493 \\
3,062 \\
7,931 \\
8,368 \\
24,076 \\
4,815 \\
28,891 \\
5,778 \\
8,667\end{array}$ & $\begin{array}{r}4,48 \\
5,54 \\
6,55 \\
19,64 \\
14,69 \\
50,92 \\
10,18 \\
61,10 \\
12,22 \\
18,33\end{array}$ \\
\hline 81,622 & 85,499 & 88,623 & 137 \\
\hline
\end{tabular}

1.0 Pre-Operation

1.1 Land Acquisition

1.2 Project Management

1.2.1 Labor

1.2.2 Supplies

1.3 Situ Selection / Charecterization

1.3.1 Sito Seloction / Pre-cherectorization

1.3.2 Public involvement

1.3.3 Characterization

1.3.4 Litigation

1.3.5 Baseline Monitoring

1.4 Licensing / NEPA

1.4.1 Source Term

1.4.2 Analysis / Documentation

1.5 Engincering Desion

1.6 Contingencies (for ltems 1.1 to 1.5)

Subtotal (thems 1.1 to 1.6)

1.6.1 Interest and Principal on State Bonds (due 2018)

1.7 Facility Construction

1.7.1 Administration

1.7.2 Front End / Recoiving

1.7.3 Waste Packaging

1.7.4 Disposal Units

1.7.5 Site Dovelopment

Subtotal Direct Costs (itoms 1.7.1 to 1.7.5)

1.7.6 Contractor Overhead Foe (Indirect Cost)

Subtotal Facility Construction (ttom 1.7)

1.8 Construction Management

1.9 Contingency for Construction (for Hems $1.7 \& 1.8$ )

Total Pre-Operational Costs

81,622

86,499

2.0 Operation

2.1 Annual Costs

2.1.1 Coll Construction

2.1.2 Administration (FTE)

2.1.3 Operntions

2.1.4 Maintenance

2.1.5 Environmental Monitoring

2.1.6 Utilities / Materials

Subtotul Annual Operational Costs (Item 2.1)

2.1.7 Operator's Profit ( $5 \%$ of annual costs)

Total Operational Costs over 30 years

1.481

4.151

2,221

5.208

2,807

1,840

104
275

2.638

10,486

155

275

3,940

14.605

730

330,313

460,072

3,701

5,994

4,159

13.340

$\begin{array}{ll}413 & 1,314 \\ 5 & 2,200\end{array}$

$5.620 \quad 24,714$

$20.146 \quad 80.223$

$1,007 \quad 4,011$

3.0 Closure

3.1 Cover Emplacement

$634,601 \quad 2,527,635$

3.2 Demolition \& Decontamination

3.2.1 Administration

3.2.2 Front-End Recoiving

3.2.3 Wasto Packaging

3.3 Administration (FTE)

3.4 Operations

3.5 Environmontal Monitoring

3.8 Supplies / Utilities

3.7 Contingency (for Items 3.1 to 3.6)

3.8 Operntor's Profit (5\% $x$ annual cost (items $3.1-3.6$ ))

Total Closure Costs

4.0 Post-Closure

4.1 Environmental Monitoring

4.2 Site Remediation

4.3 Security

4.4 Maintenance

Total Post-Closure Costs

5.0 Community Benofits and Compensation

5.1 Property Taxes (total over 40 years)

5.2 Annual Payments (total over 30 years)

5.3 Additional Payments (total over 3 years)

5.4 Community Impact Payment

5.5 Annual Neighboring Community

Payments - (total over 30 years)

Total Community Benefits \& Compensation Coste

TOTAL FACILITY COSTS (Items 1.0 to 6.0 )

UNIT COSTS (\$1000/cu $\mathrm{t}$ )
67

449

18.154

920

2,750

2,609

6.922

1,384

36,993

5,400

5,440

1.082

835

12,757

955

1,524

7,926

520

1,189

1,531

19,054

1,403

2,750

3.952

2838

1,568

40,760

666

1,247

1,531

24.101

2.079

4,125

5,008

10.070

2,014

52,366

1,346

2,772

3,277

36,924

9,945

22,000

11.004

23.798

4.760

123,762

\section{5,400}

5,440

1,082

835

12,767

8,100

8,160

1,623

1252

19,136

43,200

43,520

8,656

6.676

102,052

35,868

7,200

47,081

7,200

67,81

7,200

284,746

450
3,000

450

12,000

$3,000 \quad 3,000$

3,000

1,800

1,800

1,800

3,000

48.316

69.631

$80.262 \quad 303.196$

539,240

688,859

$906,490 \quad 3,224,833$ 
WORK BREAKDOWN STRUCTURE CASE L

100\% Increase in Materials Costs

1.0 Pro-Oporation

1.1 Land Acquisition

1.2 Project Management

1.2.1 Labor

1.2.2 Supplies

1.3 Sito Selection / Characterization

1.3.1 Site Selection / Pre-characterization

1.3.2 Publle involvement

1.3.3 Charactorization

1.3.4 Litgation

1.3.5 Basaline Monitoring

1.4 Llconsing / NEPA

1.4.1 Source Term

1.4.2 Analysis / Documentation

1.5 Engineoring Design

1.6 Contingencies (for ltems 1.1 to 1.5)

Subtotal (Items 1.1 to 1.6)

Small

Modium

Large

X-Large

$(x \$ 1000)$

(x\$1000)

$(x \$ 1000)$

$x \$ 1000)$

1.6.1 Interest and Principal on State Bonds (due 2018)

3,000

4.000
18

2,300

5,000

11,000

1,000

1,508

250

8,377

4,500

3,771

44.893

76,132

1.7 Facility Construction

1.7.1 Administration

1.7.2 Front End/Receiving

1.7.3 Waste Packaging

1.7.4 Disposal Units

1.7.5 Sits Dovelopment

Subtotal Direct Costs (ltoms 1.7.1 to 1.7.5)

1.7.6 Contractor Overhead Fae (Indirect Cost) Subtotal Fecility Construction (tiem 1.7)

1.8 Construction Management

1.9 Contingency for Construction (for herns 1.721 .8 ) Total Pre-Operational Costs

\subsection{Operation}

2.1 Annual Costs

2.1.1 Cell Construction

2.1.2 Administration (FTE)

2.1.3 Operations

2.1.4 Maintienance

2.1.5 Environmental Monitoring

2.1.8 Utilites / Materials

Subtotal Annual Operational Costs (Item 2.1)

2.1.7 Operators Profit (5\% of annual costs)

Total Oparational Costs over 30 years

1,498

1,921

2,348

7,931

6.707

20.405

4,081

24.486

4,897

7,346

81,622

3,000

3,393

4,200

4.000

4,000

187

187

4,000

2,300

5,000

11,000

1,000

2,300

5,000

11,000

1,000

1,508

\section{0}

8,377

4,500

3,771

44.893

250

8,377

4,500

3,771

45.286

75,132

76,790

1.732

2,377

3,062

7,931

7.457

22.559

4.512

27.071

5,414

8.121

86,499

2.221

2,493

3,062

7,931

8,368

24.076

4.815

28.891

5,778

8,667

88,623

187

2,300

5,000

11,000

1,000

1,508

250

8,377

4,500

3,771

46.093

77.141

4,487

5,544

6,555
19,640

14,696

50.921

10,184

61.105

12,221

18,331

137,760

1.481

4,151

2,221

5,208

2,807

1.840

104
275

3.137

10.988

549

346.107

155

275

4,655

15.321
768

482,608

3,701

5,994

4,159

4,159
259

259
413

21.291
1,065

670,676

18,767

13,340

19,889

1,314

2,200

31,383

86.893

4,345

3.0 Closure

3.1 Cover Emplacement

3.2 Demolition \& Decontamination

3.2.1 Administration

3.2.2 Front-End Recoiving

3.2.3 Waste Packaging

3.3 Administration (FTE)

3.4 Operations

3.5 Environmental Monitoring

3.6 Supplies / Utiltites

3.7 Contingency (for thems 3.1 to 3.6 )

3.8 Operator's Profit (5\% $x$ annual cost (items 3.1-3.6))

Total Closure Costs

4.0 Post-Closure

4.1 Environmental Monitoring

4.2 Site Remediation

4.3 Security

4.4 Maintenance

Total Post-Closure Costs

5.0 Community Benefits and Componsation

5.1 Property Taxes (total over 40 years)

5.2 Annual Payments (total over 30 years)

5.3 Additional Payments (total over 3 years)

5.4 Community Impact Payment

5.5 Annual Neighboring Community

Payments - (total over 30 years)

Total Community Benofits \& Compensation Costa

TOTAL FACILIT costs (Items 1.0 to 6.0)

UNIT costs (\$1000/ cu $\mathrm{n}$ )
671

449

96

1.174

18.154

920

2.750

2.609

6.922

1,384

36,993

955

520

1.189

1,531

19.054

1,403

2.750

3.952

2.838

1.568

40,780

1,524

668

1,247

1,531

24,101

2.079

4,125

5,008

10.070

2,014

52,366

5,400

5,440

1,082

835

12,767

8,100

8,160

1,623

1,252

19,136

47,081

35,868

7,200

450

3,000

1,800

48,318

665,034

0.63
450

3,000

1,800

69.531

711,394

0.47
67,812

7,200

450

$3,00 n$

1,800

80.262

0.39

0.26 
WORK BREAKDOWN STRUCTURE CASE M

NII Salaries Fixed at $\$ 140 \mathrm{~K} / \mathrm{yr}$

1.0 Pre-Operation

1.1 Land Acquisition

1.2 Project Managoment

1.2.1 Labor

1.2.2 Supplies

1.3 Sito Solection / Charactorization

1.3.1 Sito Selection / Pre-charactorization

1.3.2 Public Involvement

1.3.3 Charectarization

1.3.4 Litigation

1.3.5 Baselino Monitoring

1.4 Licensing / NEPA

1.4.1 Source Term

1.4.2 Analysis/ Documentation

1.5 Engineering Design

1.6 Contingoncies (for Hems 1.1 to 1.5)

Subtotal (thems 1.1 to 1.6)

\begin{tabular}{|c|c|c|c|}
\hline $\begin{array}{r}\text { Small } \\
\times \$ 1000)\end{array}$ & $\begin{array}{l}\text { Medium } \\
(x \$ 1000)\end{array}$ & $\begin{array}{r}\text { Large } \\
(\times \$ 1000)\end{array}$ & $\begin{array}{r}\text { X-Large } \\
(x \$ 1000)\end{array}$ \\
\hline 3,000 & 3,000 & 3,393 & 4,200 \\
\hline $\begin{array}{r}4000 \\
187\end{array}$ & $\begin{array}{r}4000 \\
187\end{array}$ & $\begin{array}{r}4000 \\
187\end{array}$ & $\begin{array}{r}4000 \\
187\end{array}$ \\
\hline $\begin{array}{r}2,300 \\
5,000 \\
11,000 \\
1,000 \\
1,508\end{array}$ & $\begin{array}{r}2,300 \\
5,000 \\
11,000 \\
1,000 \\
1,508\end{array}$ & $\begin{array}{r}2,300 \\
5,000 \\
11,000 \\
1,000 \\
1,508\end{array}$ & $\begin{array}{r}2,300 \\
5,000 \\
11,000 \\
1,000 \\
1,508\end{array}$ \\
\hline $\begin{array}{r}250 \\
8,377 \\
4,500 \\
3,771 \\
44,893\end{array}$ & $\begin{array}{r}250 \\
8,377 \\
4,500 \\
3,771 \\
44,893\end{array}$ & $\begin{array}{r}250 \\
8,377 \\
4,500 \\
3,771 \\
45,286\end{array}$ & $\begin{array}{r}250 \\
8.377 \\
4.500 \\
3.771 \\
46.093\end{array}$ \\
\hline 78,132 & 78,132 & 76,790 & 77,141 \\
\hline $\begin{array}{r}1,498 \\
1,921 \\
2,348 \\
7,931 \\
6,707 \\
20,405 \\
4,081 \\
24,486 \\
4,897 \\
7,346\end{array}$ & $\begin{array}{r}1,732 \\
2,377 \\
3,062 \\
7,931 \\
7,457 \\
22,559 \\
4,512 \\
27,071 \\
5,414 \\
8,121\end{array}$ & $\begin{array}{r}2,221 \\
2,493 \\
3,062 \\
7,931 \\
8,368 \\
24,076 \\
4,815 \\
28,891 \\
5,778 \\
8,667\end{array}$ & $\begin{array}{r}4,487 \\
5,544 \\
6,555 \\
19,640 \\
14,696 \\
50,921 \\
10,184 \\
61,105 \\
12,221 \\
18,331\end{array}$ \\
\hline 81,622 & 85,499 & 88,623 & 137,7 \\
\hline
\end{tabular}

1.6.1 Interest and Principal on State Bonds (due 2018)

1.7 Facility Construction

1.7.1 Administration

1.7.2 Front End / Recoiving

1.7.3 Wasto Packaging

1.7.4 Disposal Unit

1.7.5 Sito Dovelopment

Subtotal Direct Costs (thems 1.7 .1 to 1.7.5)

1.7.6 Contractor Overhasd Fee (Indirect Cost) Subtotul Facility Construction (ttem 1.7)

1.8 Construction Management

1.9 Contingency for Construction (for Horns 1.7 \& 1.8)

Total Pre-Operational Costs

81,622

86,499

\begin{tabular}{rrrr}
1,481 & 2,221 & 3,701 & 18,767 \\
8,680 & 11,200 & 12,880 & 29,820 \\
1,840 & 2,807 & 4,159 & 19,889 \\
104 & 155 & 259 & 1,314 \\
275 & 275 & 413 & 2,200 \\
2,135 & 3,224 & 4,475 & 18,044 \\
14,514 & 19,882 & 25,887 & 90,033 \\
\hline 726 & 994 & 1,294 & 4,502 \\
67,182 & 626,291 & 815,429 & $2,836,054$
\end{tabular}

2.0 Operation

2.1 Annual Costs

2.1.1 Coll Construction

2.1.2 Administration (FTE)

2.1.3 Operations

2.1.4 Maintonance

2.1.5 Environmental Monitoring

2.1.6 Ualities / Materials

Subtotal Annual Operational Costs (them 2.1)

2.1.7 Operator's Proffe (5\% of annual costs)

Total Operational Costy over 30 years

467,182

628,291

$2,8,836,054$

3.0 Closure

3.1 Cover Emplacement

674

955

1,524

7,926

2 Demolition Decontamination

3.2.1 Administration

3.2.2 Front-End Receiving

3.2.3 Wasto Packaging

449

961

1,174

520

1.189

1,531

35,000

3.3 Administration

3.5 Environmental Monitoring

3.6 Utilities / Materials

3.7 Contingency (for litems 3.1 to 3.6)

3.8 Operator's Profit (5\% $x$ annual cost (items 3.1-3.6))

2,750

38,400

1,403

2,750

3,952

2.600

11.133

12.175

2,435

666

1.247

1,531

47,600

2,079

4,125

5,008

15.945

3,189

63,310

82,914

1,346

2,772

3,277

74,200

9,945

22,000

11,004

$\frac{33.117}{6,623}$

57,893

172,211

4.0 Post-Closure

4.1 Environmental Monitoring

5,400

5,400

8,100

43,200

5,440

5,440

1,082

8,160

4.2 Security

4.4 Maintenance

Total Post-Closure Coste

12,767

12,767

43,520
8,656

6.676

$19,136 \quad 102,062$

5.0 Community Benemts and Compensation

5.1 Property Taxes (total over 40 years)

5.2 Annual Payments (total over 30 years)

5.3 Additional Payments (total over 3 years)

5.4 Community Impact Payment

5.5 Annual Neighboring Community

Payments - (total over 30 years)

Total Community Benefits \& Compensation Costs

35,868

7,200

47,081

67812

284,746

450

7,200

7.200

12,000

$450 \quad 450$

3,000

3,000

3,000

3,000

1,800

1,800

$1,800 \quad 3,000$

48.316

62.531

$80.262 \quad 303,196$

688,008

$877,627 \quad 1,116,867 \quad 3,582,311$

0.68

0.68

0.47

0.26 


\section{Appendix B}

Massachusetts Scope of Work Statement 


\title{
Estimating Costs of Disposal Alternatives for Massachusetts
}

\author{
November 16, 1993
}

\author{
Scope of Work
}

\section{A.Background}

The Massachusetts Low-Level Radioactive Waste Management Board (the "Board") is charged by state and federal law to provide for the management (including disposal) of low-level radioactive waste (LLRW) generated in the Commonwealth from various academic, health care, commercial, government and utility users of radioactive materials. The Board must make decisions regarding the short-term and long-range management of this waste, including the possible determination to initiate siting for an LLRW disposal facility within the Commonwealth.

Out-of-state options for LLRW management may be available at some future date through contracts or regional compact arrangements with other states. At the present time, however, all states and compact regions with current or developing disposal capacity have adopted explicit statutory prohibitions or have communicated an unwillingness to accept LLRW from outside their state or region.

The Board has asked the National Low-Level Waste Management Program of the U.S. Department of Energy to develop a report on instate disposal facility costs and costs incurred by various states and regional compacts developing facilities outside Massachusetts. This scope document describes the tasks which will develop cost estimates to be included in the report.

\section{B. Ohjectives}

The objectives of this study are to:

- develop planning-level life cycle cost (PLCC) estimates (November, 1993 dollars) for four sizes of LLRW disposal facilities within Massachusetts;

- develop PLCC estimates for non-Massachusetts LLRW disposal facilities; and

- summarize the statutory provisions in compact and state law, and/or current expressed state or compaci policies (i.c., votes or declarations by state LLRW management officials or Governors) regarding out-of-state access. 


\section{C.Description of Tasks}

This project is divided into five tasks. They are summarized as follows:

1. Develop a draft annotated outline that reflects the format and content of the report for Task 3. Any comments concerning assumptions or tasks should be incorporated into this document.

2. Conduct a literature search of relevant available economic publications, reports, and documents, including those produced by states currently siting LLRW disposal facilities.

3. Prepare estimates of PLCCs, both in total and in unit disposal costs, for the four in-state facility sizes which incorporate the one technology option (i.e., "state-of-the-art" above-ground vaults with second enginecred structure), using the assumptions in Part D, to the extent possible, as the bases for costs generated.

4. Survey all regional compact and unaffiliated host states currently developing LLRW disposal facilities. Data collected should include:
a. identification of PLCC estimates, both in total and in unit disposal costs, for each site. To the extent possible, these costs should be comparable with the costs identified in the Part D assumptions, or identified if not applicable or incalculable;
b. statutory provisions (both state and compact law) relating to the acceptance or non-acceptance of Massachusetts LLRW;
c. if no statutory provisions exist regarding access, identify current state/compact policy (votes, declarations, etc.) through interviews with state/compact officials, regarding existing access policies;
d. estimates of access costs (entry fces, annual charges, surcharges, etc.);
e. transportation costs; and
f. other identifiable charges for out-of-state disposal.

5. Develop Draft and Final versions of two reports.

\section{Assumptions to be Incorporated in Analytical Tasks} PLCCs.

The following list of assumptions should be used to the extent possible for estimating

1. In-state facility sizes: ${ }^{1}$

\#1. Massachusetts-only: 35,000 cubic feet/year;

\#2. Massachusetts-only: 50,000 cubic feet/year;

\#3. Small regional: 80,000 cubic feet/year; and

\#4. Large regional: 476,000 cubic feet/year.

2. The minimum facility land area for these sizes is:

a. Massachusetts-only facility sizes $=100$ acres;

b. Small regional facility $=130$ acres; and 


\section{c. Large regional facility $=\mathbf{4 2 0}$ acres.}

3. The major criteria and data used for all facility sizes are:

a. the facility would operate and accept waste for 30 years;

b. the waste stream would be homogencous for the 30-year operating cycle;

c. total LLRW inventory is estimated based on Management Board annual surveys;

d. decommissioning wastes available for disposal at the facility from two commercial power reactors and other facilities are assumed to total 450,000 cubic feet of Class $A$, $B$, and C LLRW, and are included in the annualized volumes given in item $D(1)$;

e. the disposal technology employed at the site for all waste classes would allow monitoring and retrieval of the waste in intact containers; and

f. no significant commitment of land would be required for other types of activities at the site not directly related to the disposal function. Sufficient land area would be available for office and lisboratory space in connection with any affiliated activity, such as an LLRW minimization rescarch center.

3. Annual LLRW disposal volumes:

a. Annual LLRW disposal volumes for facility size \#1 would contribute 600,000 cubic feet of Class A, B, and C LLRW to the total site inventory over 30 years; total site inventory from annual shipments and decommissioning would be $1,050,000$ cubic feet.

b. Annual LLRW disposal volumes for facility size \#2 would contribute 1,050,000 cubic feet of Class A. B, and C LLRW to the total site inventory over 30 years; total site inventory from annual shipments and decommissioning would be 1,500,000 cubic feet.

c. Facility size \#3 would have a total site inventory from annual shipments and decommissioning of $2,4(0),(0) 0$ cubic feet.

d. Facility size \#4 would have a total site inventory from annual shipments and decommissioning of 14,0(N),(00) cubic feet.

4. Facility techrology is assumed to be above-ground vaults with a second engineered structure, comparable to the state-of-the-art designs under development in several compact regions. ${ }^{2}$

5. State siting costs are tixed at $\$ 45,(\%)(0)(0)$, and assume bonding at Massachusetts bond rates for 25 years.

6. Facility location is assumed to meet the requirements of 10 CFR 61 and the Massachusetts LLRW facility siting regulations.

7. Facility design shall allow for segregation of LLRW containing short-lived and long-lived radionuclides. ${ }^{3}$

8. For the purpose of this analysis, conventional monitoring equipment is assumed to be utilized over the opcrating and institutional control phases of the facility. ${ }^{4}$ 
9. The facility would be operated by a private contractor according to the following conditions:

a. The operational period would be $\mathbf{3 0}$ years;

b. The post-closure period would be 10 years;

c. The private operator would be limited to receiving reasonable expenses for facility operation;

d. Funds to cover institutional control costs (i.c., facility maintenance) would be incorporated into the fee structure for facility operation.

e. While the operator would also be expected to include in the fee structure funds to cover contingent liability during the institutional control period, political and actuarial data to estimate such costs is unknown at this time. Therefore, for the purposes of this analysis, contingent liability costs will be assumed to be a constant of zero for both in-state and out-of-state facilitics. The Management Board may define these costs as part of any subsequent analysis it may perform.

10. The institutional control period would be $\mathbf{3 0 0}$ years. $^{5}$

11. Because the insurance industry has not yet developed actuarial data to identify premiums for various types of facility insurance (c.g. All-Risk Property, General Liability, Environmental Impairment, and Nuclear Energy Liability), for the purpose of this analysis, the costs associated with the facility operator providing such financial assurance will be considered to be undefinable. Therefore, the contractor will assume said costs to be zero, and the Management Board may define these costs in any subsequent analyses. ${ }^{6}$

12. Community benefits and compensation:

a: Payments to the "site" community ${ }^{7}$ would include:

(1) payments of property taxes from the period commencing with the issuance of a facility license, and ending with the transfer of such license to the Management Board. For the purpose of this analysis, said payments shall assume a commercial tax rate of $\$ 18$ per thousand at full fair market (i.e., $100 \%$ ) valuation of land plus improvements;

(2) payments during facility operation of $\$ 240,000$ annually (during facility operation) for site sizes $\# 1, \# 2$, and $\# 3$; and $\$ 400,000$ annually for site size \#4;

(4) payments of $\$ 150,000$ per year, pro rata, for the first three years of facility operation; ${ }^{8}$ and

(5) $\$ 3,000,000$ to fund a one-time site community "impact" payment as well as other negotiated compensation (i.e., road reconstruction, payments for emergency services, property value guarantees, etc.).

b. Payments to one "neighboring" community ${ }^{10}$ would include:

(1) $\$ 60,000$ annually (during facility operation) for site sizes $\# 1, \# 2$, and \#3.

(2) $\$ 100,000$ annually for site size $\# 4$. 
13. Life cycle costs will include entry fees, if applicable.

14. For facility sizes \#3 and \#4, assume that all facility siting costs ( $\$ 45$ million) would be paid by out-of-state generators from states that would be invited to join a regional compact.

\section{E. Deliverables}

Deliverables shall include the following:

1. An annotated outline reflecting the format and content of the report for Task 3 of Part C.

2. Two Draft and Final reports, one encompassing Tasks 2 and 4 , and one covering Task 3 of Part C. The report for Task 3 shall, for each facility size, include cost estimating summaries and related details for the aboveground enginecred disposal technology option assumed for this analysis. In addition, the Draft and Final reports shall include graphs that plot cost versus facility size. A 10-15 page narrative shall summarize the data, basis, and assumptions of the analysis for Task 3 .

3. Twenty-five copies of the Draft and Final reports shall be provided to the Management Board.

F. Contract Schedule

1. The annotated outline shall be submitted on $12 / 1 / 93$.

2. The Draft reports shall be delivered on or before $1 / 1 / 94$.

3. The Final reports shall be submitted on or before $1 / 15 / 94$.

Endnotes:

1. The last three facility sizes are discussed in the draft LLRW Management Plan, section 15.9 (attached). The first size (35,000 cubic fect) results from the Management Board's latest projection of annual volume requiring disposal in a licensed disposal facility, which reflects a 10,000 cubic feet annual reduction from earlier projections.

2. Facility life cycle costs are to some extent dependent upon the type of technology chosen for the disposal facility design. In Massachusetts, such design selection is the responsibility of the site community, not the Board. However, because facility technologies will not influence the evaluation of in-state versus out-of-state economies, for this study, the one disposal technology selected for analysis is the technology employing above-grade vaults with a second engineered structure, comparable to the statc-of-the-a Jesigns planned for Pennsylvania, Illinois, North Carolina, or Nebraska. 
3. The Management Board has recommended a segregation of short- and long-lived LLRW, to enhance safety and efficiency in any retricval activity that may later be required. In addition, segregation will aid the Board in fulfilling the requirements of state law (M.G.L. c. 111H, section 46), that stipulates: "the institutional control period shall not be less than the minimum time required for any LLRW present at the site to decay to the maximum concentrations above natural backgrou. Id levels permitted to be released into air or water in unrestricted areas under federal and state law."

4. Monitoring devices are required pursuant to M.G.L. c.111H that can be maintained (or replaced when necessary) in order to provide the capability to monitor waste packages throughout the life of the facility.

5. See M.G.L. c.111H, section 46 requirement referenced in Endnote 3.

6. The Management Board has recommended that the operator of any LLRW disposal facility sited in Massachusetts should be required to purchase or otherwise arrange to carry the following:
a. All-Risk Property Insurance to insure the facility itself (including costs of replacement of the buildings and equipment) in an amount equal to the facility's replacement cost. or the maximum amount available, whichever is less:
b. Comprehensive General Liability Insurance, with minimum limits of $\$ 25$ million per occurrence and \$25 million in the aggregate;
c. Environmental Impairment Liability Insurance, with minimum limits of $\$ 10$ million.
d. Nuclear Energy Liability Insurance, with minimum limits equal to \$25 million.

7. Site community compensation is referenced in two ways in state law. First, certain types of compensation are explicitly required, such as the payment of real property taxes, and annual payments during facility operation. Other lorms of eompensation and impact payments are left to negotiations between the site community and the lacility operator, and may include property value protections, infrastructure improvements, and large, one-time community payments.

8. State law requires that in addition to the payments for property taxes, the annual operating fees, and any negotiated agreements, the operator also pay $\$ 150,00 X)$ per year, pro rata, to the site community during the period commencing with the opening of the facility and ending tive years after the issuance of a facility license. For the purpose of this analysis, it is assumed that litigation will delay the facility opening for two years.

9. See description of various community compensation and impact payments in Endnote 7.

10. A "neighboring community" is defined in state law as a community, other than a site community, which according to the most recent census, has at least $20 \%$ of its population residing within three miles of any facility site. The statute specifies the type and level of payments to such a community. 


\section{Appendix C \\ PLCC Estimates for the Retrieval of Long-lived LLRW}

C-1 


\section{Appendix C \\ PLCC Estimates for the Retrieval of Long-lived LLRW}

\section{C-1 INTRODUCTION}

The purpose of this appendix is to provide the PLCC estimate for retrieving long-lived radioactive waste from LLRW disposal facilities after a 300-year post-closure period. The PLCC estimates consist of the capital and operating costs for constructing a new canister receiving and packaging facility; excavating the disposal vaults and retrieving the canisters; inspecting and packaging the canisters, including repackaging $5 \%$ of the retrieved canisters; preparing the canisters for shipment: and restoring the site. Estimates are presented in first quarter 1994 dollars and use the same administration, utilities, supplics and materials rates as the operational disposal facilities. Transportation and re-disposal costs are not estimated because they cannot be defined at this time. A summary of the PLCC retrieval estimate is shown in Table C.1.

The scenario for retrieving long-lived LLRW is developed in accordance with Massachusetts law M.G.L. c. $111 \mathrm{H}$ s.46 which requires that any disposed waste must decay to an innocuous level before the institutional control period ends. This law states:

... the institutional control period shall not be less than the minimum time required for any LLRW present at the site to decay to the maximum concentrations above natural background levels permitted to be released into the air or water in unrestricted areas under federal and state law...

Using this criteria, it is assumed that the institutional control period is 300 years and any LLRW that has not decayed to an acceptable level must be retrieved. No assumptions have been formed for the disposition of the waste after retricval. Accordingly, the Commonwealth of Massachusetts would use whatever technological advancements have been made during the postclosure period for disposing the retrieved LLRW.

The scenario for waste retrieval in this study is for the sole purpose of providing a basis for this cost estimate to be used as a tool in evaluating waste management options. Given the uncertainties presented by a 300 -year time lapse, the actual retrieval activity might be different from that described here. Therefore, these PLCC estimates may vary significantly from actual costs and do not represent an enginecring design cost analysis.

This appendix is divided into four sections. Section C-1 is the background and purpose for estimating the cost of retrieving the long-lived LLRW. Section C-2 is a description of the retrieval facilities and details the assumptions used for the waste retrieval process as a basis for the PLCC. Section C-3 describes the cost estimating method and Section C-4 discusses the conclusions. 
Table C-1. PLCC Summary Costs for Retrieval.

1.0 Vault Excavation/Rotrioval
1.1 Cloar and Grub
1.2 Excavate cap
1.3 Romove roof panele
1.4 Rotrievo/transport waste canisters
1.5 Utilitios/Supplies
Subtotal diroct costs (Itoms 1.1-1.5)-
1.6 Contractor overhead (fiold costs, Homs 1.1-1.5)
Subtotal excavation/retrioval
1.7 Administration (FTE)
1.8 Construction management (Items 1.1-1.6).
1.9 Contingencies (Hems $1.1-1.8$ )

Total Excenvation/Caniater Removal (Item 1.0)

2.0 Facility Construction

2.1 Canister Packaging Facilities

2.1.1 Site Development

2.1.2 Administration

2.1.3 Canister Receive and Inspect

2.1.4 Canister Packaging and Transfer Transfer Subtotal direct costs (liem 2.1) (them

2.2 Contractor overhead (Field costs, Hem 2.1) 2.1)

2.3 Administration (FTE)

Subtotal facility construction (thems 2.1-2.2)

2.4 Construction Management (ltem 2.1 and 2.2) 2.2)

2.5 Contingencies (Items 2.1-2.4)

Total Facility Conetruction (Mem 2.0)

3.0 Canister Packaging Operations

3.1 Administration (FTE)

3.2 Materials

3.3 Utilities/Supplies

3.4 Maintenance

Totw Peckeging Operations (fiom 3.0)

4.0 Site Closure

4.1 Decommission Waste Packaging Facilities

4.1.1 Administration

4.1.2 Canister Receive and Inspect

4.1.3 Canister Packaging and Transfer Transfer

4.1.4 Restore sito

4.2 Vautt Closure

Subtotal Decommissioning (Item 4.1) (Item

4.2.1 Place roof panels

4.2.2 Cap material/cell beckfill

4.2.3 Concrete seal

4.2.4 Imported material

4.2.5 Restore disturbed areas

4.2.6 Restore vegetation

Subtotal Cell Closure (titem 4.2) (them

4.3 Contractor overhead (field costs, Items 4.1 and 4.2)

Subtotal site closure (ltems 4.1-4.3) (thems

4.4 Administration (FTE)

4.5 Utilities/Supplies

4.6 Construction Management (tems 4.1 - 4.3) 4.3)

4.7 Contingencies (Items 4.1-4.6)

Totel Sito Clowure (ftem 4.0)

TOTAL RETPUEVAL COSTS

UNT COST ( $\times \$ 1000 /$ canister

UNIT COST \& $\$ 1000 /$ cu TI

$\begin{array}{rrrr}\begin{array}{r}\text { SMALL } \\ (x \$ 1000) \times\end{array} & \begin{array}{r}\text { MEDIUM } \\ (x \$ 1000\end{array} & \begin{array}{r}\text { LARGE } \\ (x \$ 1000)\end{array} & \begin{array}{r}x-L A R G E \\ (x \$ 1000)\end{array} \\ 4 & 5 & 7 & 42 \\ 87 & 119 & 185 & 1,123 \\ 133 & 187 & 297 & 1,741 \\ 4,121 & 5,818 & 9,212 & 54,057 \\ 4,897 & 6,860 & \frac{7,558}{11,257} & \frac{5,198}{62,161} \\ \frac{979}{5,877} & \frac{1,372}{8,233} & \frac{2,251}{3,509} & \frac{12,432}{74,594} \\ 2,183 & 2,236 & 4,906 & 12,227 \\ 1,175 & 1,647 & 2,702 & 14,919 \\ \frac{2,309}{11,544} & \frac{3,029}{15,144} & \underline{5,279} & \frac{25,435}{127,174}\end{array}$

2,688

2,933

810

2,854

4,840

11.437

$\frac{2,287}{13,724}$

803

2,745

4.318

21,560

$\begin{array}{rr}3,717 & 8,867 \\ 1,114 & 1,777 \\ 4,068 & 6,885 \\ 6,150 & 9,223 \\ 15,049 & 26,753 \\ \frac{3,010}{18,059} & \frac{5,351}{12,103} \\ 911 & 2,553 \\ 3,612 & 6,421 \\ \frac{5,646}{28,228} & \frac{10,269}{51,347}\end{array}$

3,088

3,140

2,065

2,588

1.048

1,767

1,031

8,840

7,214

3,272

5,399

2,205

18,050

\section{0,601}

19,191

18,899

5,108

63,799

230

243

1,427

1,452

1,452

$3,1 \frac{47}{10}$

$3,1 \frac{59}{81}$

334

2,034

1,845

$\frac{87}{300}$

3,443

2,767

363

$7, \frac{106}{106}$

160

227

359

2,105

2,355

3,625

304

126

$8, \frac{149}{664}$

3,154

$1 \frac{3,924}{1,956}$

1,956

1,016

3,785

6,420

32,101

47,919

54,509

85,224

274,421

4.95

3.98

3.93

216

0.07

0.07

0.04 


\section{C-2 DESCRIPTION OF RETRIEVAL FACILITY}

\section{C-2.1 Design Basis}

The following assumptions are used as a guide for preparing a PLCC estimate for retrieval of long-lived waste. The conditions for the retrieval estimate, such as the vault configuration, work shifts and time-value of money, are assumed to be the same as for the disposal estimate.

- $\quad 50 \%$ of LLRW is short-lived; 50\% of LLRW is long-lived and was segregated in separate disposal vaults. Therefore, half of the disposal cells are exhumed.

- Vaults containing long-lived LLRW are exhumed after a 300-year institutional control period. The canisters are retrieved, inspected, and readied for shipment. The cells are reused for disposal of onsite materials. The site is restored to its condition prior to opening the vaults.

- PLCC estimates only apply to waste retrieval and site restoration, not to re-disposal or transportation to another location.

- Waste retrieval, canister packaging, and site restoration takes a maximum of 5 years.

- Only part of the cap material is removed from the disposal vaults containing long-lived LLRW to permit entry from the top. The cap material is removed from the top of the cells, but the cap sideslope remains in place.

- Access to cells is by a 14-foot-wide perimeter haul road built on top of the cap.

- Excavated vault materials (backfill, concrete roof panels, or other cell material which is not contaminated) are stored onsite during retrieval and will be disposed of onsite.

- The concrete pancls making up the cell roofs are removed by an overhead crane. Panels are placed into an adjacent evacuated cell for disposal as they are removed.

- Waste canisters in each cell are removed by an overhead crane, placed on surface transport vehicles, and sent to an onsite recciving and packaging facility.

- A packaging facility is constructed onsite to: receive, handle, inspect and assay retrieved canisters; overpack canisters as needed; and process secondary wastes.

- Waste handling capacities and equipment demands for the packaging facility assumes that $5 \%$ of the retrieved waste needs repackaging.

- All waste will remain in the original waste canisters. Canisters requiring repackaging will not be opened before being be overpacked in larger canisters. 
- Overpack canisters are concentrically square with the retrieved canisters, with outside dimensions of $8.5 \times 6.5 \times 6.5 \mathrm{ft}^{3}$ and 9-inch-thick concrete walls. The void and top of all canisters are sealed with grout.

- All retrieved waste canisters are labeled, manifested, and sent to the laydown area.

- Exhumed disposal cells are filled with the sand backfill remaining after the canisters are removed, concrete roof panels, and excavated cap material. Clean soil is brought to the site to fill any remaining cell volume. The top of each cell is sealed with one foot of concrete.

- The exhumed vaults will be capped with four feet of borrow material contoured with the slopes of the original cover and the vegetation will be restored to pre-excavation conditions.

- Retrieval, inspection, and repackaging activities will generate secondary waste equivalent to $2 \%$ of the retricved waste volume. This waste will be grouted into empty concrete overpack canisters.

- No leakage of radioactivity to the outside of the cells has occurred and no environmental investigations or restoration of soil or groundwater is required at the site.

- Retrieval facilities are decontaminated and demolished after all canisters have been packaged. The overall site is restored to conditions prior to waste retrieval.

\section{C-2.2 Description of Facility}

The conceptual LLRW retrieval facility is comprised of three major components: the retrieval area, a packaging facility, and a laydown area. An oblique view of the conceptual vault excavatiun and retrieval area is shown in Figure $\mathrm{C}-1$. The conceptual canister receiving and packaging facility layout is shown in Figure C-2.

The retrieval area consists of the area at and around the vaults that will be excavated to facilitate waste canister retrieval. The retrieval area contains the excavated vaults, working areas for removal activities and equipment, and stockpiles for temporary staging of excavated and/or borrow material. After retrieval of the waste canisters, the exhumed cells will be used for disposing of the roof and cap materials. The grout plant associated with the packaging facility can be used to supply concrete to seal the vault cells during closure.

For waste retrieval, the caps of the vaults will be removed. A perimeter road will be built around each vault to be exhumed. An overhead crane will lift off the concrete covers, and then lift out each canister. The empty vaults, used to dispose of excavated construction material, will be capped with four feet of earthen material. 


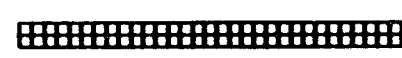

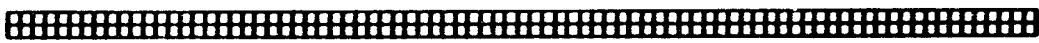
曲

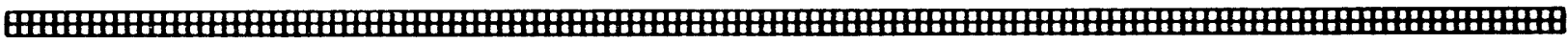

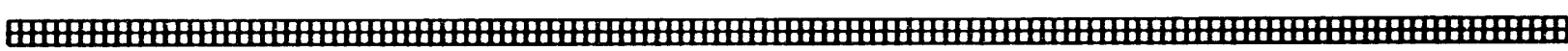

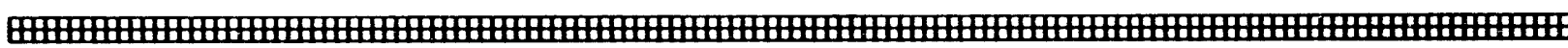

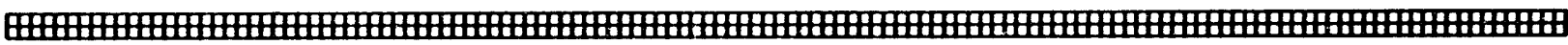

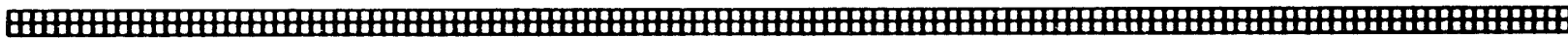
CAMISTER LAYOOW AREA
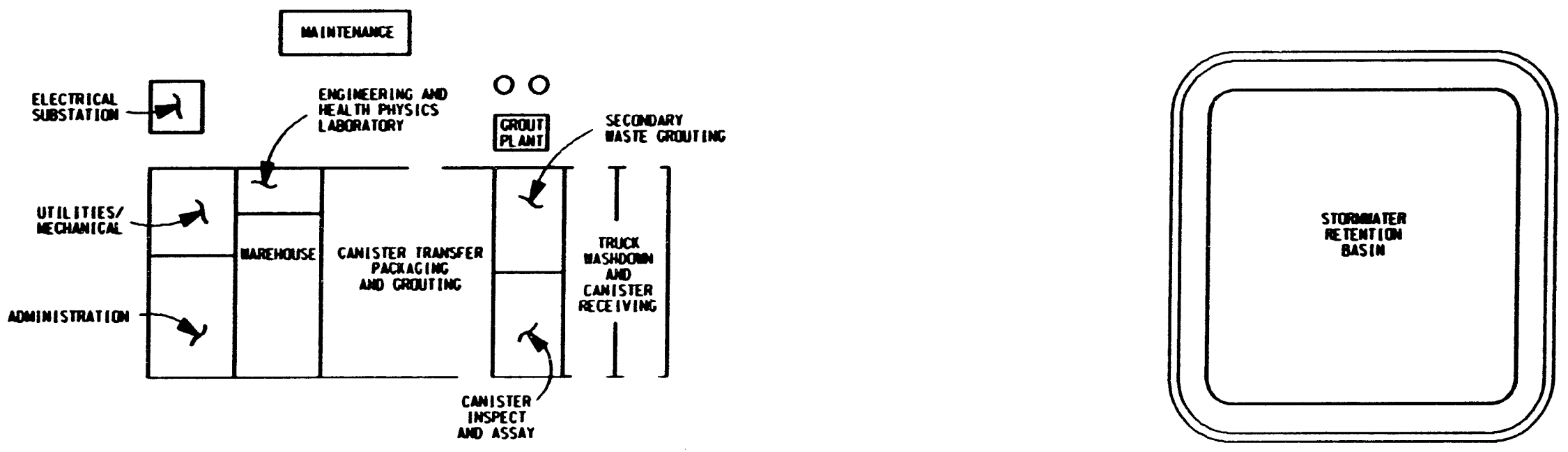

FIGURE C-2. PLAN VIEW OF CANISTER RECEIVING AND PACKAGING FACILITY SCALE $=1 *=100$ 
The canister receiving and packaging facility consists of areas for administration; security; truck receiving and wash down; canister inspection and assay; canister repackaging; an analytical laboratory for engineering, health physics, and site monitoring; a grout plant; maintenance building; warehousing; parking; secondary waste treatment; canister storage; and processed canister laydown area. The administration area includes offices, a reception area, multi-use rooms, a records vault, restrooms, lunchroom, storage, and mechanical and electrical equipment area. All of the necessary facilities to support waste retrieval will need to be built. After all waste canisters have been packaged, the facilities will be decontaminated and decommissioned.

The laydown area is a temporary pad where all canisters are held prior to shipping. The area has an underlying drainage system and storm-water retention pond. Once the canisters have been removed, the laydown area will be restored and re-vegetated.

\section{C-2.3 Description of Functions and Operations}

The functions and operations described below are used as a basis for developing the PLCC estimate and do not necessarily represent a method that will be used by Massachusetts.

C-2.3.1 Canister Retrieval. The process functional diagram in Figure C-3 illustrates the vault excavation, canister retricval, and site restoration processes, and indicates the acreage, excavation quantities, and the amount of restoration materials necessary for each facility size. The vault and stockpile areas will be cleared and grubbed. The earthen cap on the top of the vaults will be removed, and the material will be temporarily stockpiled on site. Most of the sideslope of the caps will remain intact and be used as a base for the access road on the vault.

After the cap is removed, operations will proceed cell-by-cell for canister retrieval. The roof panels will be lifted off by an overhead crane and placed in an adjacent, empty cell for disposal. Canisters also will be lifted out by an overhead crane and placed on waiting vehicles to be transported to the packaging facility. Sand formerly used as void fill will remain in the cells.

Closure of the cells and vaults will proceed contemporancously with canister retrieval. After the roof panels have been placed on the compacted sand backfill in an emptied cell, the rmaining void will be backfilled with the stockpiled cap material and with additional borrow material. Each cell will be sealed with a concrete cap. The concrete will be mixed onsite at the grout plant at the packaging facility. After the cells have been backfilled and sealed, a four-foot earthen cap will be placed over each excavated vault. The cap will be graded to the contours of the original cap and all disturbed areas will be restored.

C-2.3.2 Canister Packaging. The process functional diagram in Figure C-4 shows the canister receiving and packaging facilities process, as well as the material quantities and number of canisters for each facility size. All of the canisters will be brought from the waste retrieval area to the packaging facility and will remain unopened throughout processing. Canisters will be staged as needed at the truck receiving and washdown area and will be inspected for damage or deterioration, and assayed for radiologic integrity. It is assumed ad five percent of the canisters will not pass inspection. These $5 \%$ will be placed in overpack canisters. After the smaller canister is placed into the overpack canister, any remaining void and the top will be sealed with 
grout. Each canister, whether the original or the overpack, will be labelled and manifested. They 'will be transported to the laydown area and stacked in parallel rows, two wide and three high.

Secondary waste generated throughout the canister retrieval process and packaging includes contaminated personal protection equipment, wash water, and laboratory materials. This waste will be mixed with an equal volume of grout and placed in overpack canisters. Secondary waste canisters will be labelled, manifested and staged in the canister laydown area.

After completing retrieval operations, the packaging facility will be decontaminated and demolished, and site utilities will be decommissioned. Materials and equipment will be recycled or disposed appropriately. The site will be restored to conditions prior to waste retrieval.

\section{C-3 RETRIEVAL COST ESTIMATES}

The PLCC retrieval estimate was developed with the construction cost estimating program previously used for the operational disposal facilities. Labor, supplies, utilities, and material rates are the same as those used for the operational disposal facilities. Contractor overhead, administration, construction management, and contingencies are listed as separate items. For the applicable WBS elements, contractor's prolit is $25 \%$ of the construction and materials handling costs; contractor overhead is $20 \%$ of the construction costs; construction management is $20 \%$ of construction labor and material costs; and contingencies are $25 \%$ of administration and all construction costs. Construction activities are assumed to be 240 days per year, one-shift per day for the small facility, and two shifts per day for the other three facilities. Canister retrieval and processing will operate for two shifts per day.

\section{C-3.1 WBS-1 Vault Excavation and Canister Retrieval}

WBS-1 covers activities related to excavating the vaults and retrieving the canisters. This includes site development (utilities, access roads, and water), clearing and grubbing, excavating the vault cap, removing roof panels, and retrieving the waste canisters. These include all costs for equipment, labor, maintenance, supplies, and contractor's profit. Administration (FTE) consists of enginecring oversight, site and health physics monitoring, and QA/QC activitics. The FTEs during excavation and retrieval are 15,16, 24, and 34, for the small, medium, large, and extralarge facilities, respectively. The cost and time estimates for site preparation and excavation are based on current estimating factors from the construction industry. Similarly, the estimates for the removal of roof panels and canister retrieval assume present-day technologies and no unusual problems during retrieval operations. Roof panels weigh 13 tons each and are assumed to be removed and placed at 1 per hour. Canisters weigh approximately 10 tons each and it is assumed that one crew can retrieve and load 7.5 per day. For the larger facilities, more crews are needed to complete retrieval operations within the desired time frame. The small and medium facilities assume three retrieval crews and completion of retrieval operations in 1.76 years; the large facility assumes six retrieval crews and completion of retrieval operations in 2.78 years; and the extralarge facility assumes 16 retrieval crews and completinn of retrieval operations in 4.08 years. Activities such as backfilling the cells are concomitant with retrieval actions. 


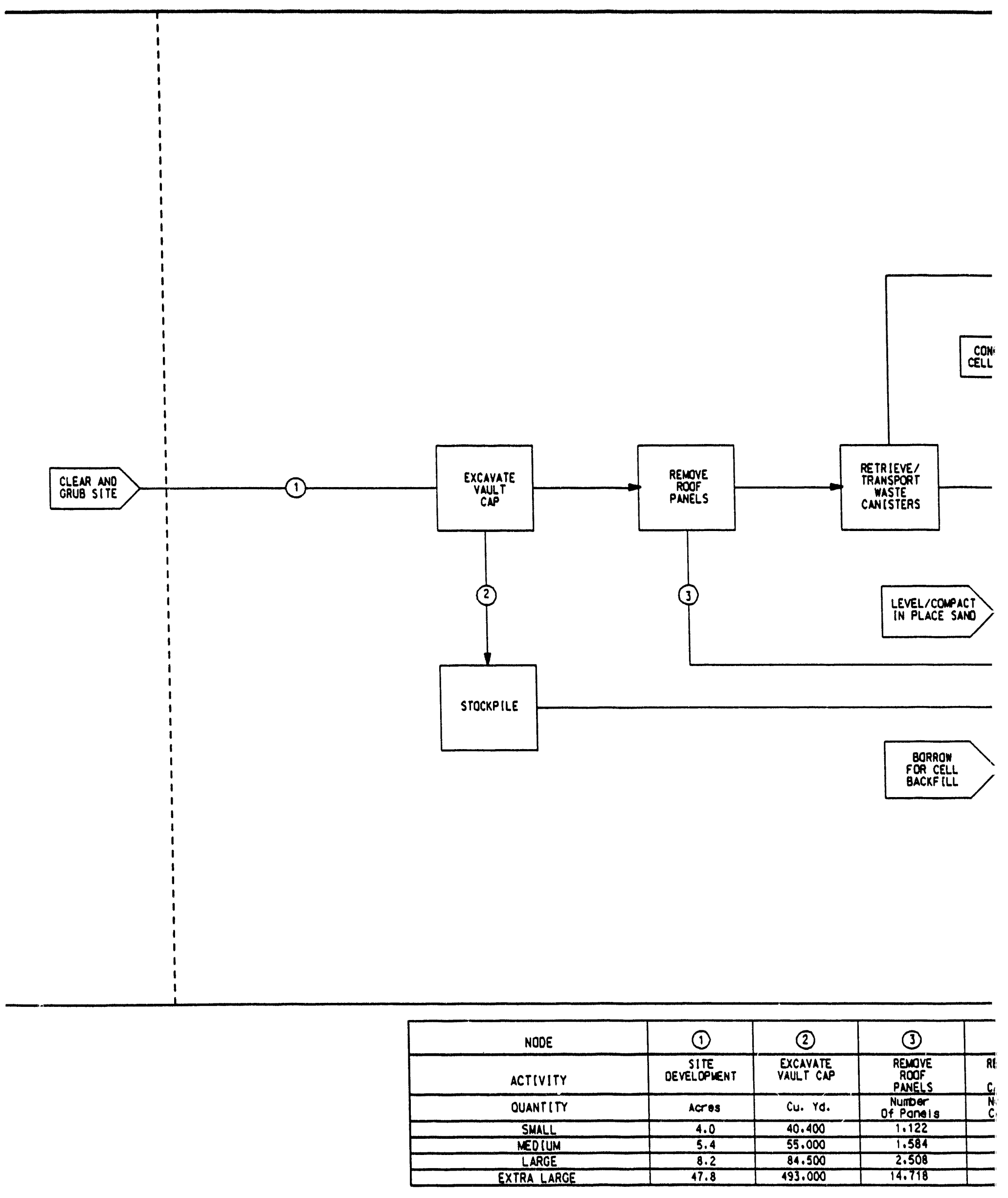

FIGURE C-3. PROCESS FUNCTIONAL DIAGRAM FOR VAUI: 


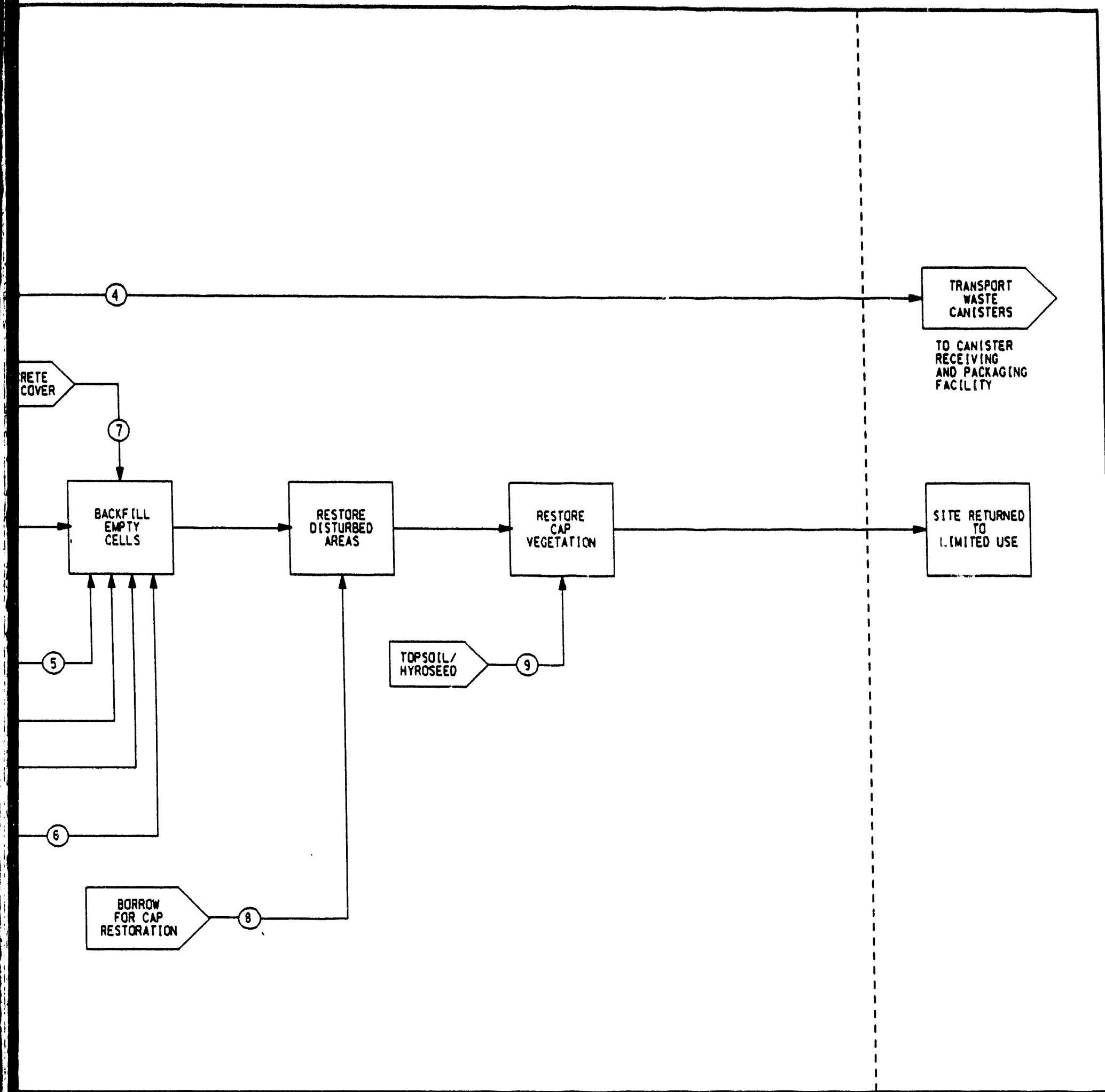

\begin{tabular}{|c|c|c|c|c|c|}
\hline (4) & (5) & (6) & (7) & (8) & (9) \\
\hline $\begin{array}{l}\text { TRIEYED } \\
\text { MSTE } \\
\text { IISTERS }\end{array}$ & $\begin{array}{c}\text { COMPACT } \\
\text { SAND }\end{array}$ & $\begin{array}{l}\text { BORROW FOA } \\
\text { CELL BACXFILL }\end{array}$ & $\begin{array}{l}\text { CONCRETE } \\
\text { CELL COVER }\end{array}$ & $\begin{array}{l}\text { RESTORE } \\
\text { DISTUREEO AREAS }\end{array}$ & $\begin{array}{l}\text { RESTORE CAP } \\
\text { VEGETATION }\end{array}$ \\
\hline $\begin{array}{l}\text { noer of } \\
\text { histers }\end{array}$ & Cu. Yo. & Cu. Yo. & Cu. Yo. & Cu. Yo. & Acros \\
\hline$\frac{9.537}{17.461}$ & $\frac{5.040}{7.10}$ & 4.794 & 3.170 & $\frac{13.200}{17.50}$ & 4.0 \\
\hline 13.464 & 7.110 & 8.808 & 4.470 & 17.650 & 5.4 \\
\hline 21.318 & 11.260 & 16.527 & 7.070 & 27.038 & 8.2 \\
\hline 25.103 & 66.060 & 99.888 & 41.480 & 139.860 & 47.8 \\
\hline
\end{tabular}




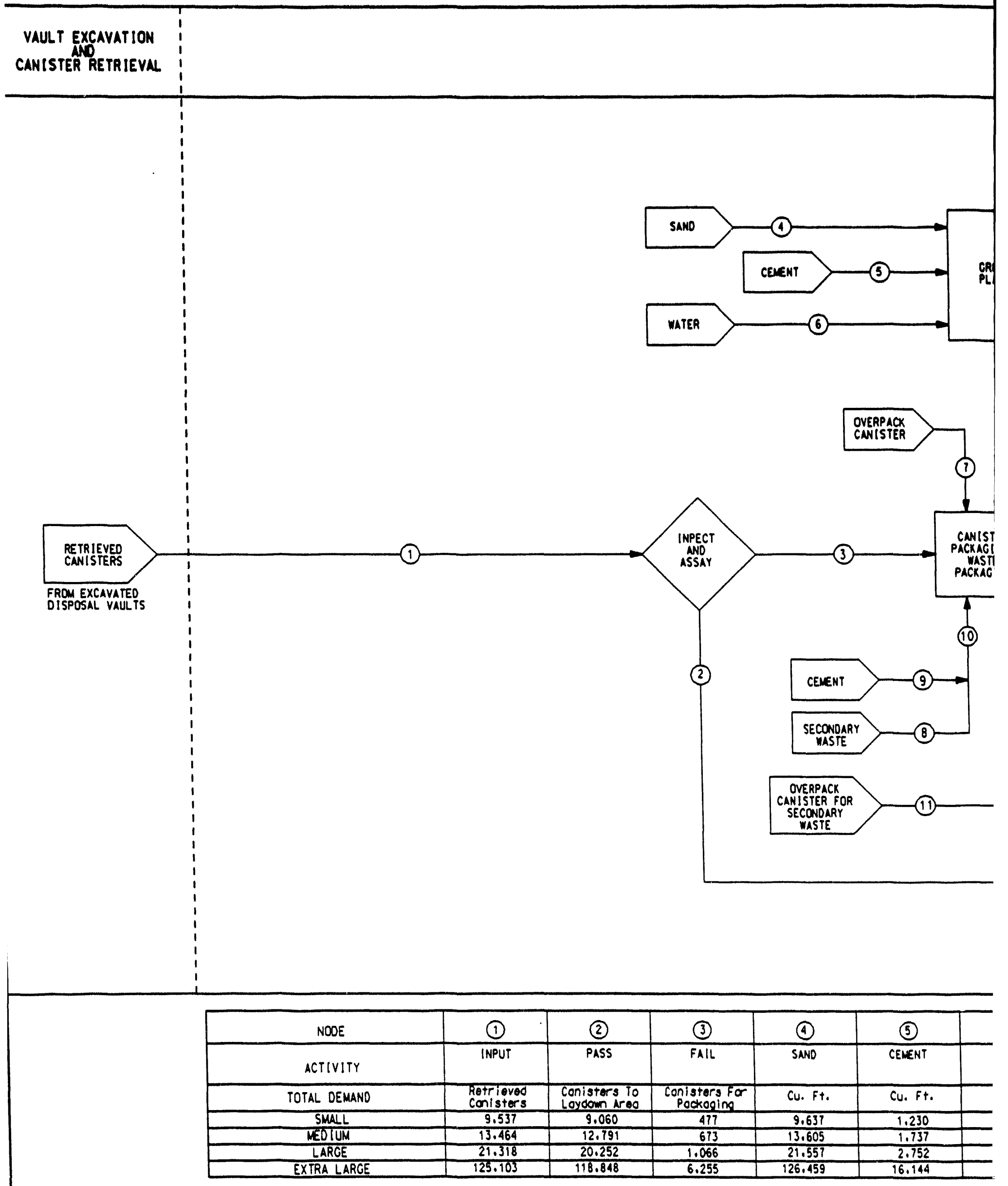




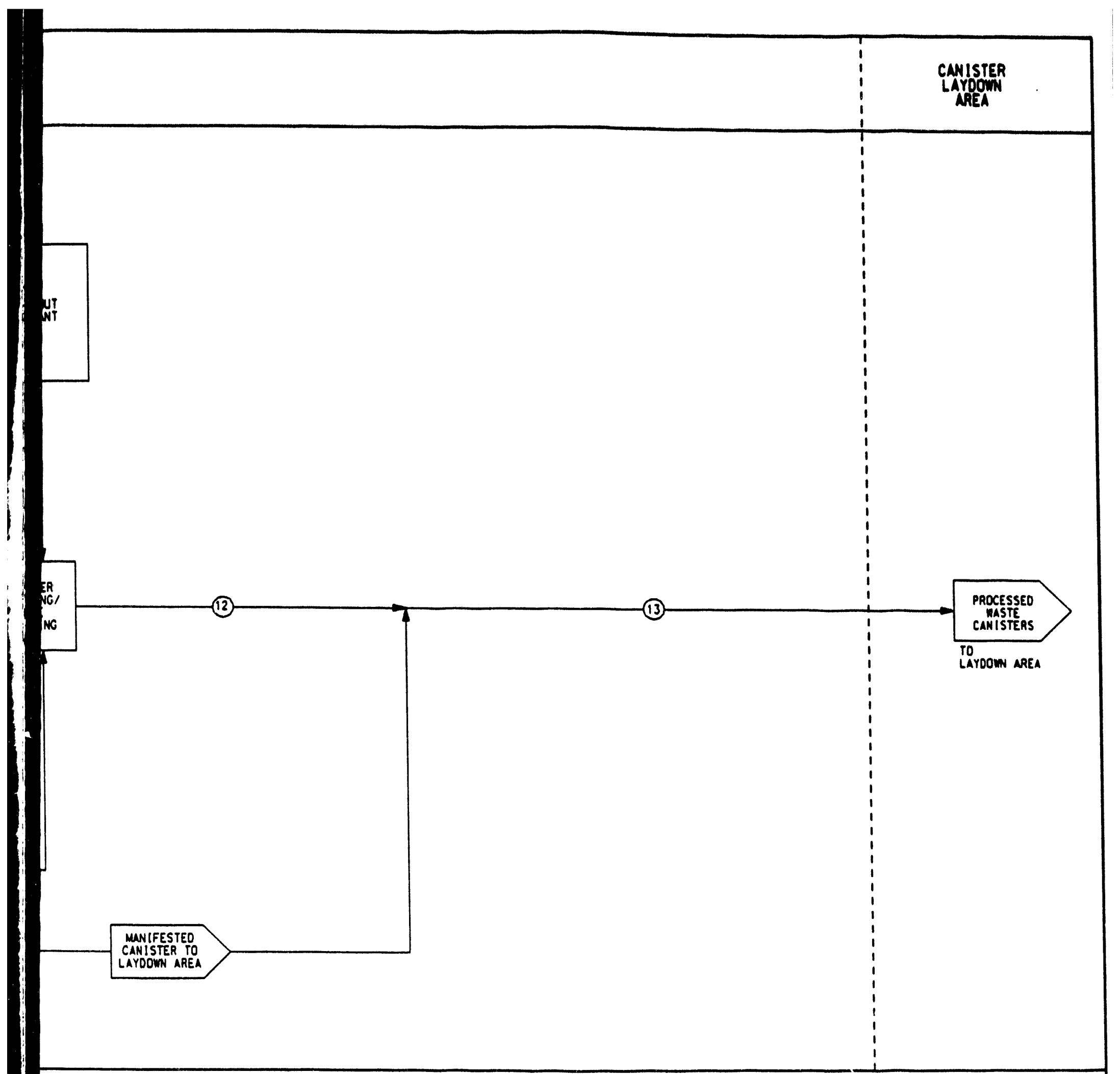

\begin{tabular}{|c|c|c|c|c|c|c|c|}
\hline (6) & (7) & (B) & (9) & (10) & (11) & (12) & (13) \\
\hline MATER & CANISTER & $\begin{array}{l}\text { SECONOARY } \\
\text { WASTE }\end{array}$ & $\begin{array}{l}\text { CENENT FOR } \\
\text { SECONOARY NASTE }\end{array}$ & $\begin{array}{c}\text { QUTPUT FOR } \\
\text { SECONDARY WASTE }\end{array}$ & $\begin{array}{l}\text { OVERPACK CANISTERS } \\
\text { FOR SECONDARY WASTE }\end{array}$ & $\begin{array}{l}\text { PROCESSED } \\
\text { CANISTERS }\end{array}$ & $\begin{array}{l}\text { CANISTERS FOR } \\
\text { SHIPMENT }\end{array}$ \\
\hline ollans & $\begin{array}{l}\text { Overpock } \\
\text { Conister }\end{array}$ & Cu. Ft. & Cu. Ft. & Cu. Ft. & Conister & Conister & Conister \\
\hline 6.885 & 477 & 11.902 & 11.902 & 23.804 & 153 & 630 & 9.690 \\
\hline 9.720 & 673 & 16.803 & 16.803 & 33.606 & 215 & 888 & 13.679 \\
\hline 5.400 & 1.066 & 26.606 & 26.606 & 53.210 & 341 & 1.407 & 29.659 \\
\hline 0.345 & 6.255 & 156.129 & 156.129 & 312.257 & 1.998 & 8.253 & 127.101 \\
\hline
\end{tabular}


Cost estimates for vault excavation and canister retricval were determined in the following manner. The necessary crew and equipment demands were determined for a unit amount of work: 100 acres for clearing and grubbing; 10,000 cubic yards for cap excavation; 100 pancls for the roof panel removal; 100 canisters for canister retrieval; 100 cells for cell backfill; 10,000 cubic yards for cap restoration; and 100 acres for site restoration. Once the equipment and labor demands were determined for a task, the quantity of materials to be moved were then multiplied by the hourly cost per unit of material for the equipment and crew to perform the task. For a small disposal vault, 9.537 canisters multiplied by the unit cost of canister retricval (\$345.68) equals $\$ 3,296,751$.

\section{C.3.2 WBS-2 Facility Construction}

The estimates for constructing the receiving and packaging facility includes the costs for site development, overhead, administration, contingencics, and construction management. The items of WBS-2 are for building a new waste-packaging facility, canister receiving and packaging area, enginecring and health physics laboratory, grout plant, canister laydown area, and haul road.

The cost estimates for facility construction use the same information for the operational disposal lacilities. The sizes of the different components of a front-end facility were determined for the new functions with emphasis on sizing the grout plant, the canister packaging and inspection areas, and the truck receiving and wash down areas. Due to the time frame allowed for completion of the retrieval activities and number of canisters to be processed, the small and medium facilities have two truck receiving bays, the medium facility has 4 truck receiving bays and the extra-large facility has $\mathbf{8}$ truck receiving bays. Fuel and utilities demands are also increased to account for the higher processing rates. Administration (FTE) burden is for project management. engineering, QAVQC controls, and security. The FTEs for the packaging facility construction are 10. 11, 12, and 19, for the small, medium, large and extra-large facilities, respectively.

The canister laydown area is configured as a rectangular pad comprised of a polyethylenecoated geofabric, 0.5 feet of sand and 0.5 fect of aggregate. Canisters are stacked 2 wide and 3 high, with 12-foot aisles and a 20-foot perimeter road. A stormwater retention pond designed for a maximum capacity of a 10-year, 24-hour storm is included in the laydown area cost estimate. The haul road from the canister retricval area is assumed to be one-quarter mile long for the small, medium, and large facilities and one-half mile long for the extra-large facility. The road is 40 feet wide and composed of eight inches of aggregate base and six inches of crushed gravel.

\section{C-3.3 WBS-3 Waste Packaging Operations}

The estimates for opcrations in WBS-3 include costs for administration, materials, utilities, supplies, and operations for processing the waste canisters after they have been retrieved. Operations expenditures include mechanical maintenance and equipment parts and are calculated at $7 \%$ of the capital costs. Administration costs are for site management and support; technical, engineering and QA/QC staff for canister procesing; and labor for the handling and transfer of processed canisters. Supplies, salaries and utilities are calculated on an annual basis and are given the same annual escalation factor as the canister retricval activities to allow enough time for 
complete canister retricval and processing. These escalation factors are 1.76 years for the small and medium facilities; 2.78 years for the large facility; and 4.08 years for the extra-large facility. Expenditures for sand, cement, and canisters are the total costs for the grout for sealing the overpack canisters, cement for processing the secondary waste, and all overpack canisters. Staffing demands are based on 2 shifts per day, 240 days per year. FTEs are 29, 30, 44, and 89, for the small, medium, large, and extra-large facilities, respectively.

\section{C.3.4 WBS-4 Site Closure}

Closure costs are for decommissioning the packaging facility, which includes the administration area, canister receiving and packaging area, and the grout plant. Closure costs for the excavated cells, disposal of the cell materials, and site restoration - although concomitant with retrieval operations - are calculated as separate costs and also presented in WBS-4. This includes compacting the sand backfill, placing roof pancls into the emptied cells, filling remaining cell void, installing the concrete seal, importing additional cap matcrials, removing utilities, and revegetation of the site.

As with the vault excavation and canister retricval costs, the site closure costs were developed by determining crew and equipment demands based on a unit activity of work. Since the roof panels were removed and placed as one task but considered both as a retrieva! and closure activity, one-half of the cost is applied during excavation and one-half of the cost is applied during closure. Also, sand backfill remaining in the cells after canister retrieval must be levelled and compacted before placing the roof panels. The total cost for placing the roof panels is the sum of these two items. Excavated cap materials are put into the cells as backfill. An additional amount of material is required to completely fill the cells. The estimate for the backfill includes costs for moving the cap materials and imported borrow material. A one-foot-thick section of concrete is used to scal each eell. The cost of the concrete assumes that the onsite grout plant can be used for mixing concrete. Site restoration includes four feet of borrow material, and replacing the topsoil stockpiled from the cap at the beginning of the excavation phase. Restoration of site vegetation is by reseeding the area with grasses, mulch, and tertilizer. The FTE burden is for engineering oversight, technical and QAVC controls, site monitoring and security. Construction management, contractors profit, and contingencies are the same as WBS-1 and WBS-2. The FTEs are 13,14, 19, and 28, for the small, medium, large, and extra-large facilities, respectively. 


\section{C-4 CONCLUSIONS}

The PLCC estimates are summarized in Table C-2. Total costs are from $\$ 47,919,000$ to $\$ 274,421,000$. The unit rates range from $\$ 90$ to $\$ 40$ per cubic foot based on the volume of the retrieved waste and processed secondary wastes. The line graph of Figure C-5 compares the total expenditures and the unit rates for processing the retrieved wastes. The bar graph in Figure C-5 plots the costs of each element of the PLCC estimate against the unit rate per canister (\$4,950 to $\$ 2,160)$. The costs of retricving LLRW from a disposal facility may vary significantly from these cost estinates due to a number of factors, such as markups, changes in labor or material rates, regulatory mandates, and available future technologies. Therefore, these cstimates represent a broad-based analysis to be used only as guidance in evaluating LLRW management options.

The highest costs of the retrieval process is the vault excavation, canister retrieval and construction of the new canister packaging facilitics. These costs are about $66 \%$ of the total estimated retricval expenditures. As with the operational disposal facilities' PLCCs, the unit rate decreases significantly between the facility sizes due to the economy of scale for the costs distributed over the entire volume of processed materials.

Assuming institutional control ceases before the long-lived LLRW decays to desirable levels, the unit rate of disposal in 1994 dollars will increase by an average of $\$ 68$ per cubic foot for the four sizes of disposal facilitics. Although the estimated unit rate for the retrieval PLCC is about one-fifth of the original disposal estimate, the total estimated unit rate for retrieval could be much higher if the cost of transportation and redisposal of the wastes were considered. However, these costs were not included in the PLCC estimate since the redisposal scenario cannot be defined at this time.

Table C-2. Summary of PLCC estimates for long-lived LLRW retrieval.

\begin{tabular}{|c|c|c|c|c|}
\hline $\begin{array}{l}\text { Work Breakdown } \\
\text { Structure Element }\end{array}$ & Small & Medium & Large & Extra-large \\
\hline Excavation and Canister Removal & $\$ 11,544,000$ & $\$ 15,144,000$ & $\$ 26,396,000$ & $\$ 127,174,000$ \\
\hline Canister Packaging Facilitics & $\$ 20,820,000$ & $\$ 21,589,000$ & $\$ 28,228,000$ & $\$ 51,347,000$ \\
\hline Canister Packaging Operations & $\$ 7,351,000$ & $\$ 8,840,000$ & $\$ 18,090,000$ & $\$ 63,799,000$ \\
\hline Site Closure & $\$ 8,205,000$ & $\$ 8,935,(000)$ & $\$ 12,510,000$ & $\$ 32,101,000$ \\
\hline Total Retrieval Costs & $\$ 47,920,000$ & $\$ 54,508,000$ & $\$ 85,224,000$ & $\$ 274,421,000$ \\
\hline Unit cost per canister ${ }^{1}$ & $\$ 4,950$ & $\$ 3,980$ & $\$ 3,930$ & $\$ 2,160$ \\
\hline Unit cost per $\mathrm{ft}^{3}$ waste $\mathrm{e}^{2}$ & $\$ 90$ & $\$ 70$ & $\$ 70$ & $\$$ \\
\hline \multicolumn{5}{|c|}{$\begin{array}{l}\text { 1. Number of canisters includes retrieved canisters and processed secondary waste: } \\
\text { small }-9,690 \text {; medium }-13,679 \text {; large }-21,659 \text {; extra-large }-127,101\end{array}$} \\
\hline \multicolumn{5}{|c|}{$\begin{array}{l}\text { 2. Waste } v r^{\cdot} \text { 'me includes retrieved and secondary wastes: } \\
\text { small } \cdot 348,804 \mathrm{ft}^{3} ; \text { medium }-783,606 \mathrm{ft}^{3} ; \text { large } \cdot 1,253,210 \mathrm{ft}^{3} \text {; extra-large } \cdot 7,312,257 \mathrm{ft}^{3} \text {. }\end{array}$} \\
\hline
\end{tabular}




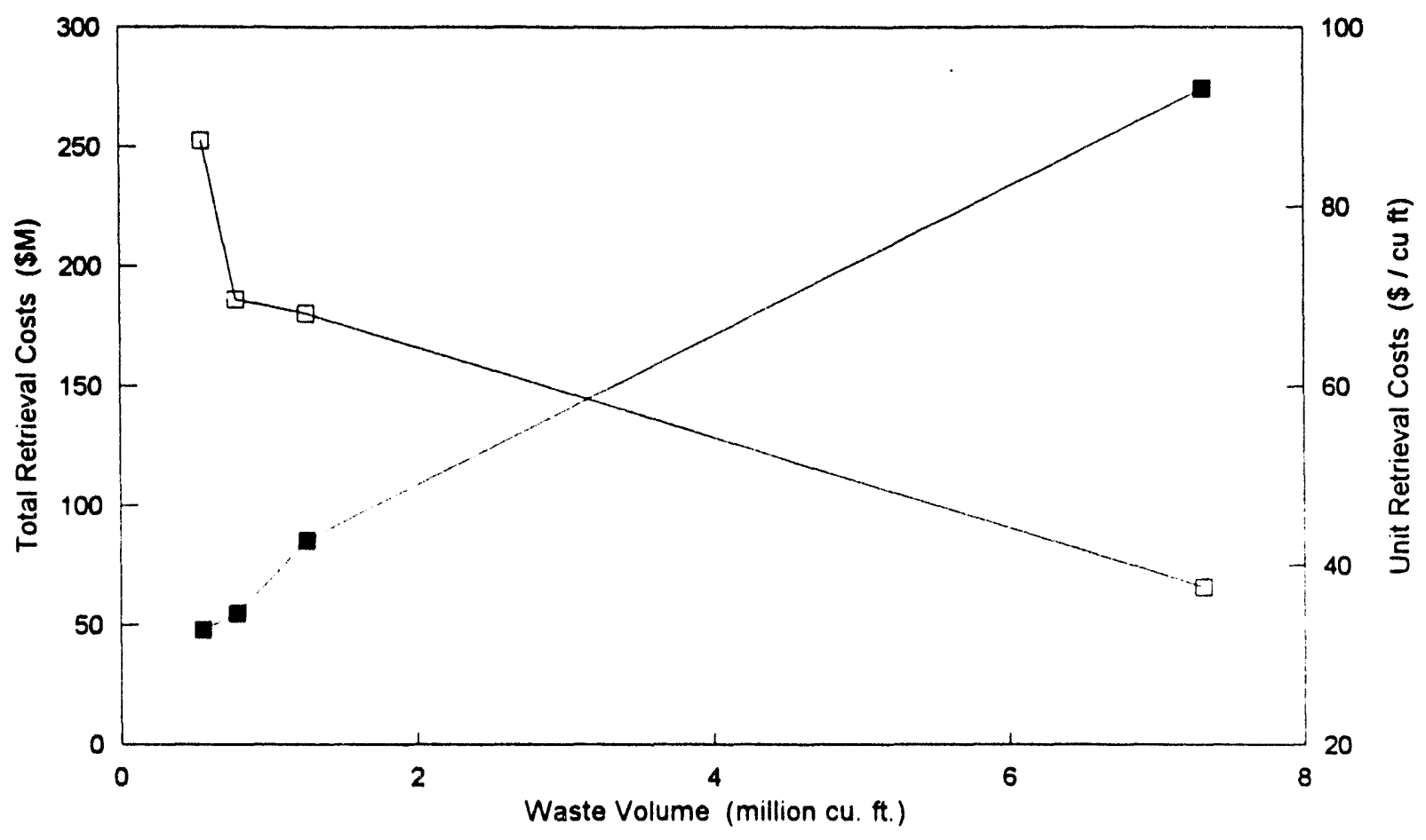

- Retrieval: Total Cost $\quad \exists$ Retrieval: Unit Cost

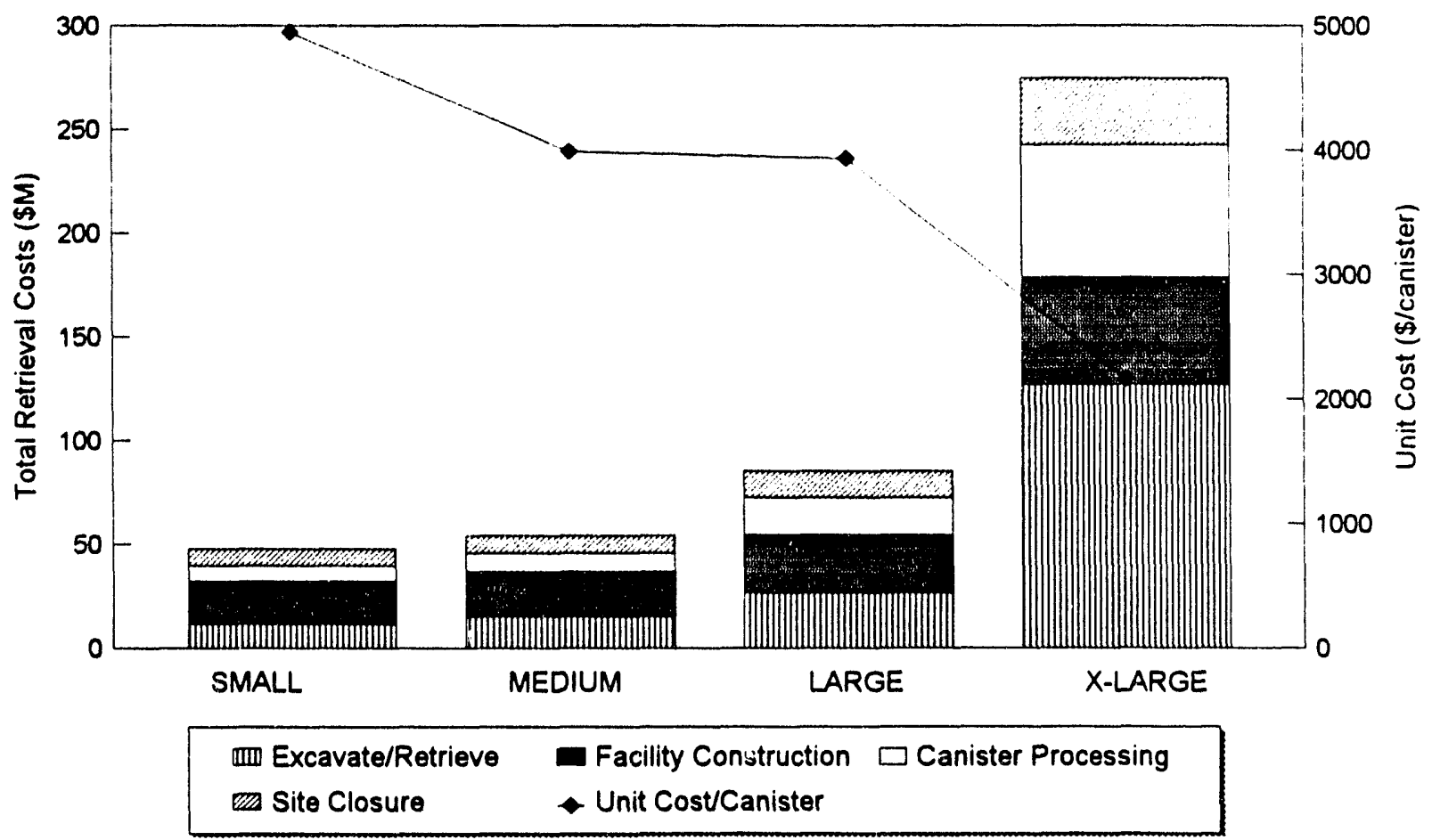

Figure C.5. PLCC retrieval cost comparisons. 

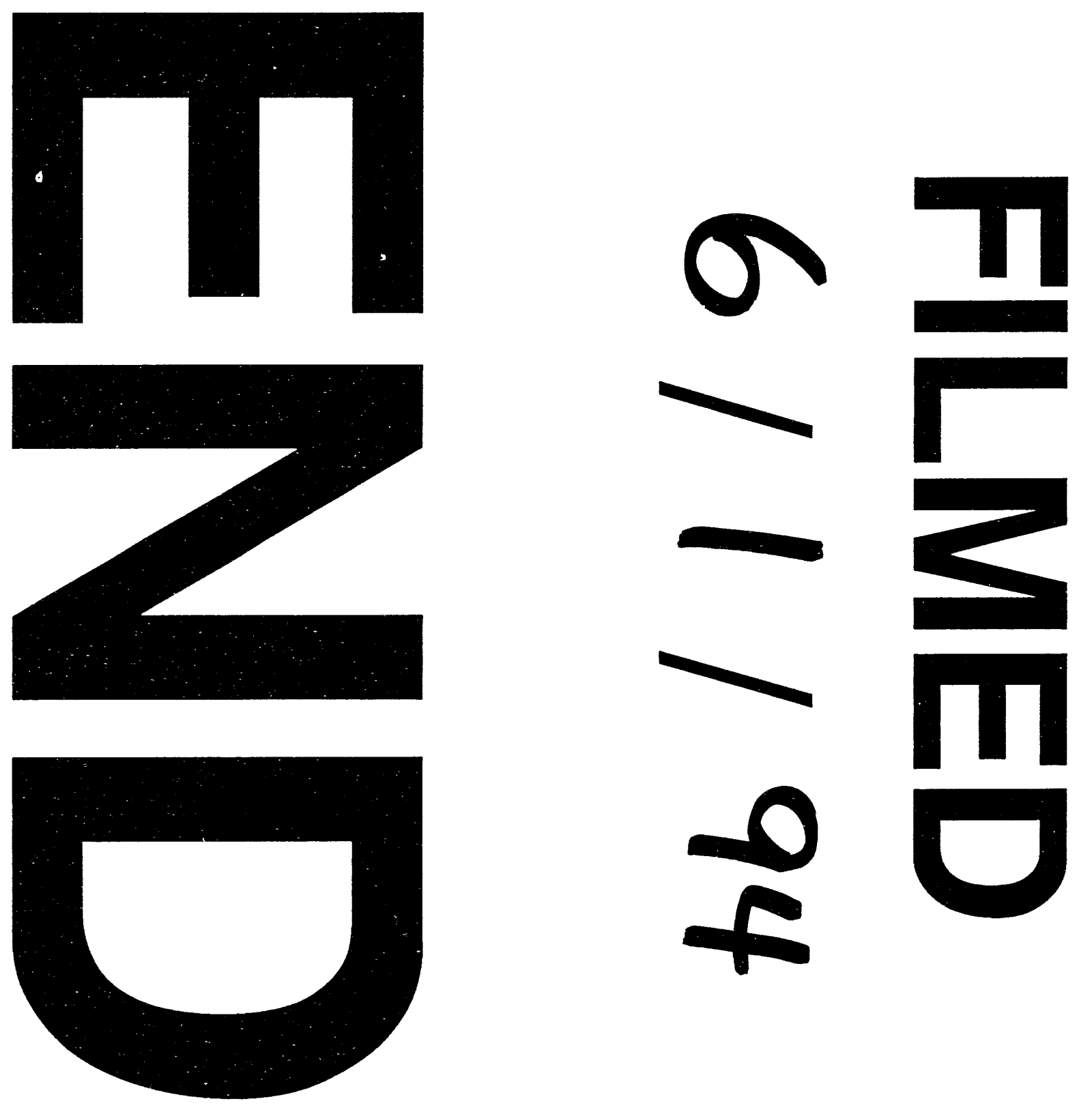

$\stackrel{0}{f}$
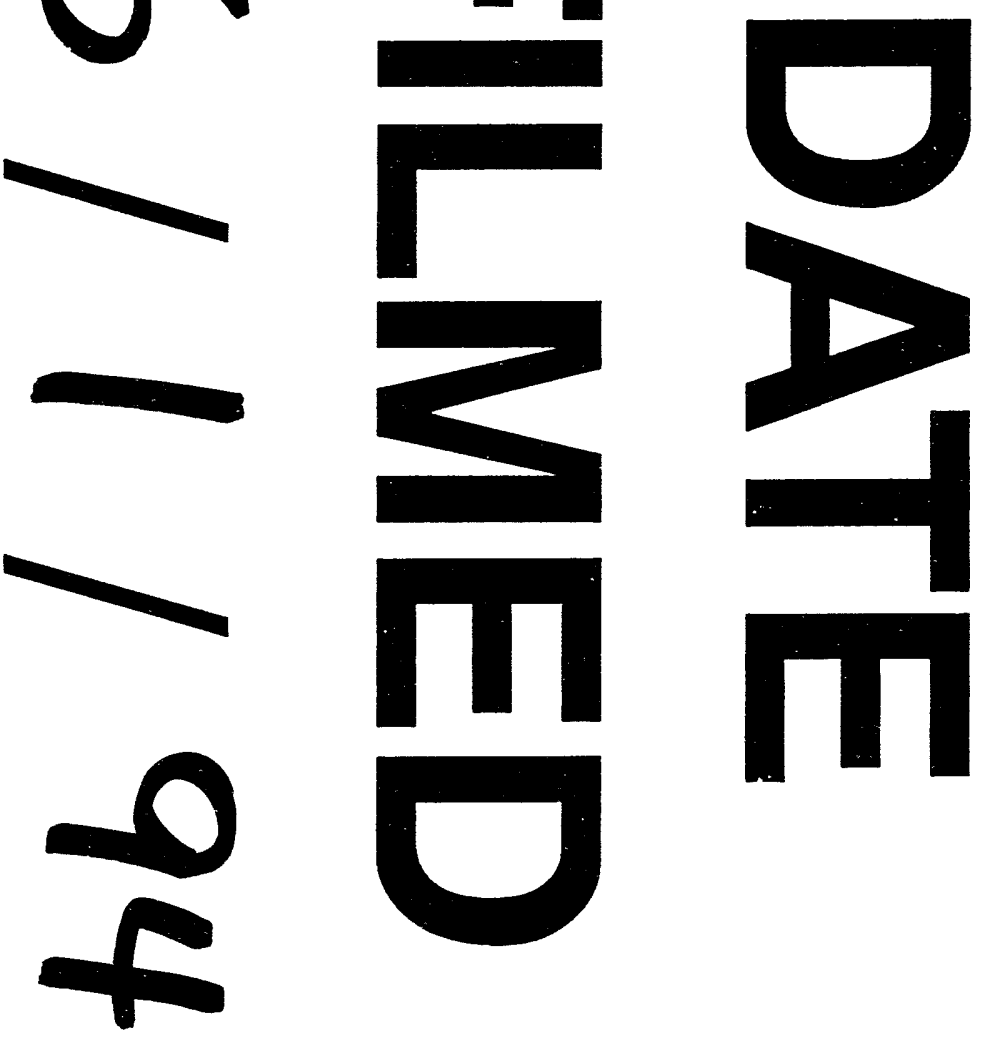
